\title{
THE HISTORY OF COLLECTING GIORGIONE IN AMERICA - AN OUTLINE
}

\begin{abstract}
Klára Garas was called upon in 1993 to write about the paintings by or attributed to Giorgione preserved in America. The manuscript was completed, but it has been never published. The author passed the article to the Acta Historiae Artium shortly before her death (26 June 2017), and it is published now only with small technical amendments.

Keywords: Giorgione, art collecting in America, Italian Renaissance
\end{abstract}

The history of art collecting in America, especially of Italian Renaissance paintings can only be roughly outlined here and only in connection with one of its leading masters, Giorgione. ${ }^{1}$ In his catalogue of the exhibition Raphael in America (Washington, 1983), D. A. Brown gives us a valuable summary of the different trends of development, which can also serve as background in relation to Giorgione. ${ }^{2}$ Art collecting started at the very beginning, when, at the end of the eighteenth century, amid the struggles for independence, American culture and art was built upon its own fundaments. It was not an easy task for the founding fathers to find the right way, and so it is not surprising that Thomas Jefferson - himself an ardent art lover and a collector - should write to his friend Adams: "The age of painting and sculpture has not arrived in this country and I hope it will not arrive soon." It is in the same sense that Benjamin Franklin claims that "... the invention of a machine or the improvement of an implement, is of more importance, than a masterpiece by Raphael". ${ }^{3}$ In spite of these statements and similar others, which represent part of the general

\footnotetext{
* Klára Garas (1919-2017), art historian, member of the Hungarian Academy of Sciences, former director of the Museum of Fine Arts, Budapest
}

atmosphere, there seems to have been a certain interest in works of art coming from Italy and elsewhere since about the 1780s. We even hear of an important shipment of Venetian paintings sent to Philadelphia by a famous English collector and resident in Venice (1774-1790) for the considerable sum of 9,000 Zecchini. ${ }^{4}$ What it might have contained and where the pictures got to, is unfortunately unknown. In the first half of the nineteenth century there were already collections, and regular exhibitions in Boston, New York, Philadelphia, Baltimore, etc. presenting also some Venetian paintings.

The first Americans known to have owned works ascribed to Giorgione were painters in the late eighteenth and the early nineteenth century, for instance John Trumbull and Benjamin West. But their collections were formed and also sold in Europe. At the London sale of John Trumbull's (1756-1843) collection in 1797 a Holy Family by Giorgione was listed, a painting bought in Paris in 1795 from M. le Rouge, which until now could not be traced or identified. Benjamin West (1738-1820), president of the English Royal Academy, was in possession of a little painting in London, thought to be original by Giorgione and considered a portrait of Gaston de Foix in France (Fig. 1), where it was bought for England. After the sale of Benjamin West's collection in 1820 (at Christie's, No. 62), it 
came finally into the possession of the National Gallery in London and is regarded today by most experts as a school work, a copy after the S. Liberale in Giorgione's altarpiece in Castelfranco. ${ }^{5}$

The fascinating early story of collecting Italian art in the United States, and the interest in Giorgione is closely connected with the activity of James Jackson Jarves (1818-1888). Born in Boston, Jarves went to Europe after a rather adventurous life and wanderings, settled in 1852 in Florence, where he acted temporarily as American vice-consul. He began there to write about art and build up a collection of Italian paintings. His experiences and remarks in his Old Masters of Italy (New York, 1861) or his Art Studies. The Old Masters of Italy (New York, 1861) are extremely illuminating on the ways of collecting in his time. He tells about the risks and difficulties, the tricks and mischief of dealers "that would almost appear fabulous to the inexperienced". Though he finds that "the taste of collecting is rapidly developing in America", he draws attention to the fact that "old masters are almost a byword of doubt and contempt in America owing to the influences of cheap copies and pseudo originals of no artistic value whatsoever". ${ }^{6}$ The fate of his own collection was certainly determined by these difficulties. He proposed to make the "nucleus of a Free Gallery in one of our large cities," thus he took his treasure of about 145 paintings in 1859 from Europe back to America. They were put on show first in New York $(1860,1863)$, but he found no interest for them. Heavily in debt, Jarves gave them on loan, and then sold them for 22,000 dollars to the Yale University (New Haven), where they are kept in the Gallery until this day, presenting an exceptional selection of early Italian art. He had no more luck with his second collection, formed afterwards: a part of this was finally (1884) sold to L. E. Holden and went to the Museum of Art in Cleveland. ${ }^{7}$ Among the mostly fifteenth-sixteenth-century Italian paintings owned by Jarves, there were, according to the old inventories and contemporary reports, three works ascribed to Giorgione. One of them, the Circumcision at the Yale University Gallery (Fig. 2) is still considered today to be closely related to the master, or to his pupil Titian. This rather badly ruined panel with a composition of half figures seems to have been acquired in the years 1852-1859 during Jarves' stay in Italy. ${ }^{8}$ Another painting, with three half-figures, called Andrea Gritti and His Sisters, quoted in the Jarves' papers and inventories as by Giorgione (Yale University Gallery, Nr. 1871.96) is a work of a sixteenth-century Venetian painter, according to B. Berenson, eventually S. Flo- rigerio. Jarves' third Giorgione, which never came to America and was not known until now, can be identified on the basis of some hitherto unnoticed reports. Its story is connected with a lawsuit. In 1865 Jarves accused the French art dealer, M. Moreau in Paris, that the three paintings he had bought from him, allegedly by Leonardo, Luini and Giorgione were not really originals and in a very bad state of preservation. He lost his case as it was proved that he had ample occasion to thoroughly examine the paintings before buying them. The Revue Universelle des Arts in Paris relates the case in detail in 1866, and thus we learn that the

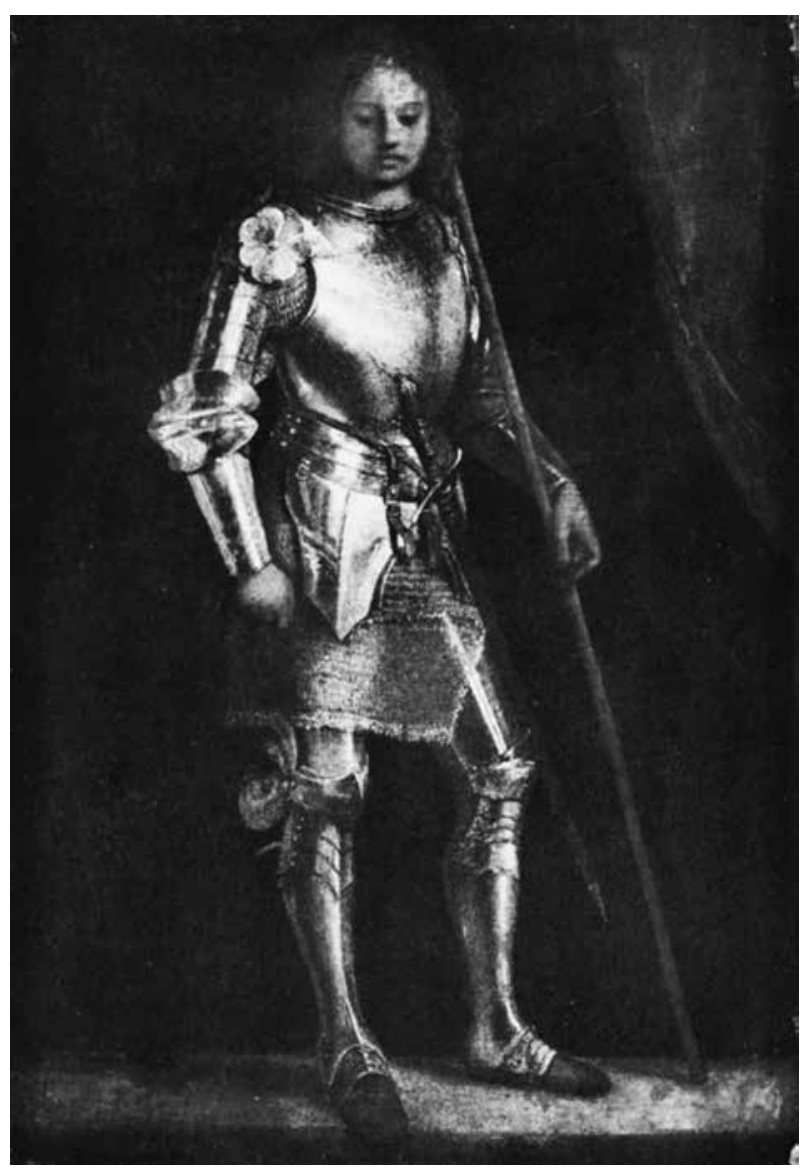

Fig. 1. Gaston de Foix; panel, $39 \times 26 \mathrm{~cm}$; London, National Gallery

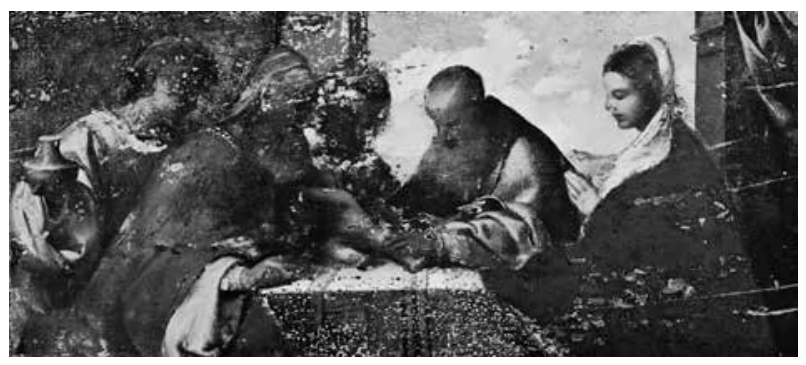

Fig. 2. Circumcision; panel, $36.7 \times 79.3 \mathrm{~cm}$; New Haven, Yale 
piece bought by Jarves as a piece by Giorgione represented Malatesta Rimini and His Mistress Receiving the Pope's Legate. It was supposed to come from the Grimani Palace in Venice (1824). ${ }^{9}$ After his failure with the law, Jarves sold this picture, which by 1881 was in the possession of William Neville Abdy, and after 1911 in the Benson collection in England. Owned by Guy Benson and called Lovers and the Pilgrim (Fig. 3) it is usually quoted in old and recent Giorgione literature as by Giorgione and his assistants, that is as a problematic work closely related to Giorgione's style and conceptions. ${ }^{10}$

At about the same time the Jarves collection came to life, another collector Jarves thought highly of, the painter Miner K. Kellog (1814-1884) in Cleveland had formed a little gallery of pictures, among others a few from the Venetian school, attributed to Titian, Tiepolo and also Giorgione. The last one - now unknown - was a portrait of an artist. ${ }^{11}$ These seem to be isolated examples, because for a long time in the nineteenth century, those who had the means to spend on art, to build big houses and decorate them adequately were mostly interested in American painting or contemporary painting of the European continent. It was only after the Civil War, the general boom and the creation of real wealth that the interest in luxury, in the splendour of European past and culture became dominant in some strata of American society. The leaders of finances and industry soon found out that the great figures of Italian Renaissance presented, with their outstanding personalities and dominance in so many fields of existence, a model worth of esteem and imitation. Building and collecting art soon became a fashion among the new millionaires as they were getting more and more into competition to prove their importance and power. Almost all of them, the Widener, Havemeyer, Johnson, Walters, Altmann, etc. families excelled in creating collections, buying more and more paintings and sculptures from Europe.

One of the most eminent collectors of Renaissance art in nineteenth-century America was Isabella Stewart Gardner (1840-1924) from Boston. Inheriting a large fortune at the death of her father (1891), she was able to pursue her passion and interest in the arts, developed in contact with the great painters of her country, John Singer Sargent and James McNeill Whistler, and during her travels in Europe. With the continuous help of her protégé and friend, Bernard Berenson (18651959), then the leading expert on Italian painting, she made significant purchases all over Europe, founding in her home at Fenway Court, Boston a unique cen-

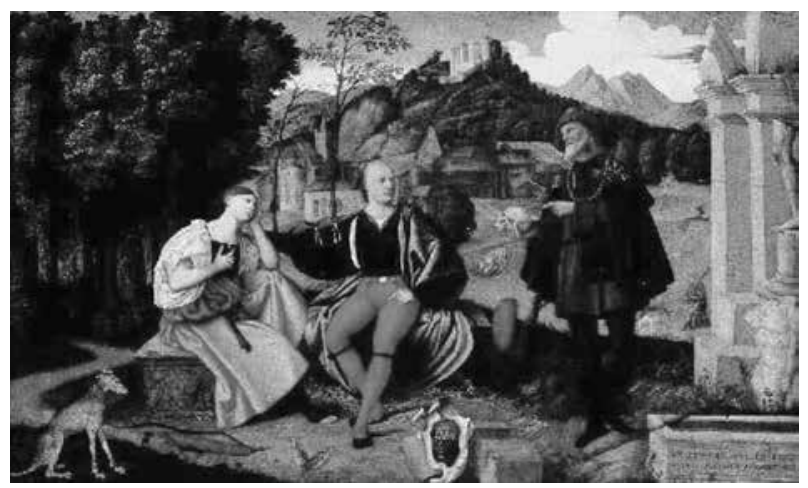

Fig. 3. A Pair of Lovers and a Pilgrim in Landscape; canvas, $50.5 \times 81 \mathrm{~cm}$

tre of Italian culture. Very fond of Venice, she let her palace be designed in Venetian style and made efforts to collect the best of Venetian art of the golden age. ${ }^{12}$ Sometime in 1896 she heard the news that "one of the greatest rarities of Italian painting, a Giorgione" was said to be for sale. As by then she already owned works by Titian, but no Giorgione's, she was very keen to acquire that painting, the Christ Bearing the Cross, from Count Zileri dal Verme at Vicenza. Her adviser, Bernard Berenson thought it to be an original work by the master and arranged the transaction in 1898 for the sum of 6,000 Lire. There were serious difficulties about the deal. The deceased Count Zileri left the painting first to the city of Vicenza, and then, changing his will, to his family. After some hesitation the heirs sold it secretly to Berenson, putting in its place a copy made at the cost of the future owner - as was the practice in such cases ever since the sixteenth century in Italy. Soon afterwards, acting against the law, the original was smuggled out of the country, a circumstance which caused later (1906) a most troublesome lawsuit against Berenson. ${ }^{13}$ Nevertheless, the Christ got to America and remained in Boston, in the Isabella Stewart Gardner Museum, where it is still considered by most of the experts to be an early work by Giorgione (Fig. 14). With her wish to purchase another Giorgione, the mistress of Fenway Court had less success. She dreamed of buying Giorgione's masterpiece from the Giovanelli family in Venice. But in spite of all the efforts made by Berenson, this proved impossible, because - as Berenson explained (1897) - the owner, Count Giovanelli was extremely rich and a great patriot, who refused downright to sell it abroad. In fact the Tempesta, one of the few really authentic works by Giorgione, was bought in the end by the Gallerie dell'Accademia in Venice and is still one of its greatest treasures. 
To acquire paintings by Giorgione was in any case an extremely difficult task, an experience soon shared by other American collectors of the time. Benjamin Altman from New York, for instance, bought at the advice of Berenson and with the help of Joseph Duveen (1912-1913) a beautiful Portrait of a Man as a work by Giorgione (Fig. 4). Though doubtful about the attribution when the picture first appeared at the New Gallery exhibition in London (1895), Berenson ascribed it to Giorgione ever since 1912, stating that "I am ready to stake all my reputation on its being by Giorgione". But this became a much contested opinion, and the painting in the Metropolitan Museum in New York is nowadays generally considered to be an early portrait by Titian. ${ }^{14}$ Its provenance from the collection of Walter Savage Landor, Florence (until 1864) and eventually from the Grimani Palace in Venice unfortunately gives no solid clue to its author or to the person represented. It belongs to that much discussed group of works, which were attributed in the past to Giorgione, but have been connected by later studies with the oeuvre of Titian. Changes in the interpretation of Giorgione, the modification of opinions concerning his style and development affected almost all the paintings that came under his name to America in the last decades of the nineteenth and the first quarter of the twentieth century. The controversy in the distinction of Giorgione and Titian, the insecurity especially in regard to portraiture has led to many changes in the previous attributions. The fascinating Portrait of a Man with Red Cap in the Frick collection, New York (Fig. 5), for instance was accepted by scholars (L. Coletti, 1955) as painted by Giorgione. Before it came into the possession of Henry Clay Frick in 1916, with its earlier owners - Paul Methuen, John Rogers, E. Wilson Edgell and Hugh Lane in England -, it figured alternately as a work by Giorgione or Titian. Recent research (A. Morassi, H. Tietze, F. Valcanover, P. Zampetto, R. Pallucchini, etc.) classifies it unanimously as a work by Titian from around $1515 .{ }^{15}$ It is a somewhat similar situation as with another portrait, the male half figure with Venetian background view in the National Gallery in Washington (Fig. 25). Previously it was listed as a Portrait of a Lawyer by Giorgione at the sale of William Graham's collection (1886, Christie's) in London, as by B. Licinio in 1895 in the collection of Henry Doetsch in London, and again as by Giorgione in 1897 with George Kemp, Lord Rochdale at Beechwood Hall. Acquired by Sir Joseph Duveen, it was sold to Henry Goldman, New York in 1922 for 125,000 dollars as an important work by Tit-

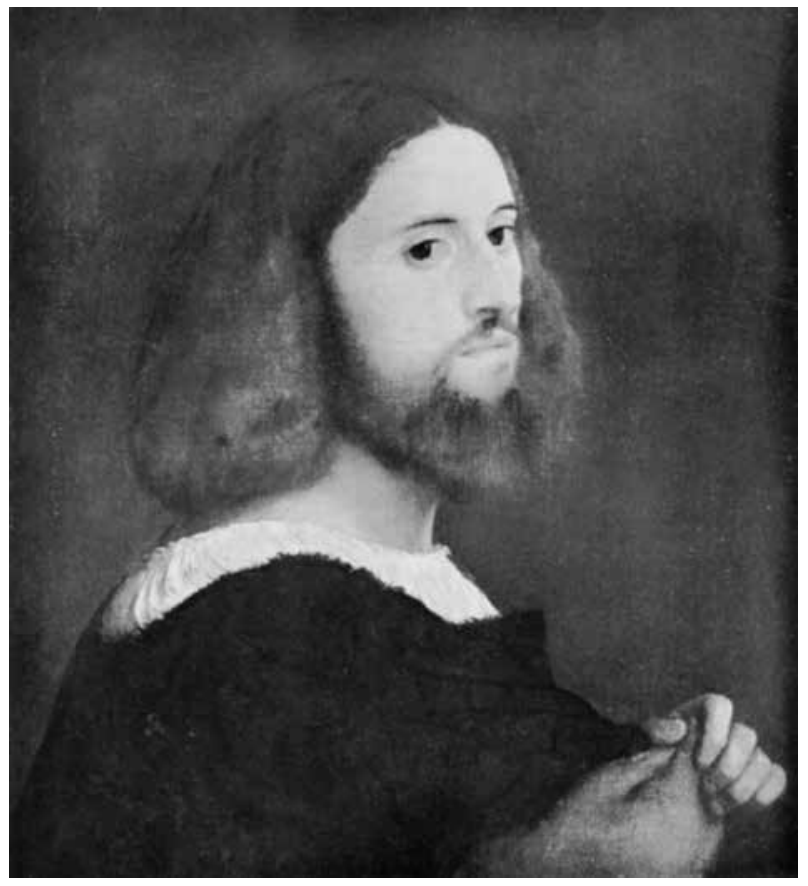

Fig. 4. Tiziano: Portrait of a Man; canvas, $50.2 \times 45.1 \mathrm{~cm}$; New York, Metropolitan Museum of Art

ian. ${ }^{16}$ Though this latter attribution prevails in later publications, the painting's condition as revealed by X-ray analysis and restoration, several stylistic features as well as the eventual earlier provenance closely connect it, in the opinion of a number of experts, with authentic late works by Giorgione. We also have to

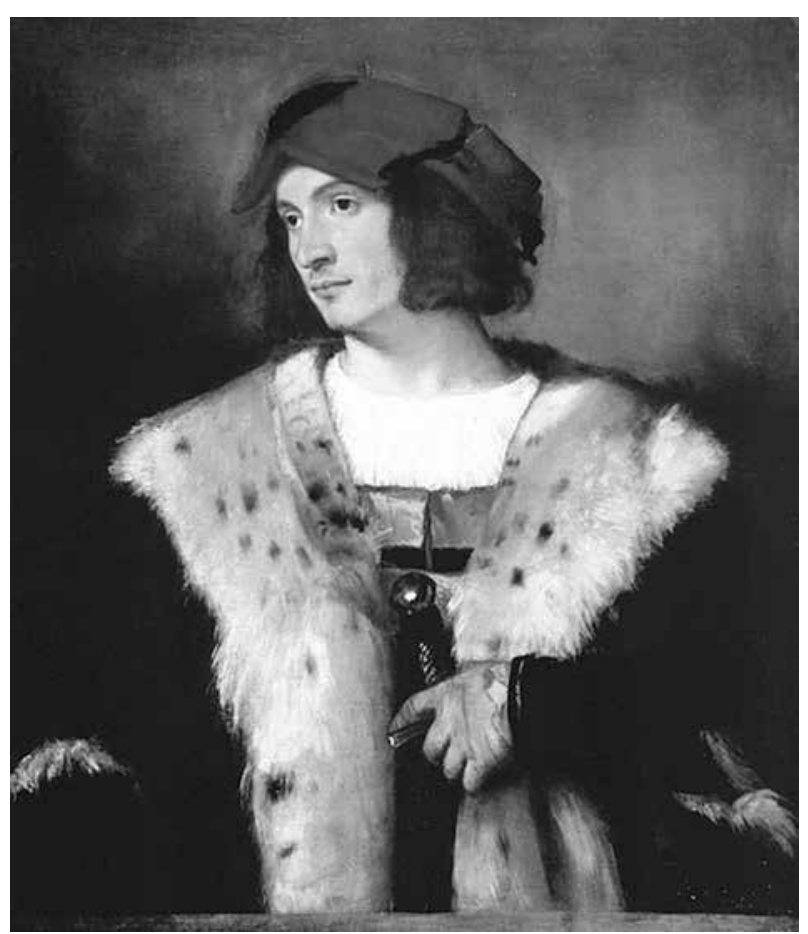

Fig. 5. Tiziano: Man with a Red Cap; canvas, $82.2 \times 71.1 \mathrm{~cm}$; New York, Frick Collection 
mention in this context the Portrait of a Man (Fig. 6) that was acquired by Jules Bache (1881-1944) in New York, equally through Duveen as a presumed work by Giorgione. In a bad state of preservation it is now in the Norton Simon Museum in Pasadena. Ever since it turned up in Vienna in 1922 it has tentatively been ascribed by a number of scholars (W. Suida, R. Pallucchini, F. Valcanover, P. Zampetti, etc.) to Titian. ${ }^{17}$

In most of the transactions dealt with above, a prominent person of the period, the art dealer Joseph Duveen played a decisive role. After the First World War, the conditions, structure and volume of American art collecting have changed fundamentally. The United States became more or less the centre and main goal of the art market with an almost unlimited demand for art treasures from the continent. The new generation of enormously wealthy collectors could not only afford to purchase the very best, but to form with purpose, taste and expert assistance really important collections and to found and enrich with them public institutions as well as museums. The most important art galleries and art sales houses soon settled in the States, chiefly on the East Coast, and the leading authorities in art, the best art historians - mainly from Germany and England - became active in America. A great part of the most valuable acquisitions in this period was brought in by Joseph Duveen (1869-1939), head of a great international firm. "The most spectacular art dealer of all time" - as his biographer, S. N. Behrman put it - "noticed that Europe had plenty of art and America had plenty of money." 18 So besides his establishments in London and Paris, he entered into business also in New York and soon was engaged in acting for the major art collectors in America. His most important clients were the millionaires Julius Bache, Henry Clay Frick, Benjamin Altman, Joseph E. Widener, Andrew Mellon, John D. Rockefeller, J. Pierpont Morgan, Samuel H. Kress, etc. Between the two world wars it was through him that the most outstanding works of art went from Europe to the United States; it is said that about 75 percent of the best Italian paintings were acquired through his mediation. Duveen had no special predilection for one or the other school or master; what he was really interested in was high quality, exceptional value and a special attraction to his important customers. A painter like Giorgione certainly ranked foremost in this respect, as his works were extremely rare to come by. Only very few existed in the major European museums, they only turned up exceptionally on the art market or with private owners. They were almost always accompanied by contro-

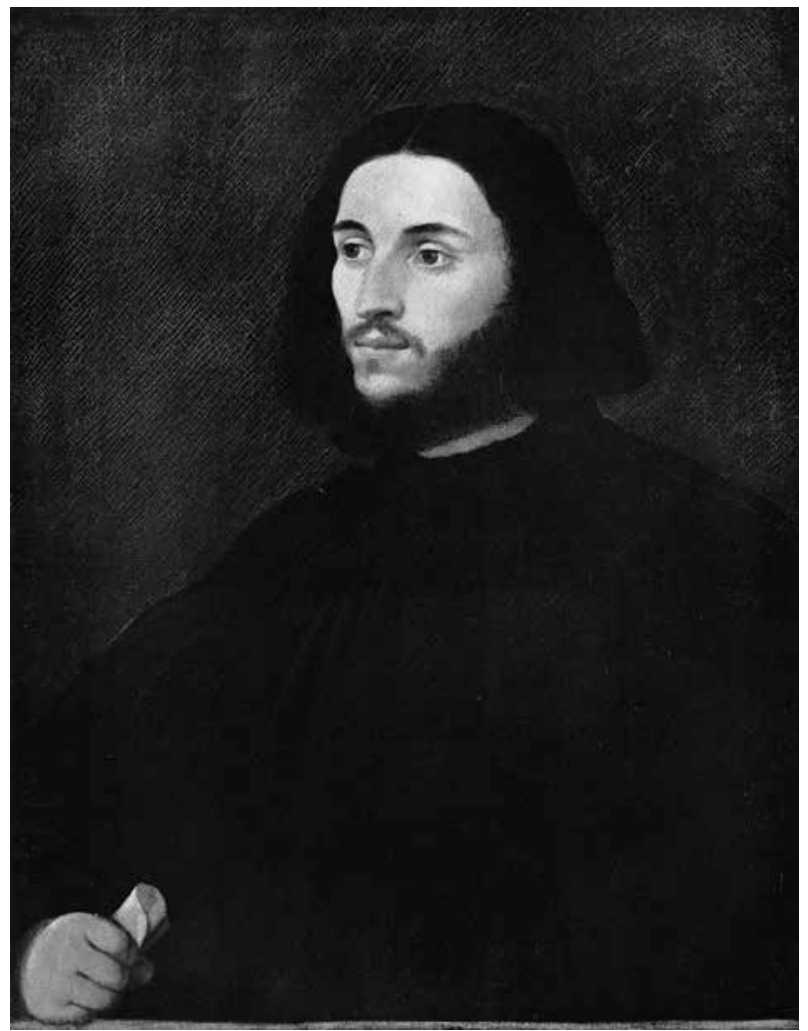

Fig. 6. Portrait of a Man; canvas, $69 \times 52 \mathrm{~cm}$; Pasadena, Norton Simon Museum

versies and discussions concerning authorship. One of the most spectacular examples of the difficulties concerned with Giorgione's paintings is the case of the so called Allendale Nativity (Fig. 10). Duveen bought the picture from Viscount Allendale for 100,000 pounds, the highest price paid for a Giorgione until that moment. Ever since it belonged to Emperor Napoleon's uncle, Cardinal Fesch in Rome (before 1841), it was quoted as a work by Giorgione, and Duveen was convinced that it was indeed an authentic painting by the master. Unfortunately, the chief authority on Italian art, Bernard Berenson - on many instances a partner of Joseph Duveen - thought otherwise. He judged it first (1895) to be by Vincenzo Catena and attributed it later to the young Titian. He could not be moved to change his mind, asserting that it was Giorgionesque, but not by Giorgione's own hand. When the Nativity was offered for sale by Sir Joseph to one of his most important clients, Andrew Mellon, this opinion proved to be fatal. The main authority's confirmation missing, Mellon called the deal off, stating firmly that "I don't want another Titian, find me a Giorgione". ${ }^{19}$ It was only some time later that Duveen succeeded in selling it to another art collector, Samuel H. Kress (1938). It is an exceptionally beauti- 
ful and important work of art, which hangs now with the Kress Foundation in the National Gallery of Art in Washington, but the discussion still goes on whether it is by Giorgione or by Titian. Though particularly successful with his collecting, Andrew Mellon's other efforts to acquire a work by Giorgione equally failed. When the Secretary of State entered the transaction to buy paintings from the Hermitage in St. Petersburg, Giorgione's early masterpiece, Judith (Fig. 7) was on the list of pictures intended for the projected National

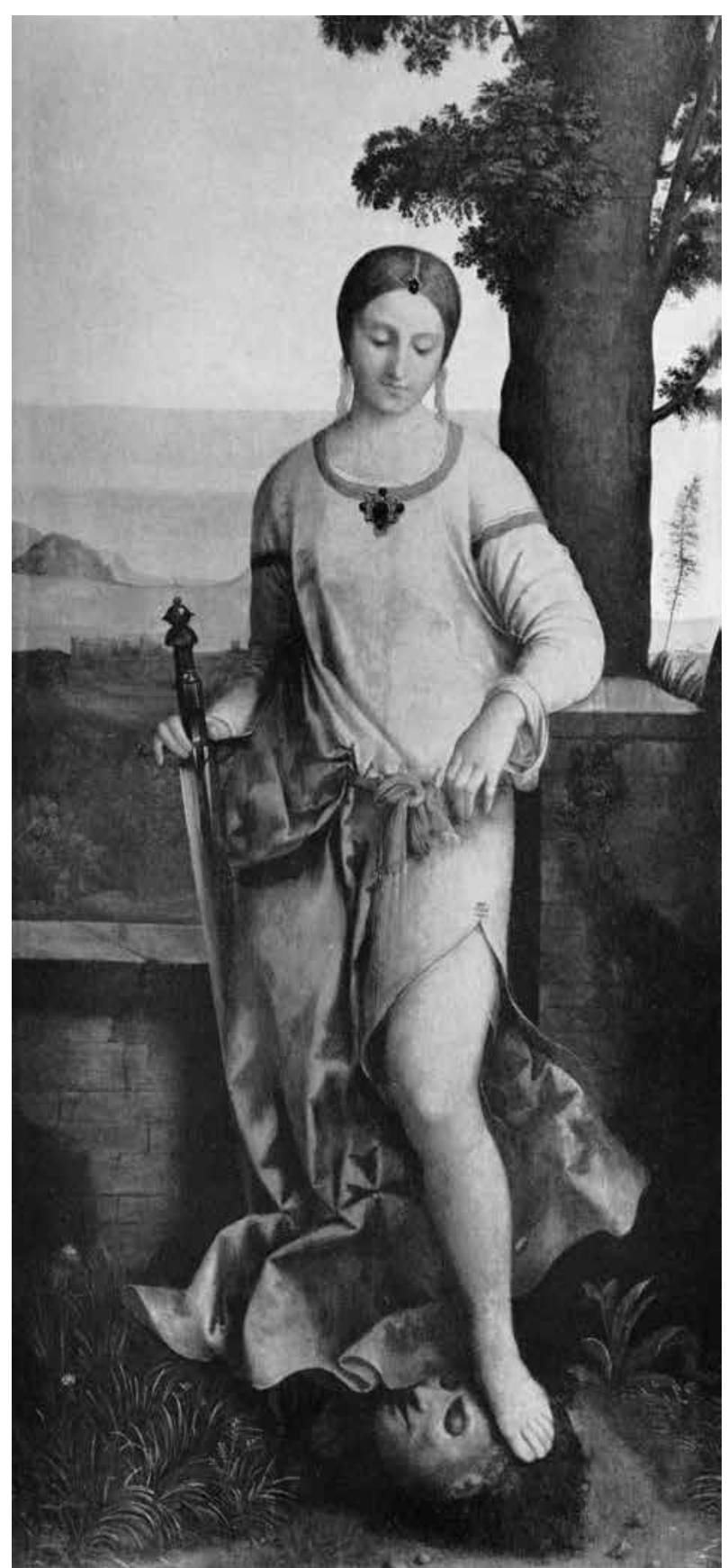

Fig. 7. Judith; canvas on panel, $144 \times 66.5 \mathrm{~cm}$; St. Petersburg, Hermitage
Gallery in Washington. But because of an extremely high price, 170,000 pounds (?) claimed for it, this part of the otherwise successful deal did not come about, and the Judith is, as ever since the eighteenth century in the Hermitage. ${ }^{20}$

A more effective and substantial chapter in the history of Giorgione in America is connected with the outstanding collecting activity of the millionaire Samuel H. Kress (1863-1955). Among the many hundred Italian paintings he had acquired on the international art market, partly through the Duveen brothers, but mostly through Count Contini Bonacossi in Florence, there are several that are considered by critics as authentic works of Giorgione. There are a number of others that have been ascribed to the master in the past, but the possibility that they belong to his closest circle instead is still subject to consideration in the literature on Giorgione. ${ }^{21}$

Doubts and controversial opinions as well as extremely high expectancy in prices made it indeed very difficult to enrich American galleries and collections with works of that very rare master of Italian Renaissance. In some cases it was a strong personal commitment and consequent research that proved to be helpful in getting results. This was the case with the author and collector Duncan Phillips (1886-1966) for instance, who, besides acquiring a painting considered to be by Giorgione, wrote an essay and then an important book on the master: The Leadership of Giorgione (1931). It is the only monograph written by an American critic on Giorgione. His journeys abroad, his close contact with the distinguished art historians of the period all document an intense interest in solid research and a fine connoisseurship. ${ }^{22}$ His correspondence with B. Berenson shows his active involvement in research related to Giorgione. He asserted quite often his own conception, even opposing Berenson, as for instance with regard to the Allendale Nativity, which he considered to be by Giorgione. The Giorgionesque painting he bought in 1939, the so called Astrologer (Fig. 16), now in the Phillips Memorial Gallery in Washington belongs to the group of "furniture paintings" closely connected with Giorgione. It is accepted by a number of critics as having been created by the master or coming at least from his immediate entourage.

A comprehensive survey of works by or attributed to Giorgione in America was presented at the exhibition Giorgione and His Circle in 1942 at the Johns Hopkins University, Baltimore. ${ }^{23}$ Though there had been several exhibitions showing Venetian paintings, this was the only one until today that was entirely dedi- 
cated to the master, presenting seventeen items as by Giorgione and a number of works by his followers, Giovanni Cariani, Sebastiano del Piombo and other North-Italian painters of the period. The catalogue with the contribution of G. M. Richter and edited by George de Batz gives an accurate account of the paintings and drawings that came mainly from private collections. Among the pictures exhibited as by Giorgione we might mention the so-called Benson Madonna (now in the National Gallery, Washington, Fig. 12), the Astrologer from the Phillips Memorial Gallery, Washington (Fig. 16), the Circumcision from the Yale University Gallery, New Haven, the Mars and Venus (Figs 2, 8) in the Brooklyn Museum, New York. There was also the Paris (?) exposed from the collection of Frank Jewett Mather, Princeton, the Female Bust from Lord Melchett's (now in the Norton Simon Museum, Pasadena; Fig. 28), the Pastorello (Page Boy with Fruit) from the Strode Jackson collection, later with Knoedler in New York, the Man of Sorrows from the Bourbon property, sold recently at Sotheby's in London (December 1993) as Palma Vecchio. One could see the Portrait of a Man from the Bache collection (now Norton Simon Museum), a Boy with a Flute from Captain Johnston's possession (ascribed lately to Palma Vecchio), the much discussed Appeal in the Institute of Arts in Detroit, with the three half-figures as presumed by three different masters, but now accepted as a work by Sebastiano del Piombo. In fact almost all the paintings presented at the Baltimore exhibition are dealt with in the literature on Giorgione and included in recent monographs (P. Zampetti, T. Pignatti, etc.), variously interpreted as works by or attributed to Giorgione, as eventual imitations or copies. ${ }^{24}$ Since this event and in the last decades works connected with Giorgione have turned up in America only on exceptional occasions. Among these we have to mention the Bust of a Boy, also called a Page Boy (Fig. 9) from Knoedler's in New York that figured at the Giorgione exhibition in Baltimore in 1942 and the Venetian exhibition in Los Angeles in 1979 as a work by the master. ${ }^{25}$ It was accepted by several scholars, among them T. Pignatti, G. M. Richter, L. Berenbaum, etc. and connected by some (K. F. Suter) with the Pastorello che tien in man un frutto by Giorgione mentioned in 1531 by Marcanton Michiel to be in the house of Zuan Ram in Venice. Though this identification was often contested and the subject interpreted as a page boy or the young Paris with the golden apple, the close relation with Giorgione could not be denied. There exist several versions of the composition, one in the Galleria Ambrosiana in

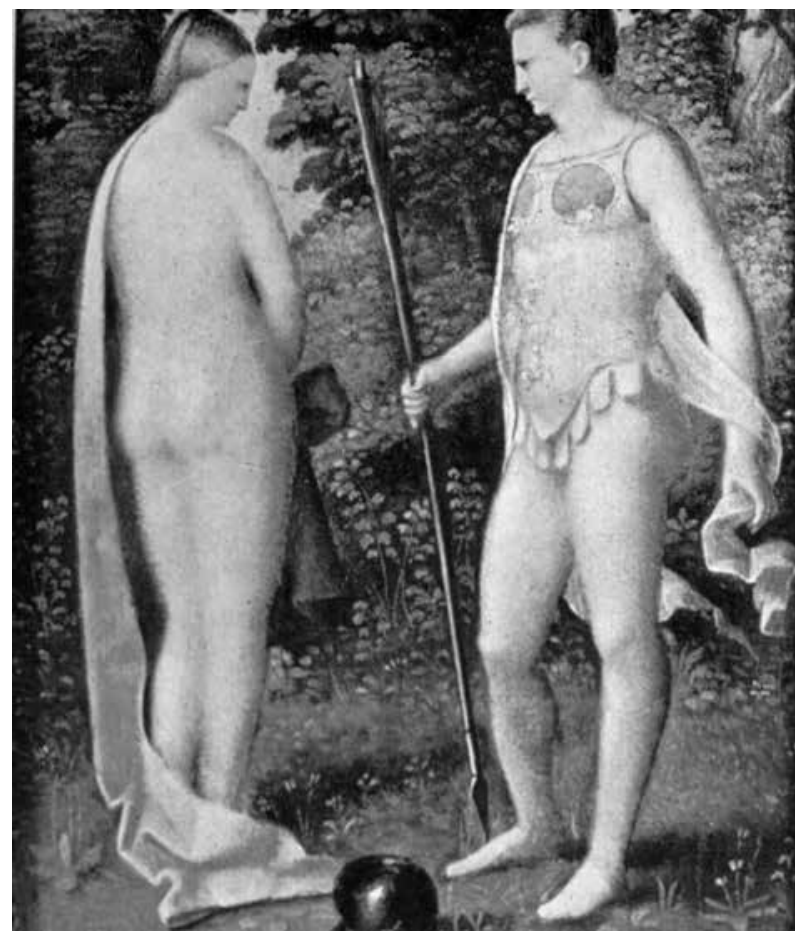

Fig. 8. Venus and Mars; panel, $20 \times 16 \mathrm{~cm}$; New York, Brooklyn Museum

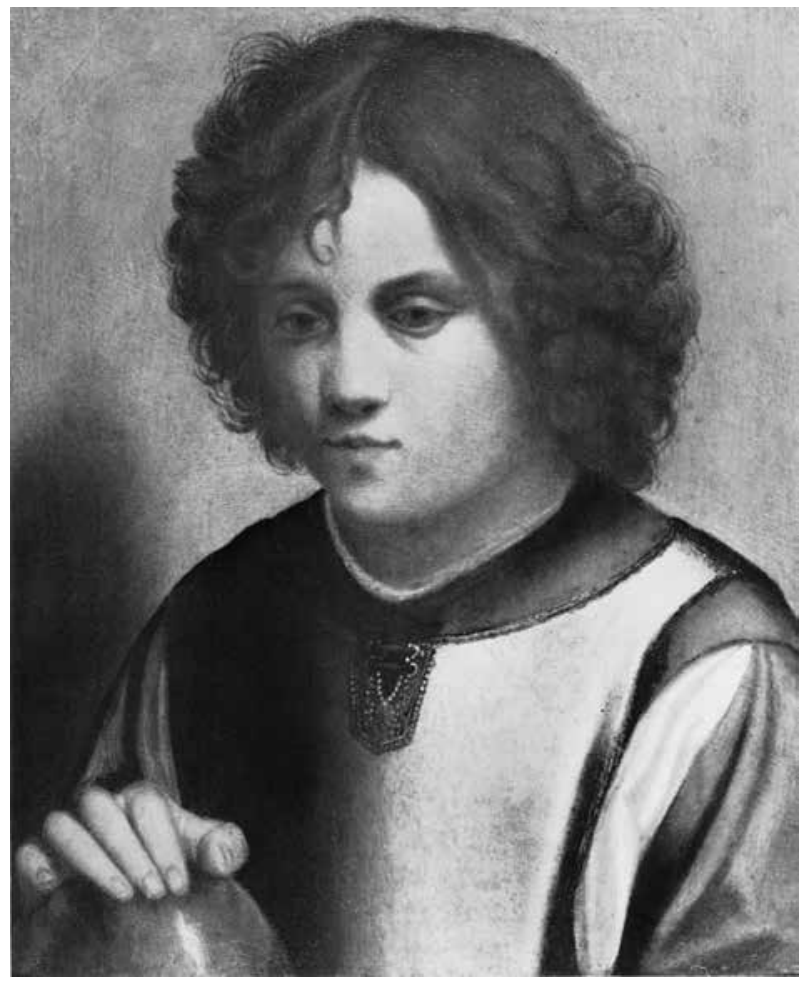

Fig. 9. Portrait of a Boy; panel, $24.5 \times 20.8 \mathrm{~cm}$; New York, Knoedler Collection

Milan, previously named Young Saviour when in the collection of Cardinal Federigo Borromeo probably by Andrea del Sarto. 26 
Another painting thought to be related to a picture quoted in the early sources as a work by Giorgione entered, in 1982, the collection of Barbara Piasecka Johnson in Princeton. The Dead Christ Held by an Angel (?) was first taken notice of in 1953 when in private collection in Venice, whence it went to New York in 1959. Published by R. Pallucchini (1959-1960) it was identified with the Dead Christ on the Tomb with the Angel Holding Him described by Marcanton Michiel in 1530 in the house of Gabriele Vendramin, Venice with the remark, "fo?? d?e man de Zorzi da Castelfranco reconzata da Tiziano", that is, by the hand of Giorgione finished by Titian. It is thus that the Pietà is valued by most of the scholars, i.e. by H. Tietze, L. Coletti, P. Zampetti, T. Pignatti as a late work by Giorgione (the angel) and Titian (Christ). ${ }^{27}$ Others seem to doubt this attribution (H. Wethey, J. Anderson, Ch. Horning) and there are also problems regarding the eventual identification with the Giorgione painting once with Gabriele Vendramin. The list of works offered for sale to Cardinal Leopoldo Medici in 1674 by Cavalier Fontana, owned earlier by the painter Nicolo Renieri and coming partly from the Vendramin collection quotes the Dead Christ with an Angel by Giorgione with whole-length figures in a horizontal composition. ${ }^{28}$

The same collection, the "camerino delle anticaglie" of Gabriele Vendramin in sixteenth-century Venice and similar questions of provenance emerge as dominant factors in the history of another Giorgione composition that has turned up recently in the USA, the so called Three Ages of Man or Marcus Aurelius with Philosophers (Fig. 20). As it is going to be dealt with in detail in this essay in connection with the above mentioned picture, it might be sufficient to mention here that, until the 1960s, only the version in the Pitti in Florence had been known and dealt with, which was interpreted and attributed in rather controversial ways in art literature. Recent restorations, technical and chemical analysis, as well as thorough historical investigations have led to important new results and interesting deductions concerning this work. ${ }^{29}$

As revealed by all these examples, the history of collecting Giorgione in America is closely connected with the fate and development of collections of past centuries in Italy and elsewhere in Europe. Thus we have to face a number of general problems and open questions regarding Giorgione's work and activity. We must try to find answers for instance to problems related to subject and conception, to the destination of different types of pictures, as well as to the role of patrons, collectors and commissions. There are also important questions of replicas, versions, variants as practiced in sixteenth-century Venetian workshops and the circle of Giorgione. We have to take into account the possible participation of pupils and eventual collaborators in his production. Though we are dealing here only with a dozen paintings, the field of investigation is rather large, this survey can only attempt to draw the outlines, to summarize the known data and to offer additional propositions with regard to some of the problems.

"Every critique has his own private Giorgione" wrote about a hundred years ago the great expert of Italian art, B. Berenson. It was on the occasion of an exhibition in London in 1895 that he expressed this opinion, rejecting most of the attributions of pictures presented as by Giorgione in the New Gallery. It was about that time that an American author, Frans Preston Stearns pointed out that "there has been more discussion concerning the authenticity of Giorgione's pictures than any other master". ${ }^{30}$ The scarcity of contemporary documents, the relatively short period of his activity, even his special field - the fresco, a fragile and perishable technique -, all caused uncertainty in the knowledge of his art. The concept of who he was and what he did changed from century to century, became confused, had to be reconstructed painfully and has not reached a consensus of opinions until this day. It is a well-known fact that there are only very few - not more than a handful of - works which are authenticated by documents, contemporary testimonies or inscriptions considered indisputably his. It is also a fact that most of the pictures ascribed to him are discussed and contested by one or the other of the experts, and that opinions change and vary all the time in almost all the questions, concerning authorship, chronology and subject. Our ideas regarding his career and his work comprises a mass of assumptions, traditions as well as errors and misunderstandings.

Uncertainty and doubt began almost at once when the painter died in Venice in 1510 at the age of about 34 , leaving behind a few frescoes - which soon disappeared - and panel paintings mostly in private possession, and only very few in public places. Already when the art loving patrician, Marcanton Michiel visited the Venetian palaces and collections making notes of their contents, questions arose about some of the alleged Giorgione paintings. So he mentions the Boy with an Arrow in the house of Antonio Pasqualino (1532) as one of which another collector, Zuanne Ram owns a copy, believing it to be the original. At Antonio Pasqualino's he also saw a head of S. Jacomo (Giacomo) 
by Giorgione or by one of his disciples, made after the S. Rocco Christ. Michiel also mentions a few paintings by Giorgione - the Venus in Casa Marcello, the Dead Christ with Gabriele Vendramin, the Three Philosophers at the house of Taddeo Contarini-, as having been finished by pupils of the master, Sebastiano del Piombo or Titian. ${ }^{31}$ In the first edition of his Vite published in 1550, Vasari speaks of the famous Christ Carrying the Cross in the Scuola di S. Rocco as of a masterpiece by Giorgione, in the second edition (1568) he quotes it as a work by Titian, adding that it was erroneously considered by some to be by the elder master. ${ }^{32}$

Reports of works by Giorgione from the sixteenth or early seventeenth century are very scarce and their credibility has to be weighed very carefully. The closer the eventual descriptions, biographies and inventories are in place and time to Giorgione's activities, the more faith can be put into them, though we also have to distinguish between data based on first hand tradition, between offers for sale or legal documents compiled by experts. Most valuable information can be found in some documents which have lately come to light like the inventories of the famous Venetian collection of Bartolomeo della Nave and the reports of its acquisition by the British ambassador, Basil Fielding (1636-1637). ${ }^{33}$ In these detailed accounts we find important notes on works by Giorgione or masters close to him, with hints to differing opinions, even an attempt to chronology soundly based on expert local information.

Almost all Giorgione paintings quoted in these sixteenth- and early seventeenth-century documents can be traced with great probability. Of those we know, some are accepted or acceptable as being authentic. Among the rest, there are several from the closer circle of Giorgione, eventually considered as by Sebastiano del Piombo, Palma Vecchio, Giovanni Cariani or Dosso Dossi and Titian. ${ }^{34}$ From the middle of the seventeenth century, when we have to deal with much more documents, local descriptions, inventories and biographies, when art market and art export are in bloom, the situation gets somewhat out of control. Our ideas and image of Giorgione undergo a change and deformation. This leads to a mixture of rather heterogeneous material appearing in the life of Giorgione by Carlo Ridolfi in his Maraviglie dell'arte published in Venice in 1648. Valid data, sound tradition, hearsay information, gossip and misunderstanding are mingled in the book in a confusing way. Paintings of poetic, pictures of romantic character, wherever encountered, usually come to be included in the oeuvre of the master, so the distinction between Giorgione and the painters that are in any way close to him is fading. Sometimes there are really Giorgionesque works that come into his orbit, but very often we encounter paintings mentioned, that for us seem to be totally alien to the original practice of sixteenth-century painting and to Giorgione. Worse than that, there are painters and dealers in the seventeenth century, who, following up on these misconceived ideas, go on to fabricate items that are put into circulation as works by the master. These imitations, copies and falsifications considerably disturb and complicate the later notion of Giorgione. We have to mention in this respect in the first place the Venetian painter Pietro della Vecchia (Muttoni) who was well known in his time to have counterfeited with intent the master's oeuvre. His clever imitations are easily recognizable for us with their distinctly seventeenth century character, but they were well apt to misguide collectors and critics, as is documented in the case of the false Giorgione Self Portrait offered for sale to Cardinal Leopoldo de Medici. ${ }^{35}$

The further we get from Giorgione's time and space, the vaguer and more fictitious our notion of his art and life gets. Few ideas concerning romantic subject, bizarre costumes, dramatic action with colourful figures seem to determine many attributions of Giorgione in the eighteenth and nineteenth centuries. Hardly any distinction was made between originals, replicas, works of followers, imitations or late copies or even paintings which were entirely alien to Venetian art and Giorgione. It is only with the establishment of scholarly art history, with thorough stylistic comparison and use of documents that a more faithful aspect could be realised and a solid stock of works recognized since the end of the nineteenth century. But it was only in the last decades, that the large field of Venetian painters of the fifteenth and sixteenth centuries came to be revealed, that the product of minor masters from Giorgione's entourage could be distinguished and differentiated. Ample documentation, technical investigation as well as a detailed iconographical examination made it possible to outline more exactly the development of Giorgione's art, and the character and chronology of his work. Concerning many questions there is still no agreement between the different scholars. Only very few of Giorgione's paintings are recognised and accepted by all of the critics, so the number of documented, authentic works is very limited.

In this essay, which deals with the pictures known as by Giorgione in the USA, there is certainly no reason to discuss all the problems related to Giorgione, 
or to present his career, his role and importance in Italian Renaissance painting, or to review his style and oeuvre. That has been done extensively by experts in several large monographs and innumerable articles, papers, and catalogues. Trying to outline the presence of Giorgione and his work in America, I must content myself with summing up the results concerning the paintings shown in public and accessible in different museums and galleries all over the United States. ${ }^{36}$ Presenting the main data, the known facts and the different opinions or interpretations, it is not possible here to decide upon the disputed questions, it would be unrealistic trying to establish final solutions. Only some suggestions, data that hitherto escaped notice can be added to the different items.

Though we are only dealing here with a dozen paintings, a mere fragment of Giorgione's oeuvre, we could not evade to face a number of general problems, among others the question of workshop practice at the beginning of the sixteenth century, the participation of pupil collaborators, the question of replicas, variants and imitations. ${ }^{37}$ We had to look for answers to problems of subject, of destination and original location, involving the role of patrons, commissions and collectors.

\section{The Adoration of the Shepherds [Nativity] (Fig. 10)}

Wood, $91 \times 111 \mathrm{~cm}$

Washington, National Gallery of Art, No. 1939.1.289

Provenance: Collection Cardinal Joseph Fesch, Paris, from M. Montigneul before 1799, Cardinal Joseph Fesch sale, Rome, 1841 Nr. 644, 1845 Nr. 874 as "Admirable production de Giorgione"; bought by Claude Tarral, Claude Tarral Sale, London, Christie's, $1847 \mathrm{Nr}$. 55; sold to Thomas Wentworth Beaumont, Bretton Hall, inherited by Wentworth Blackett Beaumont, First Lord Allendale, then First and Second Viscount Allendale, London, always as Giorgione; bought by Joseph Duveen, New York, 1937; sold to Samuel H. Kress, Washington, 1938.

Exhibited: London, British Institution, 1848, No. 20, 1862, No. 121; London, Royal Academy, 1876, No. 201, 1892, No. 112, 1930, No. 395; London, Burlington Fine Arts Club, 1912, No. $58^{38}$

Concerning the earlier provenance it has been suggested that it might be the "quadro de un prexepio de man de Zorzi da Castel Franco" valued ten ducats in
1563 in Venice, in possession of Giovanni di Antonio Grimani. It had also been tentatively identified with the Nativity ascribed to Giorgione in the collection of King James II of England (cat. 1688, Bathoe 1758 No. 192 - earlier King Charles I and Gonzaga collection, Mantua), but this proved to be in fact the Adoration in the Royal Collection, Hampton Court (inv. no. 135), an altogether different composition. ${ }^{39}$

Several of the Nativity or Adoration scenes attributed to Giorgione in old inventories and descriptions might also be taken into consideration. The connoisseur and art dealer Paolo del Sera mentions in 1642 a beautiful painting on panel by Giorgione representing the Nativity of Christ with the Shepherds in the hands of a certain Pietro in Venice. This is perhaps the same he speaks of later in 1667 as of an early work by Titian, a beautiful Nativity, presented by him in 1668 to Pope Clemens IX. Rospigliosi. ${ }^{40}$

A Nativity ascribed to Giorgione was seen in possession of the Earl of Northumberland in 1658 in Suffolk House by John Evelyn. An Adoration of the Shepherds by Giorgione was quoted in 1727 in the collection of the Duc d'Orléans in the Palais Royal, Paris - this is the early Sebastiano del Piombo now in the Fitzwilliam Museum, Cambridge. A Giorgione's Adoration of the Shepherds figured in 1732 in the famous Châtaigneraie collection in Paris (cca. $100 \times 130 \mathrm{~cm}$ ), another one at the Duc de Tallard Sale, Paris, 1756, as coming from the collections of Comte de Morville and de Nocé (cca. $64.8 \times 91.8 \mathrm{~cm}$ ). As the Allendale picture was bought by Cardinal Fesch in France before 1799 , it could be eventually identical with this last one based on the measurements. ${ }^{41}$

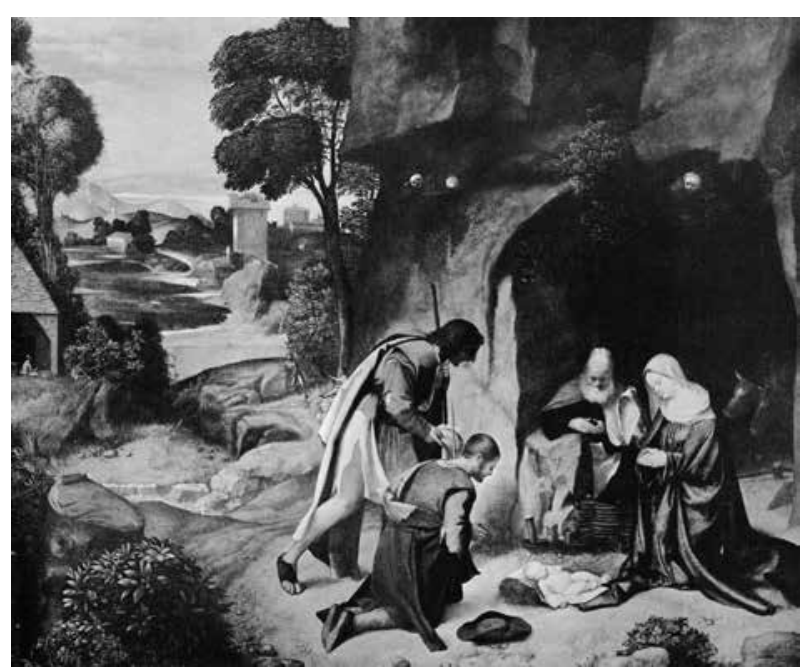

Fig. 10. The Adoration of the Shepherds (Nativity); panel, $90.8 \times 110.5 \mathrm{~cm}$; Washington, National Gallery of Art 
The essential question concerning the origin of the Adoration is the much discussed problem whether it can be identified with one of the Noctes mentioned in 1510 in the correspondence of Isabella d'Este. At the time of Giorgione's death in October 1510, the Marchioness of Mantua inquired after a picture of the Nocte, which was reported as being "molto bella e singolare" in the studio of the master, and which she wished to acquire. Her agent, the Venetian nobleman Taddeo Albano answered the $7^{\text {th }}$ of November from Venice that there was no picture of that description left in the estate of the master; though it was true that Giorgione did paint certain Noctes. One for Taddeo Contarini, which is not "molto perfecta", and another one owned by Vittorio Becharo "de meglior desegnio et meglio finitta". As Albano stated, none of them were for sale for no price at all, because they had them made for their own enjoyment. ${ }^{42}$

Several authors (H. Cook, A. Morassi, G. Fiocco, G. Heinz) connected this reference of the Nocte with two existing versions of the Adoration, the Allendale painting in Washington, and the other one in the Vienna Museum. This suggestion has been rejected by H. Tietze - E. Tietze-Conrat, Sh. Tsuji, F. Gibbons, E. Waterhouse. The interpretation of the Nocte as a Nativity was questioned as not being in accordance with sixteenth- and seventeenth-century practice. The history and investigation of the Vienna version might help us to solve this problem. ${ }^{43}$

\section{The Adoration of the Shepherds [Nativity] (Fig. 11)}

Wood, $91 \times 115 \mathrm{~cm}$

Vienna, Kunsthistorisches Museum, Inv. No. 1835

Exhibited: Venice, Giorgione, 1955, Nr. 9

The Vienna version of the Adoration was part of the collection of Archduke Leopold William in Brussels-Vienna, inherited by Emperor Leopold I. In the inventory of the Archduke, in Vienna, 1659 (Inv. No. 217), it is quoted as a "night piece with the Nativity of Christ in a landscape, the child lying on the earth, with Joseph and two shepherds and two angels in the height". "It is thought to be an original by Giorgione." (Wood, $5.4 \times 6.4$ span cca.)

It came to the Archduke with the collection of the Marquess of Hamilton bought from England in 1649, figuring in several Hamilton inventories as "Giorgione La Naissance de nostre Seigneur". It was bought for

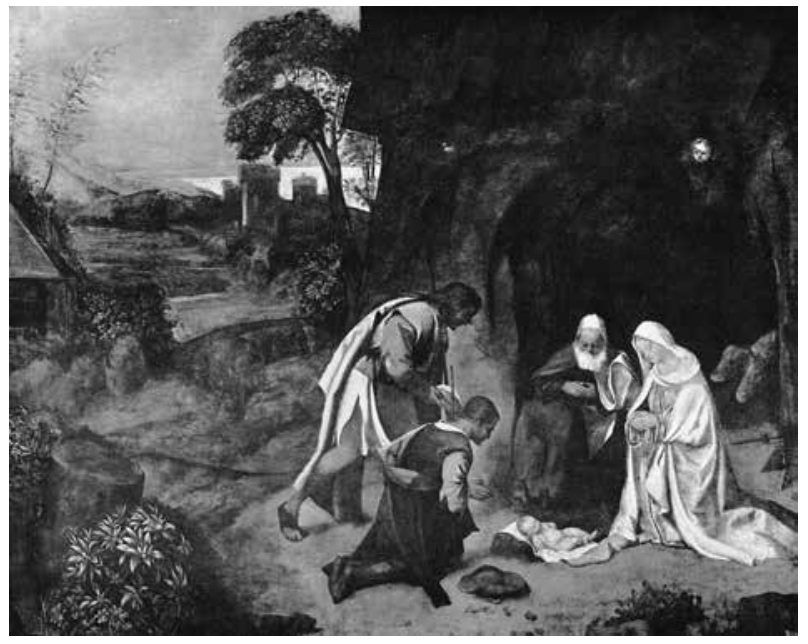

Fig. 11. The Adoration of the Shepherds (Nativity); panel, $91 \times 115$ cm; Vienna, Kunsthistorisches Museum

Hamilton by his brother-in-law, Basil Fielding, British ambassador in Venice (1636-1637) with the famous collection of Bartolomeo della Nave: quoted in the inventory of 1636 No. 45 as "Giorgione Our Lady and the Nativity of Christ and Visitation of the Shepherds". ${ }^{44}$ Della Nave owned also the Three Philosophers and the Finding of Paris by Giorgione, the paintings that were described in 1525 by Marcanton Michiel in the house of Taddeo Contarini, ${ }^{45}$ the same Venetian nobleman, who, according to the letter quoted above by Taddeo Albano in 1510 owned the Nocte by Giorgione, one of the two versions which was not quite finished. The fact, that several of the Leopold WilliamDella Nave paintings were originally in possession of Taddeo Contarini, and also the circumstance that it is indicated in 1659 as a night piece are strong arguments in favour of its identification with the Nocte mentioned by Taddeo Albano in 1510 as Taddeo Contarini's. The other version in Washington must be Victorio Becharo's painting of the same subject which was "of better design and better finished". In fact, the two pictures in Washington and Vienna are almost identical in composition and setting, there are slight differences only in the landscape and accessory details. It is hard to imagine that all these indications and connections should be incidental and that there had been another pair of paintings answering all the given data and documents.

The probable identification of the two Adoration of the Shepherds with the documented Nocte painting in Venice in 1510 is also of special interest for the problem of authorship as well as in connection with the question of second versions or replicas in the practice of Venetian painters in the early sixteenth century. We know that variously documented compositions 
often existed in more than one version, produced by the master himself or by his workshop, eventually at the request of different customers, or to replace some work already alienated. In his Venetian reports, Marcanton Michiel mentions for instance a few examples where he encountered works attributed to Giorgione in more than one version. There was the Boy with an Arrow in the house of Antonio Pasqualino and with Zuanne Ram (1531-1532), both held to be originals by the owners. He also speaks of a head of St. James, after the Christ in S. Rocco, thought to be by Giorgione or else by a pupil of him. ${ }^{46}$

Beside the two existing and probably autograph versions of the Adoration of the Shepherds there are some of the closely connected works to be taken into consideration. In the Royal Collection, Windsor (No. 12803) there is a drawing that shows the composition with the central figures, Mary, Joseph and one of the shepherds in a similar position, with the same gestures before a slightly changed background and in a different position on the ground. By the judgement of most critics, this might be a sketch of the Allendale Nativity, according to the opinion of other scholars it must be a copy of it.

A fragmentary copy of the Allendale Adoration - the left part and the top missing - was in the collection of Frederick Cook, Richmond (1913) previously in the possession of Wentworth Beaumont that is like the original with Lord Allendale. Part of the composition - the child and the kneeling shepherd - was also imitated in the Adoration by Francesco Vecellio, once the altarpiece in S. Giuseppe in Belluno, consecrated in 1507 (now Houston, Museum of Fine Arts from F. Cook's collection). ${ }^{47}$

All the historical and stylistic elements encountered in the Adoration of the Shepherds here discussed indicate a dating of the picture at about 1505. This is accepted by most of the critics, though concerning authorship there has been and still is controversy and discussion. Traditionally ascribed to Giorgione - since the Fesch catalogues of 1841 - this attribution accepted by Crowe and Cavalcaselle (1871) was questioned by B. Berenson, who first suggested the name of Vincenzo Catena, thought it later to be a Titian or Giorgione with Titian finishing it (1957). His doubts concerning the authorship of Giorgione led to a serious controversy with Joseph Duveen and to complications in selling the painting in the USA. The various suggestions of painters like Catena, Cariani, Giovanni Bellini, etc. by G. Gronau, Lionello Venturi, G. M. Richter, Roger Fry, A. Venturi, Hans Tietze and Erica Tietze-Conrat, etc. all have in common the doubt in the authorship of Giorgione in some cases admitting he might have had a part in its execution together with some other painters. B. Berenson, S. J. Freedberg, Magugliani, etc. are in favour of an attribution to the young Titian. The majority of scholars, especially in these last years, tend to accept it as an autograph work by Giorgione, the Vienna version being mostly a copy of it. We can mention in this connection: H. Cook (1900), R. Longhi (1927, 1946), W. Suida (1935, 1956), L. Justi (1936), A. Morassi and P. Zampetti (1955), L. Coletti (1955), R. Pallucchini (1963), T. Pignatti (1969). ${ }^{48}$ Lately the arguments in favour of Giorgione seem to gain upper hand. The thorough investigation of painters like Vincenzo Catena, Giovanni Cariani, Girolamo Savoldo, etc. led to the elimination of several of the earlier tentative suggestions. The attribution to the young Titian could not be supported by facts and remained a suggestion entangled with the problem of Titian's early development and his connection with Giorgione's art.

Open to speculation remains also the question of the eventual relation of the Washington composition to the hypothetic and doubtful Nativity known to have been painted around 1504 for Isabella d'Este. As there exists no description of it - it is not cited in the Mantua inventories -, the assumption of scholars that it was conceived like the Allendale Adoration or the drawing in the Windsor Castle remains hypothetic and doubtful. Tietze's suggestion, that it might be identified with the lost Bellini painting is generally rejected and only the conception remained that it could have been painted in Bellini's studio by the young Giorgione or the young Titian. New findings, like the strongly Bellinesque underdrawing similar to the Madonna in Adoration and found on the recently restored Three Ages of Man painting in Florence (see Fig. 21) certainly give support to the notion of Bellini's inspiration in paintings of the Allendale group (The Holy Family, Washington, see Fig. 12, The Adoration of the Magi, London, National Gallery, etc.). ${ }^{49}$

\section{The Holy Family (Fig. 12)}

Transferred from wood to masonite, $37.3 \times 45.6 \mathrm{~cm}$ Washington, National Gallery of Art, Nr. 1091

Provenance: From French private collection, sold in Brighton, England in 1887 to Henry Willett; 1894 Collection Robert H. and Evelyn Benson, London, as Giorgione; 1927 bought by the Duveens, New York; 1949 sold to Samuel H. Kress. 
Exhibited: London, New Gallery, 1894-1895, No. 148; London, Burlington Fine Arts Club, 1909-1910, Nr. 43, 1912, Nr. 17; London, Grafton Galleries, 1909-1910, Nr. 81; New York, World's Fair, 1939, Nr. 144; Detroit Institute of Arts, 1941, No. 21; New York, Knoedler Galleries, 1948, Nr. 8; Baltimore, Johns Hopkins University, 1942, Nr. 2; Paris, Louvre, 1993, No. 15.50

It has been suggested that it might be The Virgin and Child and St. Joseph from the Mantuan collection quoted as by Giorgione in the inventory of King James II, probably coming from the collection of King Charles I of England. In fact it cannot be traced in any of the inventories of Charles II (1639, 1649-1650), nor in the Mantuan inventory of the Gonzaga from 1627. It was also connected with another ascribed to Giorgione: "Maria Joseph an het kindetje van Gyor Gyone da Castel Franco, klein Levent['??]beste hierte Lande bekent", a painting sold in Amsterdam at the sale of Allard van Everdingen, in 1709. Not noted before, this Amsterdam painting must be the one described in almost the same terms at the sale of Reynier van der Wolf in Rotterdam, in 1776-77 as "een Landschap met Maria Joseph en meer andere kleyne Figuren in t[??]verschiet" by "Giorgon da Castel Franco". 51 The identification of these items with the Washington seems to be possible, but by no means compelling.

Another problem in connection with the Washington Madonna concerns the original destination of the painting. Its small size $(37.3 \times 45.6 \mathrm{~cm})$ and its rectangular square form led to the assumption that it might have been part of a predella, that is, of the base of an altar. This was considered to be a possibility with a few other works ascribed to Giorgione, like the Adoration of the Magi in the National Gallery, London, the Holy Family in Raleigh, etc. Though Vasari, in his Vite on Giorgione expressly mentions Madonna paintings the master had painted in his early years, ${ }^{52}$ none is known to us in an authentic way with the exception of the Castelfranco altarpiece. There is no indication that Giorgione was commissioned with any other major altar, and the smaller pictures of the Holy Virgin in private possession quoted in sixteenth-seventeenth-century inventories, like the one with Gabriele Vendramin in Venice (1567) are lost or untraced. ${ }^{53}$

If not the original destination at least the date of the little Holy Family can be stated with consensus. By most authors it is thought to be very close to the Allendale and to the Adoration of the Magi in London, and is connected with the early Giorgione. The three works

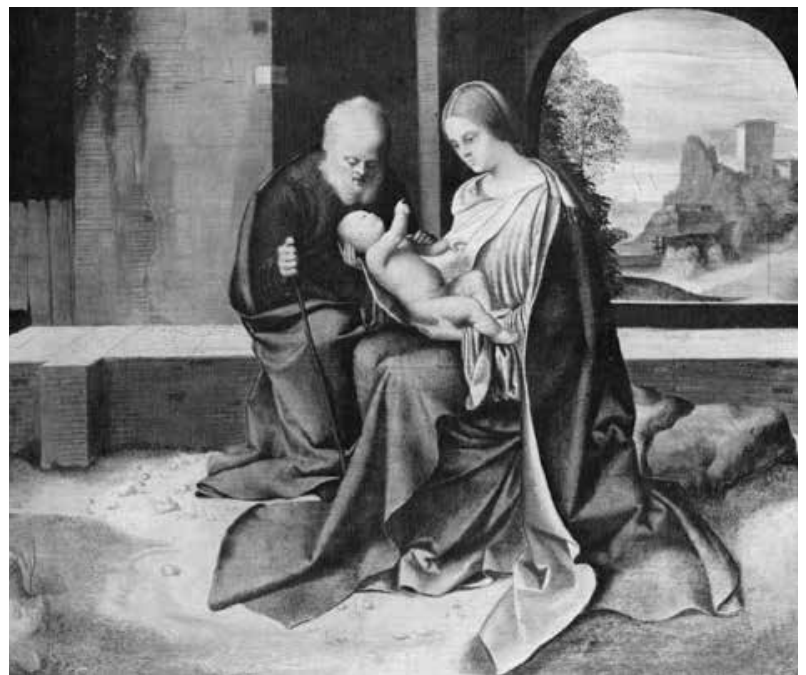

Fig. 12. The Holy Family; canvas on masonite, $37.2 \times 45.4 \mathrm{~cm}$; Washington, National Gallery of Art

show a strong similarity of features in the types of heads, draperies and gestures, hairdo and costumes, landscape details as well as in the fine texture and brushwork. There is also a drawing in Christ Church, Oxford attributed to Giorgione showing an old man sitting, very much like St. Joseph in the Holy Family or the Adoration of the Magi. Further, there is the small Adoration of the Child from the Kress Collection in the Raleigh Museum (Fig. 13) and a somewhat larger one

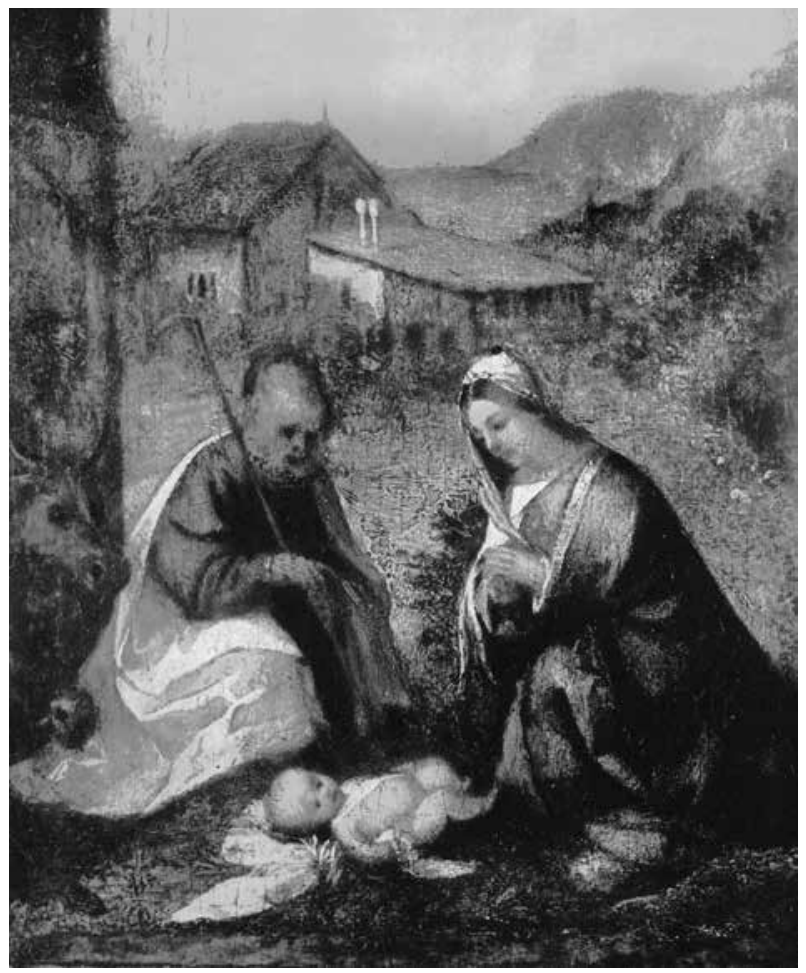

Fig. 13. The Adoration of the Child; panel, $19 \times 16.2 \mathrm{~cm}$; Raleigh, North Carolina Museum of Art 
in the Hermitage, in St. Petersburg, both compositions in some way related to the group in discussion. ${ }^{54}$ Their stylistic relation with Giovanni Bellini on the one hand, and with works by Giorgione like the Judgment of Solomon and the Trial of Moses in Florence or even the Tempesta on the other permit to date them between 1500-1504. Though there have been several alternative suggestions, voting for an authorship of Vincenzo Catena, Cavazzola, Sebastiano del Piombo or Bonifacio de Pitati, the majority of experts agree in attributing the Holy Family - and in part the group connected with it - to Giorgione. H. Cook, R. Longhi, L. Hourticq, W. Suida, G. M. Richter, G. Fiocco, A. Morassi, L. Coletti, P. Zampetti, T. Pignatti, A. Ballarin are among those who accept and support the Giorgione attribution. ${ }^{55}$

Taken everything into consideration this seems in fact to be the only attribution that fits all the elements of the given problem: neither Giovanni Bellini, nor Titian could be eligible - as sometimes suggested - for the very coherent group of works around the Allendale Nativity representing the trends of Venetian painting of around 1500-1510.

\section{Christ Carrying the Cross (Fig. 14)}

Wood, $50 \times 39 \mathrm{~cm}$

Boston, Isabella Stewart Gardner Museum

Provenance: 1898 bought through B. Berenson from Count A. Zileri dal Verme, Vicenza; O. Mündler in his Travel Diary mentions it in November 1855 in the house of Contessa Loschi dal Verme: "Half-length figure of Christ bearing the Cross, Giorgione. I take it to be genuine, an admirable picture." His opinion was shared by Sir Charles Eastlake. He tried to buy it, but it was not for sale then, the Countess intended to bequeath it to the Museum of Vicenza. ${ }^{56}$ Nothing was known of the earlier history of the painting.

Several versions and replicas are mentioned in the literature of the composition. G. M. Richter in his Giorgione book (Richter 1937) mentions twelve, Heinemann (Heinemann 1962) fifty-nine (including totally different conceptions). ${ }^{57}$

Replicas: Rovigo, Accademia dei Concordi, wood, $50 \times 39 \mathrm{~cm}$, from the Casilini Collection (1824, as by Leonardo). Ascribed to G. Bellini.

Budapest, Museum of Fine Arts, No. 4220, wood, $48 \times 28.1 \mathrm{~cm}$. From the collection of Count János Pálffy 1912 (Palace in Pozsony [Bratislava], as by Palma). Ascribed to Marco Bello, after G. Bellini.
Once Vienna, Lanckoronski collection, wood, $50 \times 28 \mathrm{~cm}$. From the collection of Mario di Maria, Venice, before 1893 , ascribed to Giorgione.

Stuttgart, Staatgalerie, Inv. Nr. 128, canvas, $78 \times 38 \mathrm{~cm}$. From the collection Barhini-Breganze, 1892(?) as by P. Bordone.

New York, Collection Rosenberg (1955[?]-1959), wood, $46 \times 36 \mathrm{~cm}$, earlier Count de Pourtalès, Paris-Hague-Berlin (1883[?]-[?]1898), supposedly before 1798 in the Salesian Church in Murano.

Once London, William Farer collection (by 1895) as by School of Giorgione.

New York, Ehrich Galleries, 1933, wood, $45 \times 38.1 \mathrm{~cm}$ as after Giorgione.

Crowe and Cavalcaselle (1871) mentioned a copy of the Vienna Christ with an art dealer in Padova. O. Mündler's Travel Diary quotes (1856) one in the Tanara collection in Verona.

Supposedly the prototype for all these versions and copies was a painting by Giovanni Bellini, according to some experts, the Christ Bearing the Cross in the Toledo Museum of Art (wood, $49.5 \times 38.7 \mathrm{~cm}$ ) from the collection of Marquis de Brissac and his heirs, in Paris (Fig. 15). The Toledo version is usually identi-

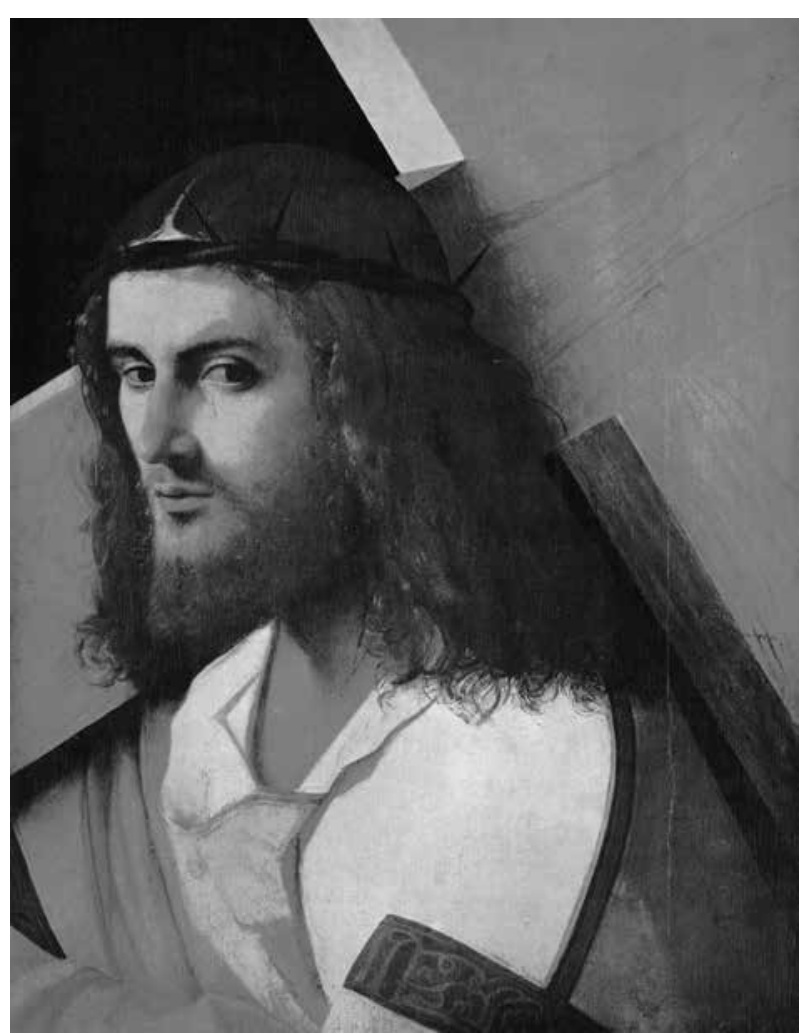

Fig. 14. Christ Carrying the Cross; panel, $59.2 \times 42.3$ cm; Boston, Isabella Stewart Museum 
fied with the half-length figure of Christ with the Cross by Giovanni Bellini, described in the house of Taddeo Contarini in 1525 in Venice. ${ }^{58}$

The relation between the different versions is rather complicated, the date, the origin as well as the problem of authors, Giovanni Bellini, and, on the other hand, Giorgione are much discussed. The conclusions can be summed up as follows: all of the paintings quoted above show the bust of Christ turned to the left, the heavy cross on his right shoulder. He is wearing a whitish garment open at the neck and decorated with a stripe or band on the sleeves. He has a short beard and long hair falling to his shoulders, with a crown of thorns on his head. There are no hands to be seen. The size is mostly about the same, with slight differences, due perhaps to ulterior cutting on the edge (Rovigo). In the Boston Christ, the type of the face, the expression is altered. Ph. Hendy in analyzing the Boston picture (1931) thought the differences to be of a chronological character, the changes in the hair and in the drapery, the direct look, the more personal, more alive expression, seem to indicate a more advanced style..$^{59}$ He feels justified to give the painting to a younger generation in the wake of Giovanni Bellini. He thought of Palma Vecchio as its master, but

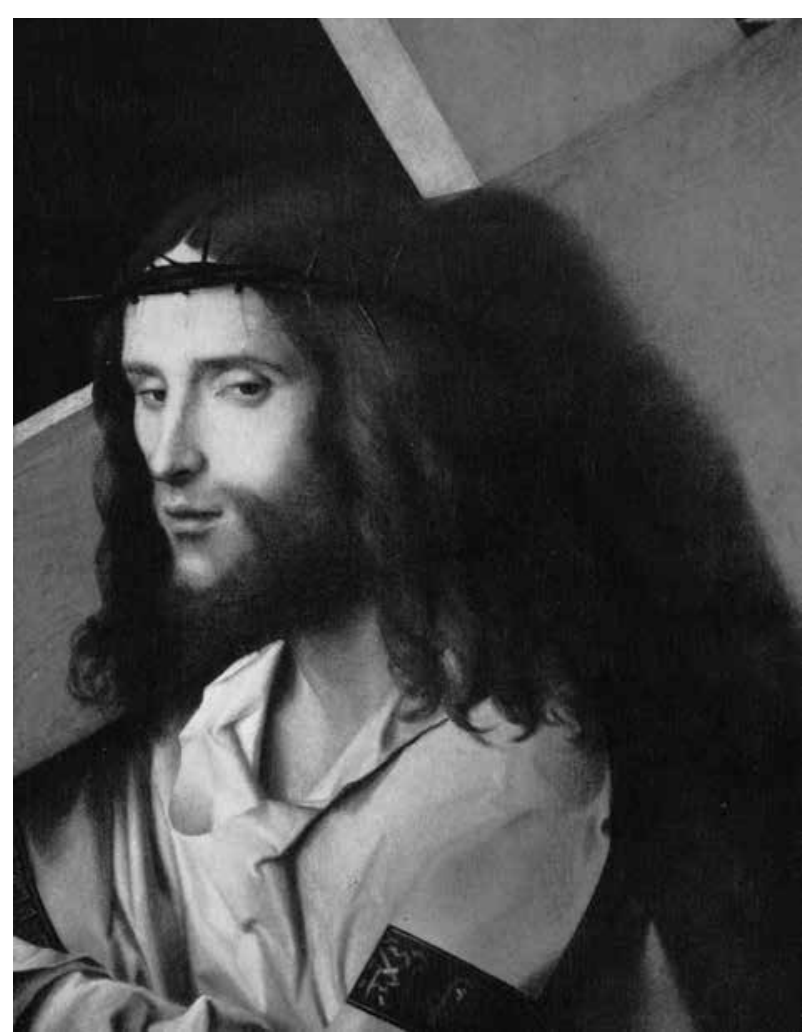

Fig. 15. Giovanni Bellini: Christ Carrying the Cross; panel, $49.5 \times 38.5 \mathrm{~cm}$; Toledo, Museum of Art ever since Morelli and Crowe and Cavalcaselle a number of authorities (H. Cook, B. Berenson, C. Gamba, L. Coletti, T. Pignatti) suggested Giorgione as author, the young Giorgione still close to his master Bellini, and copying one of his works.

Of those who question the Giorgione attribution, G. M. Richter, P. Zampetti think the Boston painting to be by Bellini or his circle. G. Fiocco, W.R. Rearick suggested D. Mancini, after an original by Bellini, others described it simply as Giorgionesque or Bellinesque. ${ }^{60}$

With all the differing opinions and arguments some of the questions concerning this composition are still unanswered. There is, to begin with, the contradiction in the fact that, as there exist so many replicas and copies, it must have been well known and accessible for a longer period. As there are later - seventeenth- and eighteenth-century versions - not all could have been copied in Bellini's studio but it could not have been kept in a private house either, i.e. in the collection of Taddeo Contarini. On the other hand, the composition is not mentioned in any of the biographies, descriptions or guidebooks. It must have been kept in a less known public place, judging by its small size probably in a chapel of a brotherhood, sculla or family, presumably in Venice or its surroundings.

Another question that needs an answer concerns the origin of the Giorgione attribution. When the Boston Christ first turns up in mid nineteenth century in Vicenza, it is known - and accepted - as a valuable work by Giorgione. There must have been a local or family tradition in this relation, going back eventually centuries. We do not know how and when it came into the possession of the Loschi family in Vicenza, and there are essentially no dates concerning the other versions' existence before the nineteenth century. We might add here just one single item unnoticed hitherto, which might help solve this problem of provenance and origin. The earliest mentioning of a Christ with the Cross on His Shoulders connected with Giorgione appears - as far as I can judge - in 1689-1691 in the inventory of the Abbot's rooms in Sta. Giustina, Padova, where it is mentioned as "cavato dal Giorgione" that is "copied after Giorgione". It does not appear in later inventories of the cloister, but in S. Croce, Padova, a church of the Somaschien, eighteenth-century descriptions (G. Rosetti, 1780; P. Brandolese, 1797) mention a little picture of the Saviour as by Giorgione or ascribed to Giorgione in the sacristy. ${ }^{61}$ This might be the picture Crowe and Cavalcaselle saw at the dealers' in Padova in the 1870s and which they thought to be a copy of the Vicenza Christ Carrying the Cross. All this seems to 
indicate that there was in fact a small composition of a single figure, a bust of Christ with the Cross attributed to Giorgione as far back as the seventeenth century. Further investigations in this direction might possibly lead to clear the problem of the original destination.

Closely related with this question and open to discussion is the iconographical interpretation, the relation of our composition to other works of the same subject, also with the famous Christ Carrying the Cross in the Scuola di S. Rocco, Venice. As demonstrated by several authors, the single half-figure of Christ with the cross was, since the 1400s a much favored subject in the North of Italy, in Lombardy, the Terra Ferma, and Veneto, etc. The fundamental type is represented in an engraving, a woodcut from the late fifteenth century showing Christ turned to the left, bearing the cross on his right shoulder, with the crown of thorns on his head, often the cord on his neck. This is how he appears in a number of paintings by Bartolomeo, Montagna, Francesco Zaganelli, Marco Palmezzano, Andrea Solario, etc. ${ }^{62}$ This type of icon, distinctly connected with medieval tradition is apparently the base of the Toledo-Boston Christ with the Cross composition, the main difference being that, with the Bellini-Giorgione versions the hands are not included in the composition, and, especially in the Boston painting, the turn of the head strengthens the contact with the onlooker. ${ }^{63}$ A peculiar feature of the composition seems to be the garment with its dark green band or stripe on the sleeve. On the Toledo version, the supposed prototype by Bellini, it bears distinctly golden Arabic letters, a Kufic inscription, there is also some kind of a script along the band leading up to the shoulder. Though this stripe exists in all the known versions, they are slightly different in each painting. On the Rovigo copy and the similar one in Budapest, the inscription and letters are indistinct; the New York version from the Pourtalès collection shows merely a Renaissance ornament. The stripe of the Boston Christ is equally of a decorative character, not a reproduction of real letters.

Originating from a common source, perhaps some miraculous icons, the future and development of the Toledo-Boston Christ can be followed up in a more definitive way. Its relation to the famous Christ Carrying the Cross in the Scuola di S. Rocco is apparent and recognized by all, but in the interpretation and the chronology there are great discrepancies. The Boston Christ and its Bellinesque variant are usually thought to be of a somewhat earlier date, closer to the middle age tradition, the religious conception of icons. The closeup of a single figure without any action is changed into a larger composition with four half-length figures in action, where Christ carrying the cross is dragged by the Pharisees. The Christ in the middle, looking out of the picture, strongly reminds one of the Christ in Boston, but is also related - as has been underlined by several authors - to a Leonardo drawing in Venice, the Bust of Christ in the Accademia di belle arti. The question of origin, date and authorship is all the more complicated and vague, as since the earliest date, there has been uncertainty concerning the painter of the S. Rocco Christ. Vasari in his first edition of the Vite spoke of it as a work by Giorgione (1550). In the second edition (1568), he quotes it as a Titian, wrongly believed by some to have been painted by Giorgione. Marcanton Michiel - by inference - seems to think it a Giorgione, while in the sixteenth- and seventeenthcentury descriptions, it appears - as also its several copies quoted in those times - variously attributed to Giorgione or else to Titian. This indecision has not ceased until this day: while the majority of critics, L. Hourticq, L. Venturi, W. Suida, A. Morassi, H. Tietze, F. Valcanover, H. Wethey among others, voted for an authorship of Titian, others like B. Berenson, G. M. Richter, L. Coletti, P. Zampetti, T. Pignatti, etc. still believe the S. Rocco Christ to be a late work by Giorgione. The relation to this important Venetian composition on one side, and its close connection with Giovanni Bellini on the other is decisive in determining the date and the origin of the Boston Christ. According to what experts suggest in this respect, its dating is vaguely put between 1500 and 1509 .

\section{Allegory of Time [The Astrologer] (Fig. 16) \\ Wood, $12 \times 18 \mathrm{~cm}$ \\ Washington, Phillips Memorial Gallery}

Provenance: Wilhelm Koller collection, Vienna, Posonyi Sale, 1872 Nr.21; Károly and Garibaldi Pulszky collection, Budapest (by 1909); Gallery St. Lucas, Vienna, 1937; Thyssen-Bornemisza collection, Lugano; acquired by D. Phillips, 1939, Washington. ${ }^{64}$

Exhibited: Baltimore, Giorgione, 1942, Nr. 1; San Francisco - Dallas-Minneapolis-Atlanta, Master Paintings, 1981/1982, Nr. 1; Washington, Places of Delight, 19881989, Nr.6.

Mentioned always as coming from the Pulszky collection (former director of the National Gallery in Budapest), this little painting can be traced back to the Wil- 
helm Koller sale, Vienna in 1872, where it figured as "by an old Italian master before Raphael" as a "Sitting violinist in a landscape, Saturn next to him", [wood, $12,7 \times 19 \mathrm{~cm}] .{ }^{65}$ It is supposed to belong to a series of decorative furniture paintings, like those described in the Life of Giorgione by C. Ridolfi (1648). According to the biographer, Giorgione, after leaving the studio of Giovanni Bellini, painted in the workshop "quadri di divotione, recinti da lettoe gabinetti", and then opening his own studio "rotelle, armari e moltecasse". ${ }^{66}$ On these bed-stands, cupboards, chests, etc., he painted mostly the fables of Ovid, The Golden Age, the Giants falling from Olympus, Deucalion and Pyrrha, Python and Apollo, the story of Venus and Adonis or of Psyche among others.

Unfortunately none of these furniture pictures can be identified with security, though there are several works of this type that came to be connected with Giorgione and his circle by different authors. The Phillips Astrologer is one of them. Because of the corresponding measurements and similar setting, it is generally considered to belong to the same series with two other little paintings, the Leda with the Swan and the Pastoral Scene in the Museo Civico in Padova (Figs. 17-18), and possibly also the Venus and Cupid in the National Gallery, Washington. ${ }^{67}$ But differences in proportions and composition might lead us to question this assumption. The figures in the Padova pictures are seated in the foreground close to the lower edge of the painting. In the Astrologer there is a little distance, the figures are a little larger in proportion to the landscape, the horizon lies higher. The light, the atmosphere, while identical in the two Padova paintings, is different in the Washington piece with a sunset and darker surroundings. The connection is also problematical because of the subjects represented. In the Washington picture we see an old man - Saturn (?) - clad in red, sitting in a meadow, holding an hourglass as if contemplating the passing time. A young person - a woman (?) - next to him is playing the violin. The traditional definition as the Astrologer can only be a convenience title, the accurate interpretation lies certainly more in the line of Allegory of Time, as also suggested by the sunset in the background and the melancholy atmosphere. The two panels in Padova on the other hand seem to have a mythological meaning: Leda with Jupiter in Form of a Swan and the Pastoral Idyll interpreted sometimes as Jason and Hypsipyle or the Finding of Paris. Even less convincing is the suggestion of a connection with the little Venus and Cupid in the National Gallery, Washington (Fig. 19).

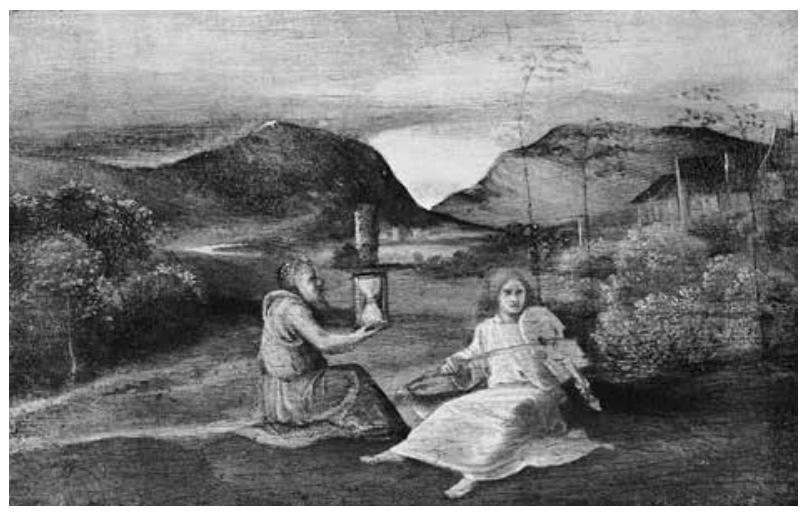

Fig. 16. Allegory of Time (The Astrologer); panel, $19 \times 19.5$ cm; Washington, Phillips Memorial Gallery

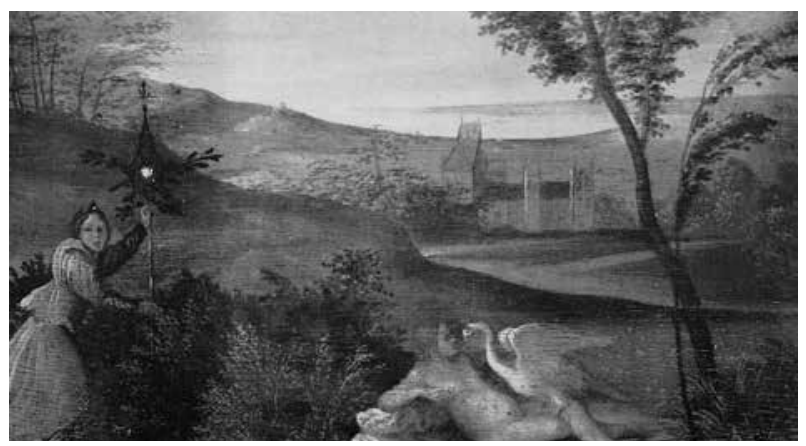

Fig. 17. Leda with the Swan; panel, $12 \times 19 \mathrm{~cm}$; Padova, Museo Civico

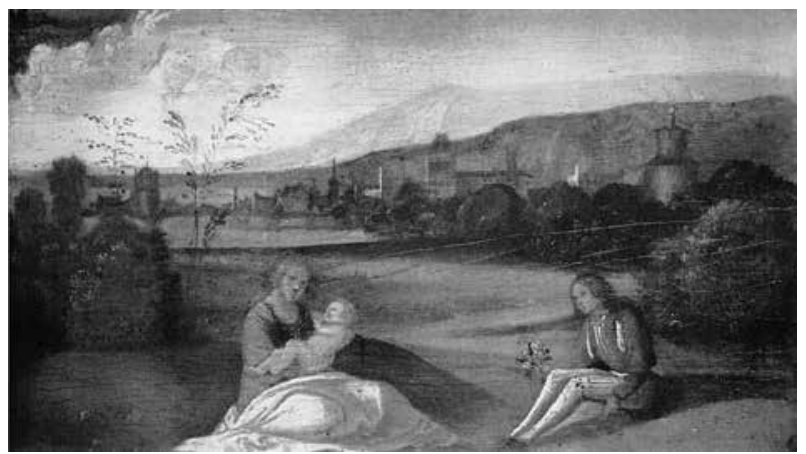

Fig. 18. Pastoral Scene; panel, $12 \times 19 \mathrm{~cm}$; Padova, Museo Civico

What exactly might have been the destination and application of this type of little furniture paintings, we do not know: they did not survive in their original setting. ${ }^{68}$ But all of them, including those reproduced in the drawings of the 1627 catalogue of the Andrea Vendramin collection in Venice, the Idylls, Sacrifices, Fable of Paris, etc. now lost, named as "di Zorzon" have some common traits. ${ }^{69}$ They are mostly small pictures with tiny figures in a rich landscape of an idyllic character, with a mythological or allegorical subject that in most cases cannot be determined with any security. A poetical inspiration of ancient or 
contemporary literature is apparent in all these paintings. There is also - as has been underlined by several authors - an undeniable relation, both in concept and in style, between most of them and a number of works usually ascribed to Giorgione. ${ }^{70}$ The connection of figures and landscape, the elements and the handling of the landscape surroundings, the brushwork, etc. are similar in the paintings of the Allendale group, the Nativity and the Benson Madonna, etc., i.e. works by Giorgione in his early period. We might draw attention among others to the identity of the young man sitting on the right in the Padova Pastoral Idyll and the young king kneeling on the right in the Adoration of the Magi, in the National Gallery, London. It seems to be the same figure, with the same head, in a similar position, as if done after the same model or drawing.

With the given conditions, the fact that furniture paintings were usually workshop productions with very little possibility to demonstrate stronger individual features, the attribution of these little works can hardly be definitive. It is only natural that the Phillips' Astrologer and the group of pictures linked with it have been interpreted in various ways and amid much discussion. They were accepted as by Giorgione by G. M. Richter, A. Morassi, with reservation by L. Coletti, P. Zampetti, T. Pignatti. They have generally been called Giorgionesque by L. Justi, B. Berenson, L. Venturi, etc. The Astrologer or Allegory of Time figures often as by "The Master of the Phillips' Astrologer" with the certainly accurate statement: "These works are of problematic attribution, but they evince a strong affinity with the few authenticated works by Giorgione." ${ }^{\prime 1}$

\section{Venus and Cupid in a Landscape (Fig. 19) \\ Wood, $11 \times 20 \mathrm{~cm}$ \\ Washington, National Gallery of Art, Inv. Nr. 253}

Provenance: Contessa Falier, Asolo near Castelfranco; Count Contini Bonacossi, Florence; 1932 sold to Samuel H. Kress, Washington.

Exhibited: Washington, Places of Delight, 1988-1989, Nr. 7.

A hole, a sort of keyhole, above the center of the panel shows that it must have been part of a chest or box, being evidently a "furniture painting" of the sort we have described above (see Fig. 16). It is sometimes connected (L. Coletti) with the Phillips' Astrologer and the two Padova pictures, as possibly belonging to the

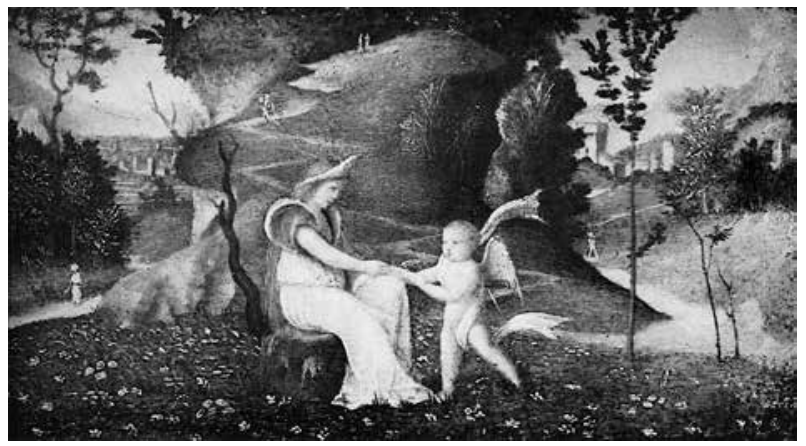

Fig. 19. Venus and Cupid in a Landscape;

panel, $10.6 \times 20.3 \mathrm{~cm}$; Washington, National Gallery of Art

same furniture decoration. But, as already mentioned, the relation is very vague and there is really nothing definite that would link these pieces together. There is no noticeable thematic connection, or compositional concordance. The woman sitting in the middle of a flowering meadow with a child next to her might or might not be Venus, the goddess of love with Cupid: she is not nude, as usually represented, but fully dressed with a peculiar headgear. The proportions and the setting are not the same, and the similarity in size is not enough to establish a convincing connection, as many of the so called furniture paintings are of about the same size. We have to allow for the possibility that not all the small Giorgionesque works can be included in this group of pictures. ${ }^{72}$ Some of them might be fragments; parts cut out from a greater composition, like, for instance, the Paris Found in Mount Ida from the Jewett Mather collection in the Princeton Art Museum. ${ }^{73}$ We have to deal with a rather large number of pictures of diverse origin and destination, coming eventually from different workshops, to be connected in cases with Andrea Previtali, Palma Vecchio, Girolamo Romanino, Bonifazio Veronese, Lorenzo Lotto or others. ${ }^{74}$ Consequently it is not surprising that the Venus and Cupid from Washington was, and still is, variously ascribed to Bellini (by A. Venturi), to Previtali (by F. J. Mather, A. Morassi), or to Giorgione and a follower of his (W. Suida, T. Pignatti), etc.

\section{The Three Ages of Man - Marcus Aurelius with Philosophers (Fig. 20)}

Canvas, $63 \times 80.5 \mathrm{~cm}$

Atlanta, GA., Oglethorpe University Museum, on loan from J. D. and E. Harrington.

Inscribed on the back (in eighteenth [?]-century hand "Carlo Fabrini Dipinse (or Dipinto?)" now covered by new lining. ${ }^{75}$ 


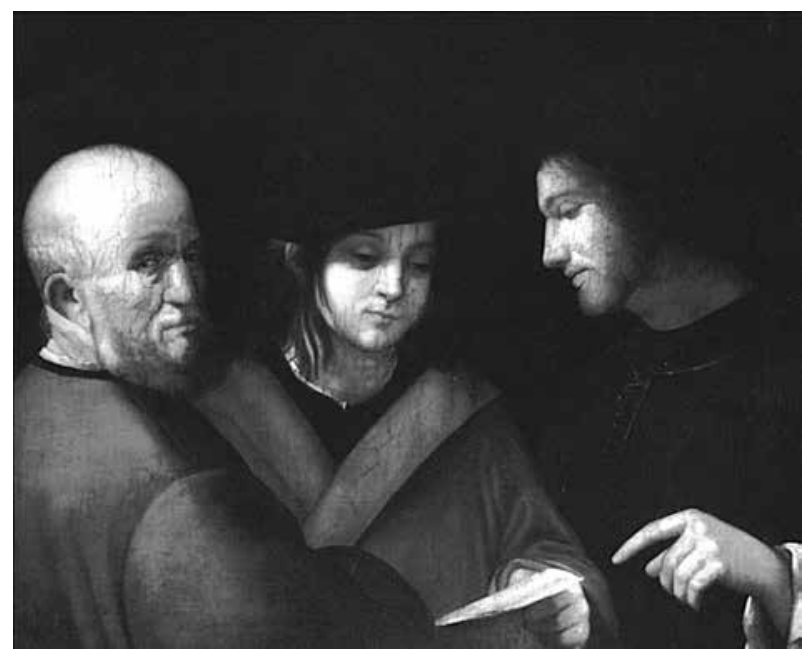

Fig. 20. The Three Ages of Man (Marcus Aurelius with Philosophers); canvas, $63 \times 80.5 \mathrm{~cm}$; Atlanta, GA., Oglethorpe University Museum

Provenance: Sold at sale from Isel Hall, Isel, England, from the collection of Sir Hilton Lawson Bart, July 1960. According to the testimony of family members (Lt. Colonel, J. G. M. Wybergh) in possession of the Lawson and the Leigh families at Isel Hall and Brayton for over 400 years. 1961 bought by J. D. Harrington in Atlanta, GA. ${ }^{76}$

Exhibited: Mobile, AL, Fine Art Museum of the South, 1989-1992; Atlanta, GA., Oglethorpe University Museum, 1993-1994.

The most important data relative to this painting can be found in the scientific reports on pigment analysis by Dr. Walter McCrone, McCrone's Research Institute, Chicago, 1983, 1990-1993. These confirm that all the pigments found in the investigated picture "were in active use by artists at the time of Giorgione (1478-1510)". Further, that there are no pigments in it "that became available during the sixteenth century" or later. The scientific study concludes that "The identity of these pigments, their particle size, the presence of impurities, and the absence of later common pigments also make it extremely unlikely this painting could have been produced later than the early sixteenth century."77

Though the Lawson and Leigh families also owned several other old masters' paintings, this picture in question seems to have never been described or mentioned while in England. Its earlier history is not documented, but there are numerous indications of a strong historical connection between the Leigh family members (John Leigh) and Venice ever since the sixteenth century. ${ }^{78}$
Until 1960, The Three Ages of Man was only known through the widely noted version in the Pitti in Florence.

\section{The Three Ages of Man - Marcus Aurelius with Philosophers (Fig. 21)}

Wood, $62 \times 77.5 \mathrm{~cm}$

Florence, Pitti, Inv. No. 110.

Restored in 1989 by A. del Serra. Recent reflectography investigation shows traces of an underdrawing with the Virgin kneeling before the Child in a landscape, as if a sketchy idea to an Adoration.

Provenance: Collection of Grand Duke Ferdinando di Medici, Florence, Inventario di Quadri ed altro, 1698 c. 22 r. No. 1067, Quadri del R. Palazzo Pitti, cca. 1702-1710 Vol. II. c. 431 r. No. 235, 1185, Inventario de Mobili ... nel Palazzo de Pitti, 1713 c. 31 r. No. 235 with detailed description and measurements as "maniera lombarda," representing The Three Ages of Man. Entered the Medici collection with a few other paintings from the estate of the painter Nicolò Renieri (1591-1667), in whose collection (1663) and at whose auction sale in 1666 it figures as "De Palma Vecchio Un Marco Aurelio quale studia fra due filosofi, mezze figure quanto al vivo, fatto in tavola $4 \times 5$ quarte (cca. $68.5 \times 85.4 \mathrm{~cm}$ )". Earlier probably in the collection of Gabriele Vendramin, Venice, 1567-1569 inventory as "Tre testoni che canta" by Giorgione. $^{79}$

Exhibited: Venice, Giovanni Bellini, 1949; Venice, Giorgione, 1955, No. 41; Venice, Leonardo e Venezia, 1992, No. 66; Florence, "Le Tre eta dell uomo", 1989; Paris, Le siècle de Titien, 1993, No. 21.

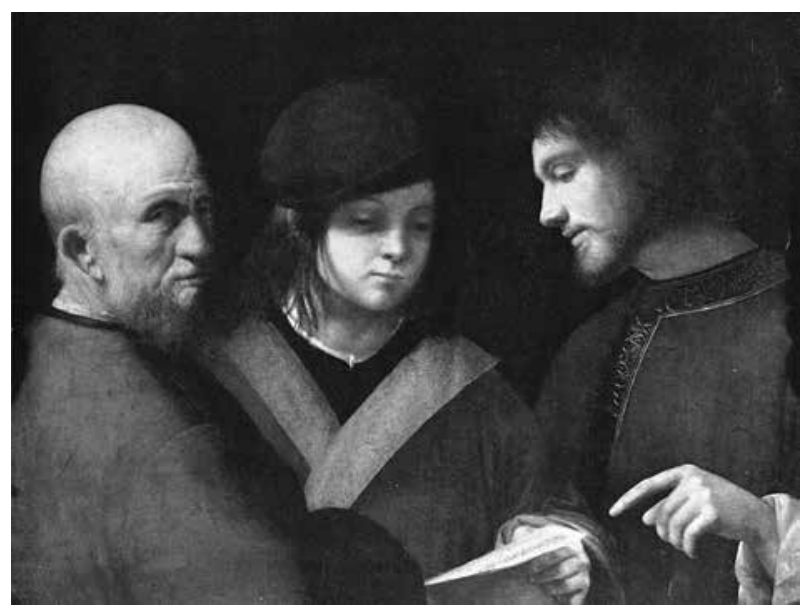

Fig. 21. The Three Ages of Man; panel, $62 \times 77 \mathrm{~cm}$; Firenze, Galleria Pitti 
The provenance of the Pitti Three Ages of Man from the collection of Nicolò Renieri, established in 1978 (K. Garas) seems to be generally accepted by now (see M. Lucco, 1989, A. Ballarin, 1993). ${ }^{80}$ The earlier history of the picture, its connection with Gabriele Vendramin's camerino is still discussed and confused by misunderstandings. The facts and arguments can be summed up as follows. Marcanton Michiel in his description of the Gabriele Vendramin collection in 1530 does not mention the painting with the three half-figures, either because it was not there at that time, or because he did not see everything.

After the death of Gabriele Vendramin (1552) an inventory was made of the "camerino delle anticaglie" in his house at Sta. Fosca in the years 1567-1569. This quotes "Un quadro de man de Zorzon da Castelfranco con tre Testoni che canta" (no frame is mentioned). In another room, a picture "un quadro con tre che canta" (with gilt frame - no author's name), and "un quadreto con tre teste che vien da Zorzi", that is, a painting with three heads after Zorzi - Giorgione - is mentioned. ${ }^{81}$

In 1601, due to a lawsuit, an inventory - published by J. Anderson - was drawn up of some pictures that were taken by one of the Vendramins illegally from the common family heirloom. ${ }^{82}$ This list quotes the following relevant items, without the name of the painters, but with frames and sizes among others: "Un quadro con tre teste" with a gilt frame, "un quadro con tre teste" with an old man, a youth and a woman, and "un quadro con una testa grande e doi altre teste per banda in ambra". The process ended by the paintings being taken back to their original site, and they were kept in accordance with the will of Gabriele Vendramin under seal in the family palace at Sta. Fosca as told in a report of 1615 . Sometime before 1657 , as we know from contemporary sources, the collection was sold by Andrea Vendramin (Zamballotto), and among those who bought the paintings was Nicolò Renieri, famous painter and leading art dealer in Venice. In Renieri's collection, sold in form of a lottery in 1666 , at least some pictures can be traced back as coming from the Vendramin gallery, some of which came, after the death of Renieri, into the possession of the Medici in Florence.

To follow up the fate of the relevant paintings from the Vendramin and Renieri collections is, in most cases, an extremely difficult task, with only slight evidence. In 1978, I tried to connect the Pitti Three Ages of Man - as one of the paintings that came to Florence from Renieri's collection - with the Tre testoni che canta, the Three Heads Singing originally in possession of Gabriele Vendramin and described in the inventory of 1567-1569. J. Anderson, on the other hand, proposed (1978) on basis of the 1601 inventory, to link the Renieri-Pitti painting - because of the gilt frame and the measurements - with the anonymous "quadro con tre che canta", the Three Singers of the 1567-1569 inventory. ${ }^{83}$ This assumption, also accepted by A. Ballarin (1993) leaves several questions open and confronts us with contradictions. First of all, with the "Three heads singing by the hand of Zorzon" in the Vendramin inventory of 1567-1569 there is no frame mentioned, neither gilt nor other. Not all the works listed in this document (thirty-six pieces) are identical with those in the list of 1601, the latter containing a number of manifestly differing items (fifty-nine). The descriptions and data being rather scant, we cannot safely connect or identify the different three-figure paintings quoted in these documents.

There are only a few indications to solve the problem. On the ground of contemporary descriptions and practice, we can deduct that paintings quoted as "Teste" or "Testoni" were bust or half-figure paintings, and that, in the old sources, a clear distinction is made between compositions with singers, people singing, or either musicians, or people playing music. The first type mostly shows figures with scores, music books, the other, people with musical instruments playing or resting. These last types are mentioned usually as "Musici", "Musica", "Piece of music", etc. in old inventories, as for instance the Concert in the Pitti, Florence. Though of course this distinction might not be biding, we must think of the Vendramin Tre testoni che canta as a picture with three half-figure singers without instruments. Now the so called Three Ages of Man composition, with the boy in the middle holding a sheet with notes in his hand, seems to be the only work in the entire Giorgionesque oeuvre which in its subject, as well as in its history fits the conception of the Vendramin painting. ${ }^{84}$ As Gabriele Vendramin, according to the testimony of Marcanton Michiel certainly owned several authentic masterpieces by Giorgione by 1530, the Tempesta, the La Vecchia and, by 1567 , a Pietà, and as he probably acquired them directly from the master, the attribution in his inventory must be taken indeed very seriously. The document consisted of by expert artists, Orazio Vecelli, son of Titian, Jacopo Tintoretto, Alessandro Vittoria, Jacopo Sansovino, based on direct information and solid tradition. It makes a clear distinction between originals, quoting them as "de man de..." or copies and replicas declared as "vien da...", or, if not known, mentions no 
author. Thus it seems reasonable to accept the fact that there was, in possession of the Vendramins, a painting with three half-figures singing, known to be a work by Giorgione, another Three Half-Figures Singing by an unnamed master - perhaps a second version of the former - and, in addition, a painting with three halffigures "after Giorgione". ${ }^{85}$

This rather complicated and in many respects unclear situation leaves the way open to different assumptions. As we have seen above, there is good reason to believe that one of the Three Singers, eventually the one quoted as by Giorgione with the Vendramins', came together with other Vendramin paintings to Nicolò Renieri and at last to the Medici, the Pitti in Florence. According to others (J. Anderson, M. Lucco) this might have been the alternate, anonymous Three Ssingers, in which case the first one seems to have got lost. Given the possibility that those were indeed similar compositions or versions, it must be taken into consideration that one or the other got at some time to England. In fact we know that already in 1619 the British ambassador obtained the permission of the Venetian Council to visit the studio of Andrea Vendramin, the heir of Gabriele, as he was looking for works of art to buy. ${ }^{86}$ There is also the fact that at least one masterpiece from the Vendramin collection was already in England before 1641: Titian's Portrait of the Vendramin Family from the camerino, or "little study" of Gabriele was in possession of the painter Anthonis van Dyck (now in the National Gallery of London). It was reported as for sale from Venice in 1636 by the son of the Earl of Arundel.

Not only the provenance and the history of The Three Ages of Man, but also the question of its subject and its author have been interpreted in various ways and are much discussed. Before entering the Medici gallery in Florence, when it was still in the collection of Nicolò Renieri in Venice (1663, 1666), it figured as "Un Marco Aurelio, quale studia fra due filosofi, mezze figure quanto al vivo" by Palma Vecchio. As demonstrated in my paper at the Convegno of Giorgione in Castelfranco in 1978, this description is in perfect accordance with a passage in the biography of the Roman emperor Marcus Aurelius, the Historia Augusta, published in Venice in 1489, 1516, 1619, etc. There we read, among others, how Marcus Aurelius as a boy of thirteen had already dedicated himself to the life of philosophers, how he took part in inaugurations, where he did not have to be told about the songs beforehand, as he knew them all by heart. His tutors were the stoic philosophers, Apollonius from Khalke- donia and Junius Rusticus. ${ }^{87}$ Not only does this quotation fit perfectly the Three Ages of Man composition - a boy standing between two elder men holding a score but not looking at it - there is also a sort of inscription on the hem of the man's garment on the right showing the Greek letters $\mathrm{K} / \mathrm{L} / \mathrm{K}[\ldots]$ probably as a reference to Khalkedonia. The inscribed type of hem recurs in other paintings by or attributed to Giorgione, for example the Madonna in Oxford (Ashmolean Museum). When the Pitti painting was first mentioned at the end of the seventeenth century in Florence, it was described as representing The Three Ages of Man by an unknown Lombard master. This title remained connected to it throughout the nineteenth and twentieth centuries. It only changed when it was taken by the French from Florence in 1799 and exhibited in the Musée Napoléon in Paris. There it was called "La leçon de musique" or "La leçon de chant" by Giorgione, and was engraved with that title by L. A. Claessens and described at length by Stendhal (1811) who saw it in Paris: "Leçon de musique: ... le maître de musique a reprit l'enfant d'un grand seigneur devant lui...". 88 This interpretation as music lesson or a lesson in singing was accepted lately by a number of scholars, as in perfect accordance with neoplatonic conceptions and motifs.

Both in respect of subject and conception there are a few other paintings that seem to be closely related to The Three Ages of Man and have been discussed on many instances in connection with it: these are the so called Borgherini Portrait in Washington and the Concert in the Royal Collection at Hampton Court (Figs. 22-23). In the double portrait in Washington, the boy on the left, who is holding a compass and a pencil, looks very much like the young Marcus Aurelius in our composition, and the man at his side with

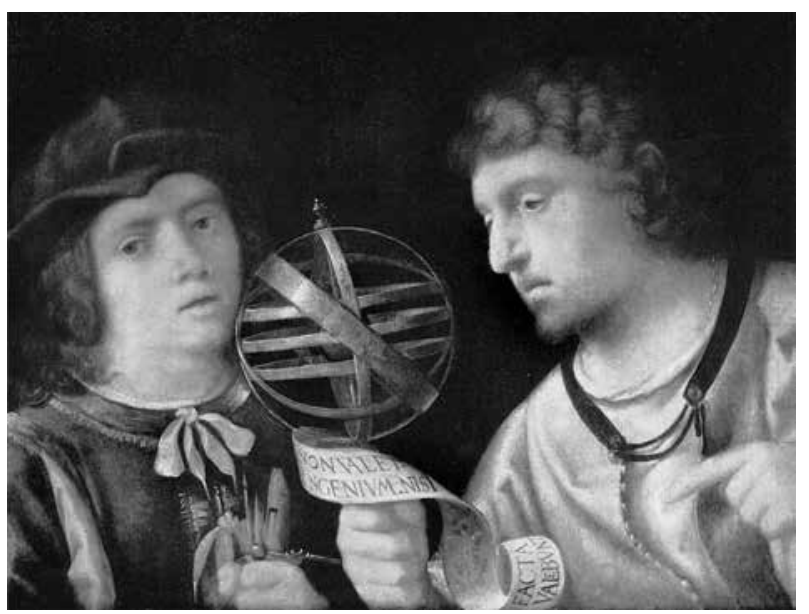

Fig. 22. Borgherini Portrait; canvas, $46.5 \times 59 \mathrm{~cm}$; Washington, National Gallery of Art 


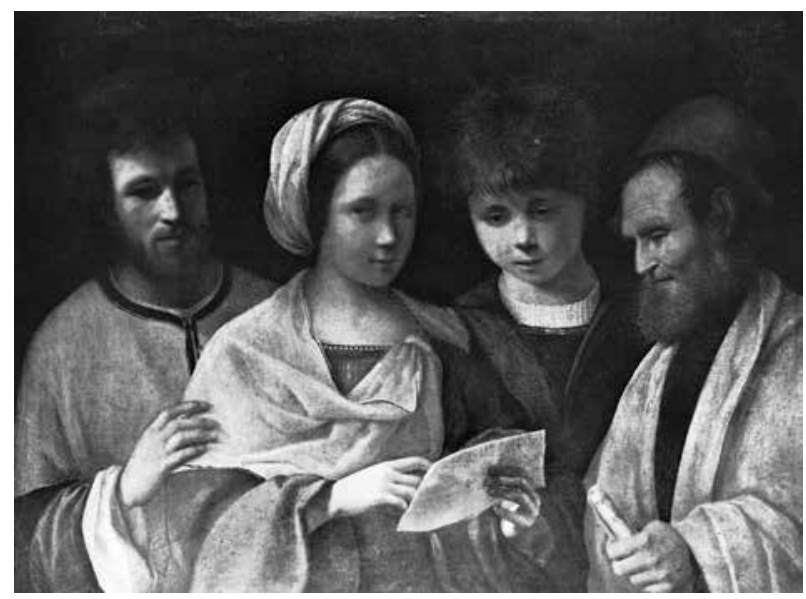

Fig. 23. Concert; canvas, $76 \times 99 \mathrm{~cm}$; Hampton Court Palace, Royal Collection

an orrery (astrolabium) in his hand is very much the same as the eastern philosopher on the right side of the above mentioned painting: his profile, the pointing gesture of his left hand are similar. The Washington portrait came from the F. Cook collection (Richmond, England, 1925) and was supposedly bought in Milan from the heir of the Borgherini family in the eighteenth century. Because of this tradition, it came to be identified with a double portrait of the "young Giovanni Borgherini and his tutor" described by Vasari as a work by Giorgione in possession of the Borgherini in Florence. ${ }^{89}$ Though this origin cannot be verified, the painting representing a boy and his master showing an inscription on a banderole with the moral motto "non valet ingenium nisi facta valebunt" in an act of instruction, certainly belongs to the type of "Unterweisungsbild", instruction painting, half portrait, half genre, rather popular since the turn of the fifteenth century. It followed the Leonardesque conception, cultivated by Giorgione and his circle in half-figure paintings, like the Three Ages of Man or Marcus Aurelius between Philosophers, among others. We might also think of an illustrative-historical interpretation in the case of the so called Borgherini composition: it could be meant to represent the young Alexander the Great as a pupil and his tutor Aristotle. The relation between the two compositions is apparent, even if they are not necessarily by the same hand.

The other half-figure painting that has been connected with this group by different authors, the Concert of Singers in the Royal collection at Hampton Court, shows a woman holding a musical score, with an old man, a boy and a man at her side. The attitudes, the thoughtful atmosphere of the picture, the setting with the four busts close to the foreground, the simple garments varying according to the age of the persons, as well as the facial types and gestures strongly remind one in composition and actors of The Three Ages of Man, and partly also of the double portrait in Washington. Ever since it turned up in the seventeenth century, the Hampton Court Concert went under the name of Giorgione: it was thus engraved in about 1650 by Jeremias Falck, when in Amsterdam in the collection of Gerrit Reynst. After the death of this famous collector, it was presented with the "Dutch gift" by the State of Holland to King Charles II of England. ${ }^{90}$ Its attribution, its eventual connection with the other works quoted above, was and is subject to controversial opinions. They were variously ascribed to the old Giovanni Bellini (R. Longhi, P. Zampetti), to Torbido (G. Fiocco, R. Pallucchini), to Morto da Feltre (L. Coletti), to Domenico Mancini (C. Gamba) or Giorgione and his school (T. Pignatti, A. Morassi). ${ }^{91}$ Even a special master, the "Master of the Three Ages of Man" had been suggested for this group (B. Berenson), though later, the difference in quality between them was consequently underlined. The majority of critics do not believe any more that the Hampton Court Concert could be by the same hand as The Three Ages of Man composition, even though a conceptual and compositional accordance is apparent in all the works of this group. One of the common denominators seems to be the attitude in a rather complicated presentation, a multi-faced and multicoloured content, the interweaving of poetical, philosophical and allegorical meaning. The different titles given to the painting in Florence and Atlanta, The Three Ages of Man, Marcus Aurelius between Philosophers, The Three Singers or the Lesson of Singing are all relevant, they do not exclude each other; we do not have to decide for the one or the other. As with several other works by Giorgione and his circle, the same composition might have different meanings, i.e. literary allusions, as well as reflection on everyday reality, "poesia" and allegorical message. This rather complicated, richly sensitive and intellectually tinted style became most popular in certain Venetian circles in the first decade of the sixteenth century and its leading representative was certainly Giorgione. Some of his most well known masterpieces, The Three Philosophers in Vienna, or the Tempesta in Venice belong to this type of painting. It is by no means clear how much of the content, the subjects and meanings was determined by the customers, the art patrons, the close circle of humanist advisors and dilettanti, and how much of it is due to the painter's own inspiration and inclination. With one topic at least, with one of 
the main "Leitmotifs", the recurrent representation of music, the master's personal attitude and predilection must seriously be taken into consideration. As with a number of other Venetian painters of the period, Sebastiano del Piombo, Pordenone, Titian, etc. music, more exactly playing music had an important role in the life and activity of Giorgione. Vasari described him as an excellent lute player, who was often invited to the gathering of the nobility because of this gift. ${ }^{92}$ There are several paintings of this theme, compositions with music that were painted by him, or were considered for a long time to be his works, like the Concert in the Palazzo Pitti or the Concert Champêtre in the Louvre, Paris, ascribed now by most critics to the young Titian. ${ }^{93}$

All these thematic and conceptual elements connected with The Three Ages of Man seem to be pointing to a close relation with Giorgione, a relation strengthened by further indications and circumstances. We might quote for instance a passage from the treatise of Lodovico Dolce, the Dialogo della pittura (Venice, 1557), where we read about painters, who, having painted a youth, they put an old man or a boy at his side, and having presented a face in profile, they put there, another face "en face" or in three quarter turn. That the description in the Dialogo, where Aretino and Fabrini exchange views on paintings and painters, might have been inspired by existing pictures, eventually Giorgione's, is supported by the next few lines after this passage: "Have they made a man turned with his back, soon they add another showing him in front."94 It mentions a figure striking with a dagger in a vehement movement and grabbing a weapon with force, a description strongly reminding the so called Bravo in Vienna, ascribed to Giorgione, or by others to Titian. Lodovico Dolce also states that in his youth, Giorgione mostly painted half-figure compositions and portraits.

There is also another, hitherto unnoticed indication to Giorgione's Three Ages of Man composition. Speaking of a painting attributed to Giorgione in Genova in the possession of the Cassinelli, Carlo Ridolf in his Maraviglie dell' Arte (Venice, 1648) describes a composition of half-figures representing the symbol of human life. There, next to a nurse holding a child beside a robust man in arms, one can see a young man disputing with philosophers, as well as an old woman and a nude old man with a skull. ${ }^{95}$ The description does not fit any existing or conceivable picture of Giorgione, but seems to have been a compilation of Giorgionesque motifs: the nurse with a child in her arms evoking the Tempest, the old woman eventually
La Vecchia in Venice, the nude old man with the skull evidently originating from the Three Ages by Titian in Edinburgh (Fig. 24), some versions of it ascribed to Giorgione, and the young man disputing with philosophers must have been a reminiscence of the Pitti Three Ages of Man composition. We have to note that all and each of the model paintings used and linked into this compilation seem to have been originally in the Vendramin collection or later with Nicolò Renieri.

We had to deal in detail with all these questions as it could get us closer to the solution of the main problems, those of date and of authorship of the Pitti and Atlanta pictures. In the mass of suggestions, assumptions and controversial opinions, every indication, every point of departure must be used to get results, and there are only few facts that we can rely upon. The indication of external signs, of costume, hairstyle, accessories, gestures belong to these. The expert investigation by one of the leading authorities on historical clothing and textiles, Stella Mary Newton from London, having seen both versions of the composition, declared that the structure of the clothing, its correctness, the folds and shadows show that the picture in America must have been painted after life, around the years of 1505-1506. ${ }^{96}$ The toga of the old man, the garment and cap of the boy in the middle, as well as the green coat of the man on the right with its ornamental hem, all seem to indicate the fashion and style around 1500 in Venice and the Terraferma. The same can be said about the haircut and the beards. Analogies can be found in numerous paintings and engravings of that period. Unfortunately, not much indication can be gained from the only accessory in the composition, the score held by the boy before him. It is evident in both versions that there were some notes on the paper. In the much damaged and restored Florentine painting the lines are visible, but the notes - probably over-painted - are unclear, illegible. On the painting

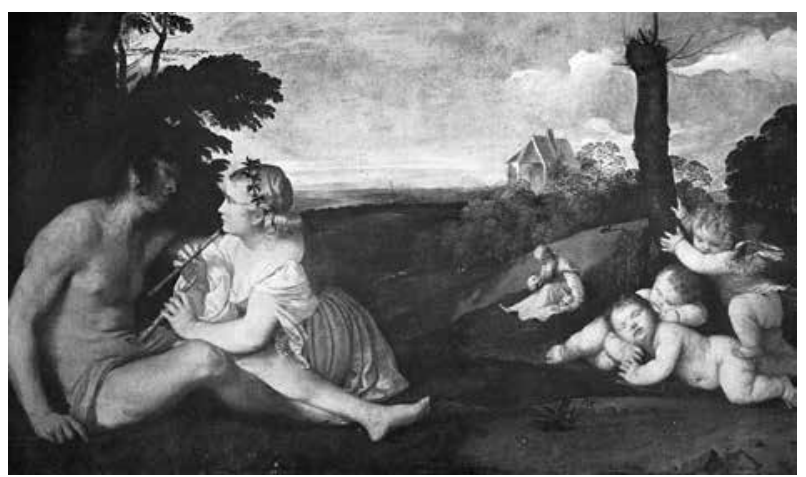

Fig. 24. Tiziano: The Three Ages; canvas, $106 \times 182$ cm; Edinburgh, Scottish National Gallery 
in the USA, the notes - and a clef (?) - seem to appear on the reverse of the paper. As recent research, especially on occasion of the presentation and restoration of the painting in Florence made public in 1989 (M. Lucco) demonstrated that all the elements of the composition, as well as the type of heads and gestures, are in closest relation with the trend of Venetian painting inspired by Leonardo da Vinci, whose influence on Venetian painters of that time especially on Giorgione is a fact already noted and emphasized by the testimony of Vasari. ${ }^{97}$ The mood and atmosphere of the three half-figures interpreted as The Three Ages of Man, as Three Singers or as Marcus Aurelius with Two Philosophers fit perfectly the Leonardesque conception of "the motions of the mind," the intention to represent different human types and characters, contrasting youth and age, beauty and ugliness. More than that, there are undeniable similarities between this composition and some works by Leonardo in single types and figures. The bald man on the left in the Three Ages, the profile head on the right among others are distinctly resembling heads drawn by Leonardo, for instance on the sheet in the Uffizi in Florence, an old man and youth in profile, or the one with five heads, as well as some single head studies in the Windsor Castle collection. This question, the relation to the art of Leonardo, as well as the connection with Dürer in Venice has been investigated from different points of view and by several scholars, but concerning the Three Ages composition there are still open questions to be answered.98

Equally intricate seems to be the problem of the original destination and function of the picture. ${ }^{99}$ It is certainly linked to the development of profane art, of genre and literary subjects in Venetian painting at around 1500, and here again we find a strong affinity with the works and instructions of Leonardo and the inspiration of Lombard painting. Half-figures, connected in action and conversation, have been conceived in Venice mainly after this model in the first place by Giorgione. His part in this field, as innovator and painter of "cose vive e naturali" (Vasari), was praised by almost all critics from Vasari to W. Pater, who expressly called him "the inventor of the genre". ${ }^{100}$ It was in many ways attached to the fact that he mostly worked for private clients; his paintings' designations were, in most cases, not public places but the houses and palaces of the Venetian patricians, men interested in arts, literature and music. ${ }^{101}$

All these considerations and arguments might be of importance in weighing the fundamental question of authorship, in determining Giorgione as the most likely author of the conception and composition of the so called Three Ages of Man in Florence and in the USA. As we have seen above, his name was first connected with the Pitti painting at the end of the eighteenth century, but since that time this attribution was always challenged, as different other masters of the period came to be suggested for it. It is perhaps sufficient if we only quote here the most important suggestions: ${ }^{102}$ it was thought to be by Lorenzo Lotto by F. Inghirami and J. A. Crowe and G. B. Cavalcaselle. M. Logan, L. Venturi, L. Justi, G. Gronau voted for Morto da Feltre, it was attributed to Domenico Mancini by G. Gamba, Pier Maria Penacchi by G. M. Richter. R. Longhi, P. Zampetti, etc. suggested Giovanni Bellini, while B. Berenson suggested an unknown "Master of the Three Ages of Man", accepted by F. Heinemann. G. Fiocco put it close to Torbido, A. Einstein, A. Gentili, etc. named Sebastiano del Piombo as author. But ever since the nineteenth century a number of scholars, i.e. G. Morelli, H. Cook, D. Phillips, W. Suida, A. Morassi, T. Pignatti, A. Ballarin, G. Tschmelitsch or lately, M. Lucco believed it to be a work by Giorgione. This attribution came to be reinforced by a recent development: by the restoration and reflectography tests of the painting in Florence, the appearance of another version in America and its technical analysis, the revised interpretation of the subject, and the exhaustive investigation on provenance. All this led - as A. D. Brown put it (1992) - to a growing consensus in favour of the attribution to Giorgione. ${ }^{103}$ L. Mucchi, L. Magugliani, T. Pignatti, W. Hugelshofer, M. Lucco, etc. support the suggestion that the composition, and eventually the Pitti painting of The Three Ages or Marcus Aurelius is due to Giorgione, while Ch. Hope, A. Gentili, Ch. Hornig still have objections against this assumption. There is also disagreement concerning the quality and merit of the much damaged Florentine painting. As for the newly discovered version in the USA, it had not been known until the 1960s, and although presented at several local exhibitions - in Mobile, AL., Atlanta, GA. - only few experts saw it. Of the few who expressed their opinions, we might quote in the first instance T. Pignatti, who wrote in 1986 that it "can possibly have been done in the strict circle of Giorgione, actually it might have been a replica requested to him and partly painted by some assistant". M. Muraro in a report in 1990 felt strongly that it was a "piece that was entirely made by Giorgione" weighing the possibility of a second version - but still had problems in guaranteeing this attribution. Expert physical analy- 
sis, the scientific test of pigments show unmistakably that it must have been painted at the beginning of the sixteenth century, a date which is in fact entirely in accordance with the other characteristic features style, costume, etc. of the painting. ${ }^{104}$

\section{Portrait of a Man - Terris Portrait (Fig. 25)}

Wood, $30 \times 26 \mathrm{~cm}$

Inscribed on the back: "..15.. Di man de m.ro zorzi da castelfranco"

San Diego, Fine Arts Gallery, Inv. No 41-100

Provenance: 1941 Gift of Anne R. and Amy Putman; New York, Gallery Lilienfeld; Alexander Terris Collection London (by 1937); David Curror, England. ${ }^{105}$

Exhibited: Los Angeles, 1979-1980, No. 9; Paris, Le siècle de Titien, 1993, No. 28.

With the so called Laura in the Kunsthistorisches Museum, Vienna, this painting is one of the exceptionally rare Giorgione's authenticated by an autograph (contemporary) inscription. According to recent research conducted in the Getty Museum in Malibu, the back of the picture shows white gesso remnants all around the edges. The rest of the reverse is dark brown with the cursive inscription on it. Underneath, on the left edge of the reverse, there are traces of a drawing, outlines of figures, probably a Madonna of the Bellinesque-Giorgionesque type. The inscription is very much effaced; the last two numbers are almost invisible. The third one is presumably an "0" (or "1"), the last one is interpreted mostly as " 8 " or " 0 ", that is, the date could be 1508 or 1510 . The name appears in the form used in sixteenth-century documents as "Zorzi da Castel Franco".

The head seen in the painting is clean-shaven, turned to the left, and looking at the spectator. He is of middle age, wearing a black (originally purple according to the restorer) coat open at the neck and showing some of his white shirt. This attire and his long hair falling straight to his shoulders - the "zazerra" - indicate the first decade of the century, a date of about 1510. The same bust seems to be represented in a feeble copy in the Galleria Borghese in Rome (canvas, $38 \times 30 \mathrm{~cm}$.). ${ }^{106}$ The face and position are similar, the hair and the costume are alike, but the bust is larger, and there are slight differences in the proportions, in the eyes and eyelids. The connection is not definite, and since both the author and the model of the Roman

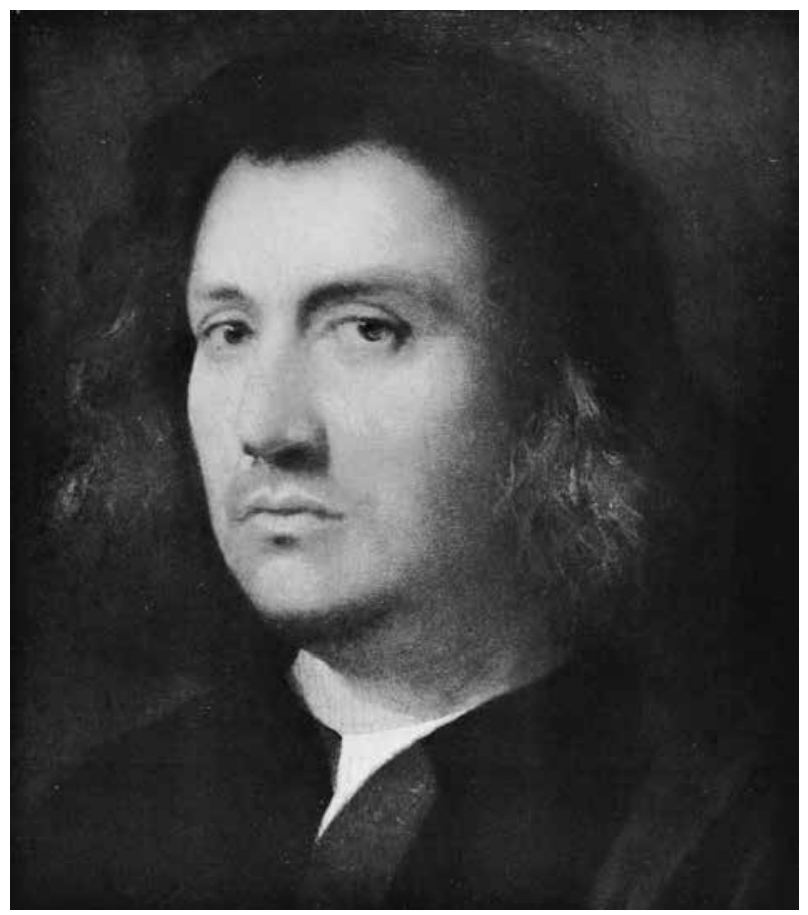

Fig. 25. Portrait of a Man (Terris); panel, $30 \times 26 \mathrm{~cm}$; San Diego, Fine Arts Gallery

painting are unknown, it does not help us much in determining the little portrait in San Diego.

We might get closer to a valid interpretation through a connection, which has been revealed lately. In an article dealing with Dürer and Giorgione a very close similarity between the man in the San Diego portrait and a signed and authentic portrait by Dürer in Genova, Palazzo Rosso could be demonstrated. ${ }^{107}$ In both pictures there are the same facial proportions, the same line of chin, an almost identical mouth, the same, slightly curved nose, deeply set eyes and thick eyebrows. The short neck, the turning of the head and shoulders, the hair are akin. The portrait, dated 1506, and painted by Dürer in Venice, shows the same man somewhat younger, whereas in the Giorgione portrait he seems to be a few years older. The identity of the common sitter remains a conjecture. The fact that Dürer painted him in 1506 while in Venice, suggests a German model or someone connected with the Germans in Venice. On the other hand, we know that Giorgione is supposed to have painted the portrait of a member of the Fugger family. Vasari in his Vite on Giorgione mentions "una testa colorito a olio ritratta di un Todesco di Casa Fuchero" owned by him and kept in his "libro", his book of drawings. ${ }^{108}$ So it seems logical to link these two portraits with one of the Fuggers, eventually with Christopher Fugger, who at that time was living in Venice. 
Whoever might have been the model of the little portrait in San Diego, the inscription, which is generally accepted as contemporary (if not by the master's own hand), and authentic gives a solid base to determine the painting as by Giorgione and the date as $1508-1510$.

Since it was first published by G. M. Richter in 1937, the Terris Portrait has been accepted by most Giorgione experts: by A. Morassi (1942), A. Venturi (1954), L. Coletti (1955), L. Baldass (1955), P. Zampetti (1968), T. Pignatti (1968, 1978), Tschmelitsch (1975), A. Ballarin $(1978,1995)$, R. Pallucchini (1978), Ch. Hornig $(1976,1987)$, L. Mucchi (1978). Only G. Fiocco (1948) and B. Berenson (1957) suggested Palma Vecchio as author. ${ }^{109}$ It is generally accepted as a late work by the master, and as a most important testimony of the style of his last years. ${ }^{110}$ In fact a special interest is paid to this little painting with the contemporary inscription, as Giorgione's activity as a portrait painter, - documented by Vasari and other sixteenth-century authors, for instance, Lomazzo - ${ }^{111}$ is very poorly represented by existing works and almost unknown to us. The portraits quoted in the sources, of Doge Leonardo Loredano, of Catarina Cornaro, of Gonsalvo Ferrante, etc. had disappeared and could not be identified with security. Of those reported in sixteenth-seventeenthcentury inventories and descriptions, there are only very few that survived and could be recognized, like the so called La Vecchia from the possession of Gabriele Vendramin (Venice, Accademia di belle arti) or the Laura from the collection of Bartolomeo della Nave now in Vienna. Though there are several other portraits ascribed to Giorgione in art literature, there is not much agreement concerning them, they are often contested and judged differently by the different scholars, like for instance the Broccardo Portrait in Budapest, or the Nobleman of Venice in the Washington National Gallery $^{112}$ (Fig. 26). It would certainly help if we could say more about the original conditions of producing and installing portraits at the beginning of the sixteenth century in Venice. One should have an answer to the great difference in size (very small and big, life-size portraits), to questions of official and private purposes, the appropriate accessories and attributes, as well as to the problem of "coperta", covers.

\section{Portrait of a Venetian Gentleman (Fig. 26)}

Canvas, $76 \times 67 \mathrm{~cm}$

Inscription on the parapet: $\mathrm{V} \mathrm{VO}$

Washington, National Gallery of Art, No. 369

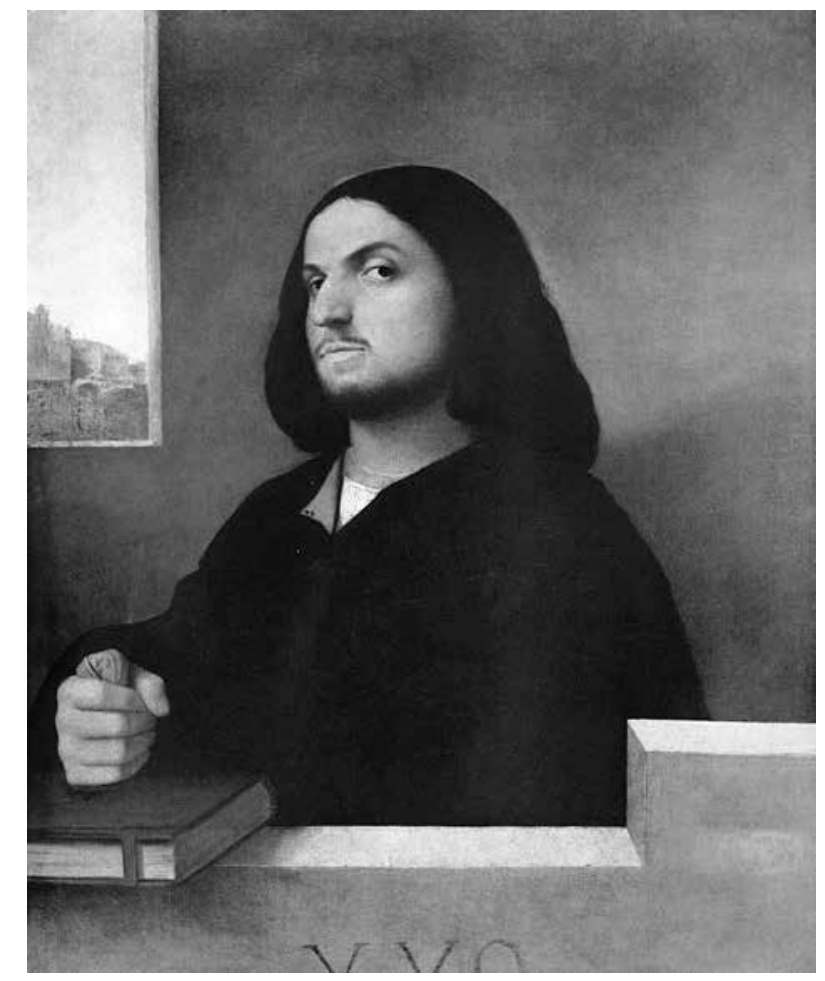

Fig. 26. Portrait of a Venetian Gentleman; panel, $72 \times 64 \mathrm{~cm}$; Washington, National Gallery of Art

Provenance: Probably 1800 John Strange Sale, London as Giorgione Portrait of a Lawgiver; Robert P. Nichols, London; William Graham Sale, London, 1886; Christie's, 1886 Apr. 10 No. 450 as Portrait of a Lawyer by Giorgione; Henry Doetsch Sale, London, Christie's, 1895 June 22 No. 48 as Licinio; George Kemp, Lord Rochdale collection Beechwood Hall, Rochdale, 1897; bought by Joseph Duveen, London, 1918; sold to Henry Goldman, New York, 1922; bought by Samuel H. Kress, Washington 1939. ${ }^{113}$

Exhibited: London, Burlington Fine Arts Club, 1915, No. 41; New York, Metropolitan Museum, 1920; New York, Duveen Galleries, 1924, No. 47; Washington-Venice, Titian, 1990-1991; Paris, Le siècle de Titien, 1993, No. 41 (as Titian)

Until now the first appearance of this portrait was put to the William Graham Sale, London 1886, as Portrait of a Lawyer by Giorgione. This probably traditional designation might well connect it with a painting equally in London, quoted in almost the same way at the sale of John Strange in 1800. Strange's collection came - as well documented - mostly from Venice, where he lived as a British resident between 17701790, and where he acquired his pictures with the help of Giovanni Maria Sasso, an art critic and dealer of great importance. The correspondence of Strange 
and Sasso mentions several works by Giorgione, among them portraits. ${ }^{114}$

Restoration (in 1962 by M. Modestini) and X-ray analysis reveal that the so called Doetsch Portrait in Washington underwent several changes during the working process. Mainly the hand and the accessories were altered. It seems that the right hand first raised over the parapet was holding a sort of a dagger, the hilt of a sword. This was then changed to folded paper or a scroll; now it is grasping a kerchief (not a purse as sometimes suggested). The book on the parapet proved to be a later addition, as possibly the parapet itself. The latest research on Giorgione, X-ray analysis by L. Mucchi confirm that the character of the brushwork is very close to the X-ray results of the San Diego Terris Portrait. Mucchi thinks them typical of Giorgione and rather different from the one used by Titian. ${ }^{115}$

Some conclusions concerning the author and model of the Washington picture might be gained by the accurate interpretation of the garment, the attributes, the background as well as the inscription on the parapet. The clean-shaven, stately man of middle age is wearing a severe black vest - which shows a little of the white shirt on his neck - and is holding a big volume - apparently not a poetry book. All this, but especially the view of the Piazza di San Marco and the Palazzo Ducale on the left in the background suggest that he might be an official, a person of state, eventually a procurator of San Marco, who indeed had to wear black. The view itself is certainly significant and it indicates a connection, which until now has not been closely investigated. An almost identical view, in the same setting and in the same height in the wall opening appears in another Venetian painting of the time, the Madonna by Giorgione in Oxford (Ashmolean Museum - Fig. 27). ${ }^{116}$ The perspective is taken from the same viewpoint, but in the Oxford picture we see the parts of the buildings that follow up to the Piazza and the Palazzo Ducale, including the Prisons. In both paintings the landscape, the water, the sky, etc. are handled in the same way, the figures are located at both instances in the same narrow space between the wall and the parapet. The correspondence goes even further, as the portrait in Washington and the Madonna in Oxford are of about the same size $(75 \times 62.5$ and $75.5 \times 61 \mathrm{~cm})$. The fact that the Madonna is on panel and the portrait on canvas, together with the apparent connections listed, permit the conjecture of an eventual combination of a painting and its cover - timpan - as reported in a number of documents of the early sixteenth century. ${ }^{117}$

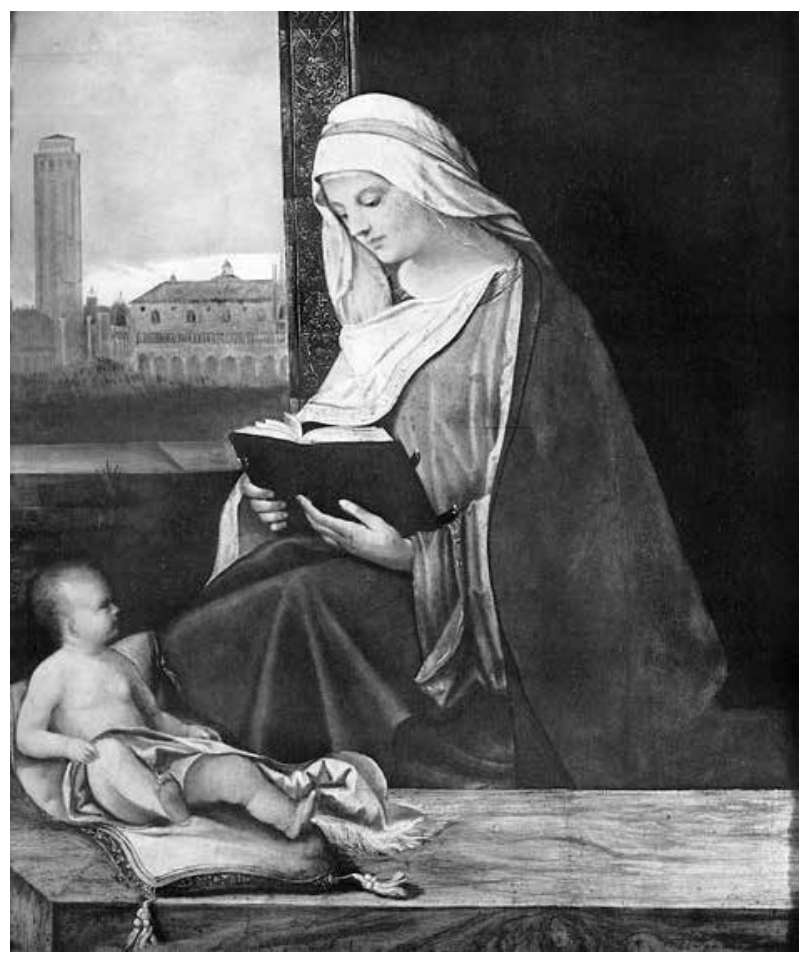

Fig. 27. Madonna Reading; panel, 76×61 cm; Oxford, Ashmolean Museum

The inscription on the parapet in the front, which came out during the restoration, with the majuscule letters VVO has been interpreted together with other similar inscriptions in many different ways. The letters VV on the Portrait of a Young Man by Giorgione in Berlin, the $\mathrm{V}$ on the Broccardo Portrait attributed to Giorgione in Budapest, the V on the Bust of a Woman in White in the Galleria Estense of Modena, Houston and Budapest ascribed to Cariani, the $\mathrm{V}$ on a portrait of Luigi Crasso (now lost), as well as the T V on the Schiavona by Titian and the TITIANVS?? VV on the so called Ariosto, both in London, were all meant as signatures, alluding to the painter's name or his origin, "Venetus". Or else, they were thought to represent the initials of the collector or eventually an "impresa", a motto. ${ }^{118}$ But as they are apparently works by quite different masters, the letters are certainly not indications of the master's names, nor could they generally stand for Venice, Venetus, as we also have two VV letters on a portrait by L. Signorelli, representing Vitellozzo Vitelli, Lord of Montone, not Venice (Collection B. Berenson). They cannot indicate the name of the owner either, as those never occur in this form (in front, on a parapet, etc.) in paintings of the time. Taking into consideration other contemporary inscriptions with letters on different portraits, on medals and other works of art, the interpretation that really fits would 
be that of a motto - or as it was called - an "impresa", in a shortened form. The items quoted above are not necessarily indicating the same motto, the different interpretations suggested until now as for instance "Vivos Vivo", "Virtus Vincit Omnia" might equally be valid in one or the other case. We can add here just one more data to the problem, the hitherto unnoticed quotation from M. Boschini's Carta del navegar pitoresco, Venice, 1660, where talking about portraits by Giorgione in the possession of Prospero Gozi he says: "Ha de quale Virtù vivo un retrato ...". ${ }^{119}$

All the elements of the Washington portrait, the setting and the composition, the fashion of the garment and hairstyle, all seem to indicate a date before or close to around 1510. After that time, the straight long hair, the "zazzera" disappears, men usually wear beards and the open shirt neck is no more in fashion. This of course permits an alternate attribution to Giorgione as well as to Titian, that is, to the late period of Giorgione or to the very young, the early Titian. The discussion concerning authorship has been going on ever since the painting became known in art literature. When Berenson in 1901 first dealt with the portrait then in the H. Doetsch collection, London, he remarked its close connection with the Broccardo Portrait in Budapest and the Young Man in Berlin. He thought it must be "a copy after a lost Giorgione" and he rejected the possibility of Titian's authorship because "none of the portraits ascribed to him betray a style of portraiture at all of this kind". ${ }^{120}$ It was not only the relation with the mentioned works by Giorgione that weighed in favour of the Giorgione attribution for a long time. The composition with the turning of the shoulder and the window opening, the brushwork, the smoothness of the shadows, the colouring led authors like H. Cook, D. Phillips, A. Morassi, T. Pignatti to accept this attribution. G. M. Richter thought it might have been begun by Giorgione and finished by another hand. Lately, as with a number of other works earlier ascribed to Giorgione, opinion among experts prevail that, in spite of Giorgionesque traits, it ought to be considered a work of Titian. ${ }^{121}$ It could have been painted by the latter in the time, when, according to Vasari, close to the style of his master at the age of 18, Titian painted the portrait of a friend of his, a Barbarigo gentleman. As Vasari states, this would have been held to be a Giorgione, if Titian had not put his name on it in the dark (shadow). ${ }^{122}$ Unfortunately this portrait seems to be lost, its identification with any of the known works - as for instance the so called
Ariosto Portrait in London (National Gallery) - has no foundation. There is no authentic portrait by Titian before 1520 , even less before 1510 . To form an idea of his eventual early "likenesses", we have nothing else to rely on but his frescoes in the Santo in Padova or those - known only from engravings - once on the Fondaco dei Tedeschi. This is certainly not enough to make a safe distinction between possible portraits by him or by Giorgione painted in the first decade of the sixteenth century. As H. Wethey put it: "The narrow line of demarcation between Titian and Giorgione is nowhere more vexed than in the field of portraiture, where little agreement among historians and critics has been reached." 123 In the special case of the Washington portrait, the poor state of preservation makes it especially difficult to determine the author: because of the initial changes and repeated restorations, the judgment on quality or eventually on the authorship of more than one master, remains controversial. ${ }^{124}$

\section{Bust of a Woman [Portrait of a Courtesan]} (Fig. 28)

Canvas, transferred from panel, $32 \times 24 \mathrm{~cm}$

According to earlier reports, there has been a cartellino on the back of the painting (now missing) with an inscription (in eighteenth century hand?) "Giorgione". Pasadena, CA. Norton Simon Museum, Nr. 65.1.

Provenance: By 1927 Prince Karl Max Lichnowsky collection, Kuchelna, CSR.; 1929 Paul Cassirer, Berlin; Alfred Mond, First Baronet Melchett, Romsey; Henry Ludwig Mond, Second Baronet Melchett, Olnworth House, Sharnbree; 1964 sold by the Duveen Brothers to Norton Simon. In the catalogue of the exhibition Venetian Tradition?, Cleveland, 1955, a further provenance was suggested: thus the bust would have been in 1876 with James Howard Harris, First Earl of Malmesbury, London, in 1886 with William Graham, London (as by Titian), in 1912, 1914 with Alexander Henderson, Buscot Park, Faringdon, and then bought by Prince Karl Max Lichnowsky, German ambassador in London in 1912-1914. ${ }^{125}$ But this alleged additional provenance is inconsistent with the contemporary report on the Lichnowsky painting. When the bust was first published by L. Baldass (Baldass 1929), and G. M. Richter (Richter 1932; Richter 1939), it was recorded based on family tradition that it was owned by the Lichnowskys probably since the early nineteenth century. ${ }^{126}$ In fact it can be proved that the Female Bust, once with William Graham and Alexander Henderson, was an altogether different work. It can be identified by the description of different 
authors, and what is more, it still exists in the same place, with the heirs of Sir Alexander Henderson, First Baronet of Faringdon, at Lord Farington's in Buscot Park, England. It is a female head in profile, sometimes ascribed to Cariani, but more like the head of one of the mothers in Piombo's Judgment of Salomon in Kingston Lacy. ${ }^{127}$

Exhibited: London, Royal Academy, 1930, No. 387; Toledo, Museum of Art, Venetian Painting, 1940, No. 25; Detroit, Institute of Arts, 1941, No. 58; Baltimore, Giorgione, 1942, No. 58; Venice, Giorgione, 1955, No. 34; Cleveland, Venetian Tradition?, 1956, No. 19.

Title, interpretation and attribution of this little gem of Italian Renaissance painting have undergone various changes in the past. The bust of a young woman in a loose white shirt and green bodice, with a striped blue shawl on the shoulder has been named alternately a Courtesan, a Venetian Girl, Portrait of a Woman, etc. ${ }^{128}$ Due to a wreath of tiny white flowers (myrtle?) on her forehead, she has even been connected with theatrical presentation. In fact her hairdo and the ornaments exist on several pictures and portraits by Lombard and Venetian masters from the early sixteenth century, for instance on the frescoes of the Fondaco or the Santo by Titian, on his Three Ages of Man in Edinburgh, on portraits by Boltraffio, Ambrogio da Predis or Bartolomeo Veneto. The striped scarf, on the other hand, seems to be rather unusual. We do not find it on portraits, but eventually on paintings with the Repentant Magdalene, the Adulteress, etc., that is, representations of women in biblical context. These might be rather significant elements in determining the Pasadena painting's subject, its origin and destination. It is probably not an individual, independent portrait; the attitude, the garment and the small size speak against this assumption. It does not look like the half portrait, half genre pictures of courtesans by Palma Vecchio or Paris Bordone. ${ }^{129}$ We cannot exclude that it is a fragment, part of a greater composition, like the Head of a Man from the Sachs collection that was originally part of the Adulteress ascribed to Giorgione or to Titian in the Art Gallery in Glasgow. To cut out pieces of paintings - either because they were ruined, or in view of greater profit - has been a usual practice of the art market ever since the seventeenth century. Linked with the problem of fragment is the fact that the Female Bust in Pasadena, though on canvas, shows craquelures typical of panel paintings. It was supposed that it had been transferred from wood to canvas, or, as G. M. Rich-

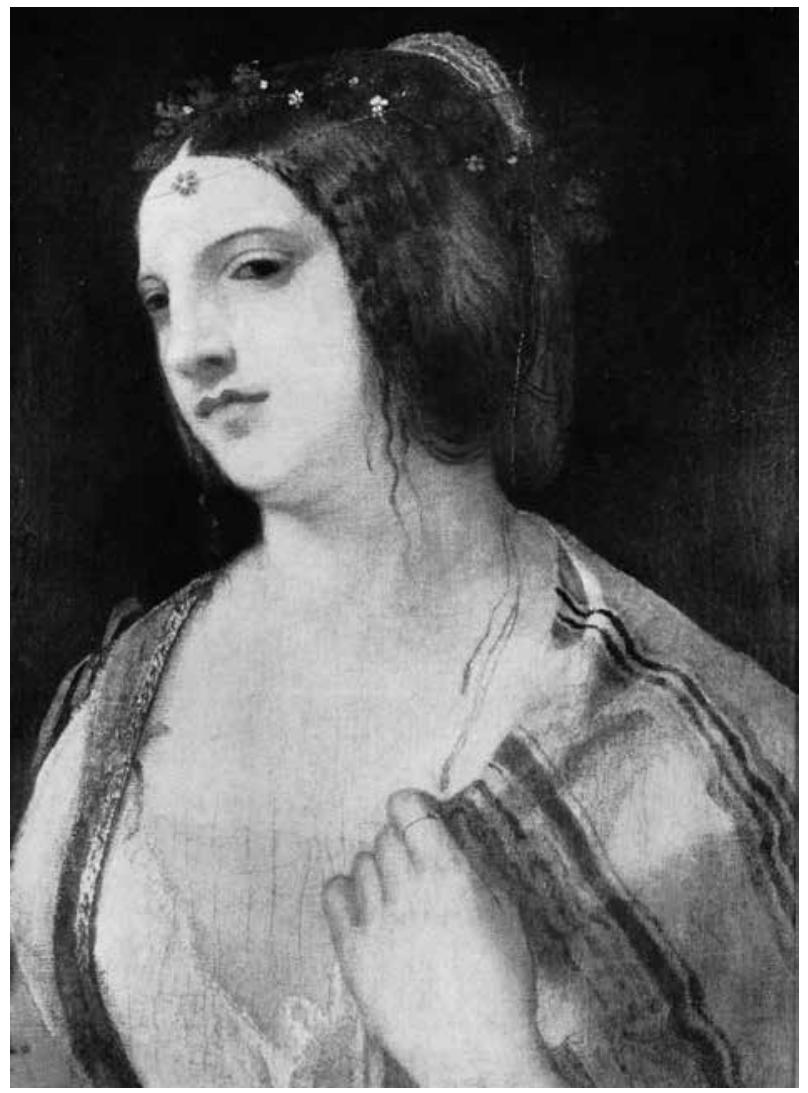

Fig. 28. Bust of a Woman (Courtesan); canvas, $32 \times 24 \mathrm{~cm}$; Fullerton (CA), Norton Simon Museum of Art

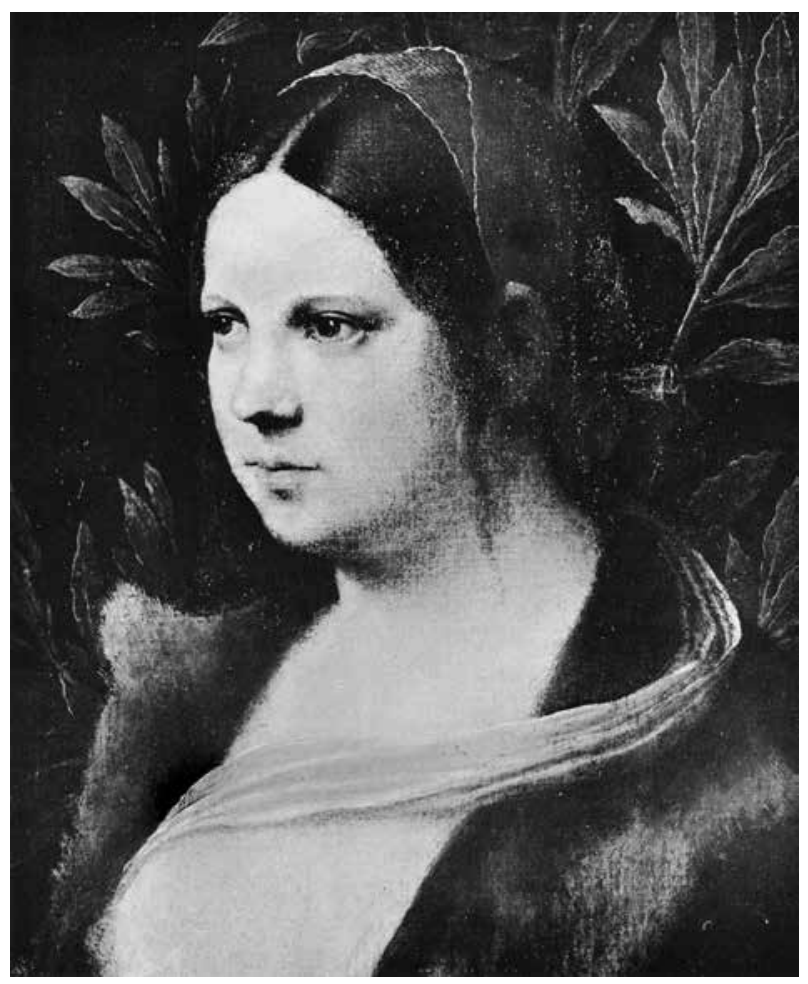

Fig. 29. Laura; canvas on panel, $41 \times 33.5 \mathrm{~cm}$; Vienna, Kunsthistorisches Museum 
ter suggested, it was canvas pasted on wood, like the Laura in Vienna (Fig. 29), which in many respects is similar to this bust.

A female bust, the head crowned with a wreath, occasionally named Laura and sometimes attributed to Giorgione, is listed on several instances and in different versions in art literature. ${ }^{130}$ This popular type is not like the Vienna Laura, the Pasadena Female Bust or the Laura we know only after an engraving made by Wenzel Hollar in 1650 after Giorgione. It represents a young woman turned to the left but looking at the spectator holding sometimes a twig of laurel in her right hand, or wearing a wreath of laurel on her hair which falls straight on her shoulders (see for instance Fig. 30). Sometimes she is represented with a little boy at her side (see Brooklyn Museum, New York). This type of bust, which had on occasions been confused with the Head now in the Norton Simon Museum, exists in at least nine versions. It is a distinctly Palmesque character occasionally ascribed to D. Mancini, G. Cariani or to Bocaccino.

When the Pasadena Bust came to be known in art history, it was first published by L. Baldass as a work by Giovanni Cariani. At the Italian Art Exhibition in 1930 in London, it was attributed to Titian by B. Berenson and W. Suida. Soon it came to be ascribed to Giorgione by G. M. Richter (1937), an attribution accepted by L. Coletti, R. Pallucchini, L. Magugliani, etc. Lately more and more scholars, like A. Morassi, T. Pignatti, F. Valcanover, etc. are in favour of an attribution to Titian. This change of opinion is partly based on the painting's apparent relation with the Glasgow Adulteress, an important work, earlier generally ascribed to

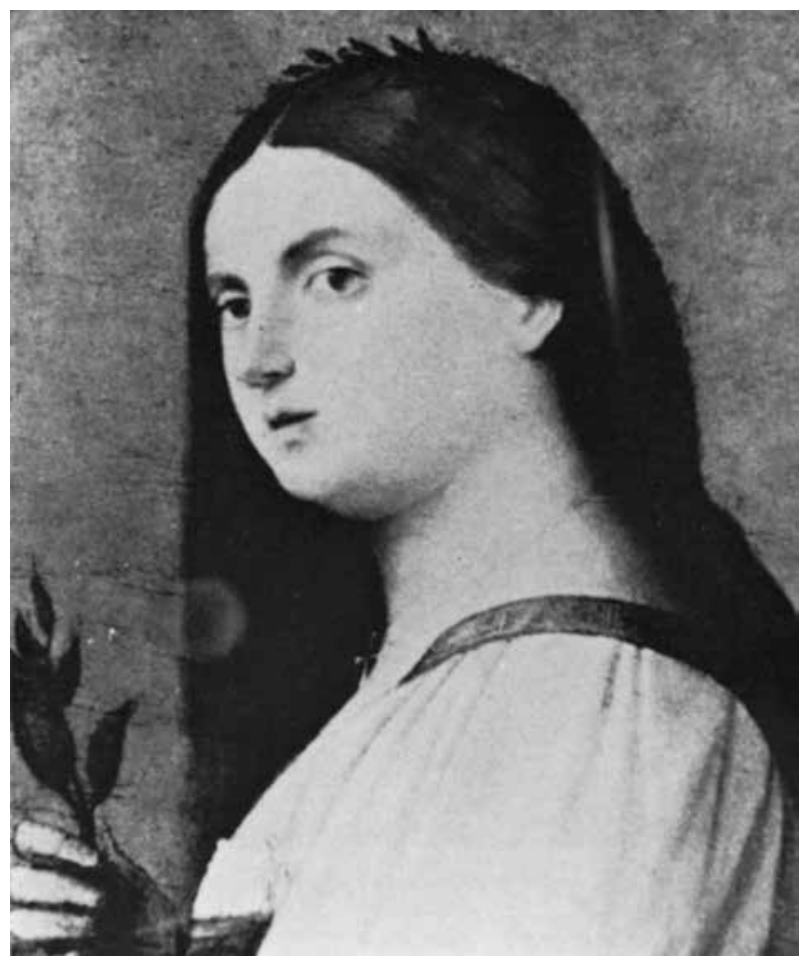

Fig. 30. Female Portrait; panel, $33.4 \times 28.3 \mathrm{~cm}$; Washington, Howard University, Kress collection

Giorgione, but considered nowadays by most authors as belonging to the oeuvre of the young Titian. ${ }^{131}$ The fundamental question, the distinction between the works of these two Venetian masters in the first decade of the sixteenth century still offers unsolved problems. In some cases, like the little Head in Pasadena, the close scrutiny and confrontation of arguments might give more weight to the probability of Giorgione's authorship. ${ }^{132}$

\section{BIBLIOGRAPHY}

Alsop 1942 - Alsop, J.: The Rare Art Traditions: The History of Art Collecting and Its Linked Phenomena, New York, 1942. ANDERSON 1977 - ANDERSON, J.: «Christ Carrying the Cross» in San Rocco: Its Commission and Miraculous History, Arte Veneta XXXI. 1977. 186-188.

ANDERSON 1979 - ANDERSON, J.: A Further Inventory of Gabriel Vendramin's Collection, The Burlington Magazine CXXI. 1979. 639-648.

ANDERSON 1979A - ANDERSON, J.: L'année Giorgione, Revue de l'Art 43. 1979. 83-90.

ANDERSOn 1979B - Anderson, J.: The Giorgionesque Portrait: from Likeness to Allegory, in Giorgione 1979. 153-158.

Anderson 1985 - Anderson, J.: O. Mündler and His Travel Diary, The Walpole Society, Vol. II. 1985.

Art Treasures 1854 - Art Treasures in Britain, London, 1854. II. BALDASS 1929 - BALDASS, L.: Ein unbekanntes Hauptwerk des Cariani. Studie über den Entwicklungsgang des
Künstlers, Jahrbuch der Kunsthistorischen Sammlungen in Wien N. F. III. 1929. 91-100.

BALDASS-Heinz 1969 - BALDASS, L. - HeInZ, G.: Giorgione, Wien, 1969

BALlarin 1979 - BALlarin, A.: Una nuova prospettiva su Giorgione: la ritrattistica degli anni 1500-1503, in Giorgione 1979. 227-252.

Ballarin 1983 - Ballarin, A.: Giorgione e la compagna degli amici: il doppio ritratto "Ludovisi", in Storia dell arte italiana II. Dal Medioevo al Quattrocento, Torino, 1983. 479-541.

BALLARIN 1993 - BALLARIN, A.: Une nouvelle perspective sur Giorgione: les portraits des années 1500-1509, in Titien 1993. 281-294, 309-313.

BAnZato 1988 - BAnZATo, D.: La Quadreria Emo Capodilista, Padova, 1988 
Battilotti-Franco 1978 - Battilotti, D. - Franco, M. T.: Regesti di committenti e dei primi collezionisti di Giorgione, Antichitá Viva 18. 4-5. 1978. 58-86.

Behrman 1980 (1952) - Behrman, S. N.: Duveen, London, 1980 (1952)

Berenbaum 1977 - Berenbaum, L.: Giorgione's Pastorello Lost and Found, The Art Journal 37. 1977. No. 1. 22-27.

Berenson 1901 - Berenson, B.: The Study and Criticism of Italian Art, London, 1901.

Berenson 1957 - Berenson, B.: Italian Pictures of the Renaissance: Venetian School, London, 1957.

Borenius 1923 - Borenius, T.: The Picture Gallery of Andrea Vendramin, London, 1923

Brandolese 1797 - Brandolese, P.: Pitture, sculture ed architetture di Padova, Padova, 1797

BROSCHINI 1660 - BROSCHINI, M.: La carta del navegar pittoresco, Venezia, 1660.

Brown 1979 - Brown, D. A.: Berenson and the Connoisseurship of Italian Painting, exhibition, National Gallery, Washington, 1979.

Brown 1983 - Brown, D. A.: Raphael and America, Washington, 1983

Brown 1992 - Brown, D. A.: Il Cenacolo di Leonardo: la prima eco a Venezia, in Leonardo e Venezia, eds. Marani, P. C. - Nepi Scirè, G. (exhibition catalogue: Venezia), Milano, 1992. 85-96.

CAMPORI 1870 - CAMPORI, G.: Raccolta di cataloghi ed inventari inediti, Modena, 1870.

CARTER 1925 - CARTER, M.: Isabella Stewart Gardner and Fenway Court, Boston - New York, 1925.

Chronique 1866 - Chronique, documents, faits divers, Revue Universelle des Arts XXIII. 1866. 65-68.

Constabe 1964 - Constabe, N. G.: Art Collecting in the USA, London, 1964.

Coletti 1955 - Coletti, L.: Tutta la pittura di Giorgione, Milano, 1955.

Cook 1900 - Cook, H.: Giorgione, London, 1900; $1904^{2}$

Cox 1913 - Cox, K.: On Certain Portraits Generally Ascribed to Giorgione, Art in America 1. 1913. 115-120.

Crow-Cavalcaselle 1871 - Crow, J. A. - CavalCaselle, G. B., The History of Painting in North Italy, London, 1871.

DÉDÉYAN 1981 - DÉDÉYAN, Ch.: Giorgione dans les lettres françaises, in Giorgione 1981. II. 659-746.

Della Lena 1967 - Della Lena, G.: Esposizione istorica dello Spoglio che di tempo in tempo si fece di Pitture in Venezia, in Studies in Renaissance and Baroque Art Presented to Anthony Blunt, ed. Haskell, F., London, 1967. 173-178.

Della Pergola 1954 - Della Pergola, P.: Un quadro de man de Zorzon de Castelfranco, Paragone V. No. 49. 1954. 27-35.

Della Pergola 1955 - Della Pergola, P.: Galleria Borghese, I dipinti, Vol. I., Roma, 1955.

Della Pergola 1957 - Della Pergola, P.: Giorgione, Milano, 1957.

DolCe 1557 (1891) - DolCE, L.: Dialogo della Pittura intitolato l'Aretino, Venezia, 1557, ed. Vienna, 1891.

Douglas 1949 - Douglas, R. L.: Giorgione's later period, Connoisseur CXXIV. 3. 1949. 5-7.

Early Venetian 1895, 1912 - Early Venetian Paintings, New Gallery, London, 1895, 1912.
EGAN 1961 - EGAN, P.: "Concert" scenes in musical paintings of the Italian Renaissance, Journal of the American Musicological Society XIV. 1961. 184-195.

Einstein 1949 - Einstein, A.: The Italian Madrigal, Princeton, 1949

Finley 1973 - Finley, D. E.: A Standard of Excellence. Andrew W. Mellon Founds the National Gallery of Art at Washington, Washington, 1973.

Fiocco 1943 - FIocco, G.: Giorgione, Hamburg-Roma 1943.

FletCher 1971 - Fletcher, J. M.: Isabella d'Este and Giovanni Bellini's 'Presepio,' The Burlington Magazine CXIII. 1971. 703-713.

FOMICIOVA 1979 - Fomiciova, T.: Giorgione e la formazione della pittura di genere nell'arte veneziana del XVI secolo, in Giorgione 1979. 159-164.

Four Centuries of Venetian Painting, exhibition guide, The Toledo Museum of Art, 1940.

Francis 1956 - Francis, H. S.: The Venetian Tradition, Cleveland, 1956.

Frederiksen-Zeri 1972 - Frederiksen, B. B. - Zeri, F.: Census of Pre-Nineteenth Century Italian Paintings in North American Public Collections, Cambridge, 1972.

Frick Collection 1968 - The Frick Collection, an Illustrated Catalogue II. Paintings. French, Italian and Spanish, New York, 1968

GAMBA 1949 - GambA, C.: Contributo al la conoscenza di Domenico Mancini, Critica d'Arte VIII. No 3. 1949 211-217.

GARAS 1964, 1965, 1966 - GARAS, K: Giorgione et Giorgionisme au XVII. siècle I., II., III. Bulletin du Musée Hongrois des Beaux Arts 25. 1964. 51-80; 27. 1965. 33-58; 28. 1966. 69-93.

GARAS 1967, 1968 - GARAS, K.: Die Entstehung der Galerie des Erzherzogs Leopold Wilhelm: Das Schicksal der Sammlung Erzherzogs Leopold Wilhelm, Jahrbuch der Kunsthistorischen Sammlungen in Wien LXIII. 1967. 3980; LXIV. 1968. 181-278

GARAS 1972 - GARAS, K.: Bildnisse der Renaissance II. Dürer und Giorgione, Acta Historiae Artium XVIII. 1972. $125-135$.

GARAS 1979 - GARAS, K.: Giorgione e il Giorgionismo: ritratti e musica, in Giorgione 1979. 165-170.

GARAS 1981 - GARAS, K.: Italian Renaissance Portraits, Budapest, 1981

Gentili 1988 - Gentili, A.: Da Tiziano a Tiziano. Mito e Allegoria nella pittura veneziana del Cinquecento, RomaMilano, 1988

GibBOns 1978 - GiBBONS, F.: Further Thoughts on the Allendale Nativity, Studies of the History of Art VIII. 1978. 23-34.

Gilbert 1991 - Gilbert, C. E.: Newly Discovered Paintings by Savoldo in Relation to Their Patronage, Arte Lombarda 96/97. 1991. 29-46.

GimPEl 1966 - GimPel, R.: Diary of an Art Dealer, New York, 1966.

Giorgione, Guida alla mostra: I tempi di Giorgione, Castelfranco Veneto, 1978

Giorgione 1979 - Giorgione: Atti del convegno internazionale di studio per il $5^{\circ}$ centenario della nascita, 29-31 Maggio 1978, eds. Pallucchini, R. et al., Comitato per le 
celebrazioni Giorgionesche - Comune di Castelfranco Veneto, Banca Popolare di Asolo e Montebelluna, 1979. Giorgione 1981 - Giorgione e l'umanesimo veneziano, actes de la conférence de la Fondation Giorgio Cini à Venise, ed. Pallucchini, R., Firenze, 1981.

Giorgione a Venezia, Gallerie dell'Accademia, Venezia, 1978. Giorgione e la cultura Veneta tra '400 e'500. Mito, allegoria, analisi iconologica, Atti del Convegno, Roma - novembre 1978, Roma 1981

Goffen 1989 - Goffen, R.: Giovanni Bellini, New Haven London, 1989.

Goldberg 1983 - Goldberg E. L.: Patterns in Late Medici Patronage, Princeton, 1983

GRABSKI 1990 - Opus Sacrum. Catalogue of the Exhibition from the Collection of Barbara Piasecka Johnson, ed. GRABSKI, J. 1990.

GRAHAM 1993-1994 - Giorgione's Painting of "The Three Ages of Man (Marcus Aurelius between Philosophers)" - A Critical Study, ed. Graham, L., Antioch, 1993, revised 1994.

Gronau 1911 - Gronau, G.: Giorgione, Berlin-Stuttgart, 1911.

Grummond 1975 - Grummond, N. T. de: VV and Related Inscriptions in Giorgione, Titian and Dürer, The Art Bulletin LVII. 1975. 346-356.

HADELN 1909 - Hadeln [E. V.]: Zum Datum der Bella Tizians, Repertorium für Kunstwissenschaft XXII. 1909. 69-71.

Hadley 1987 - Hadley, R. van N.: The Letters of Bernard Berenson and Isabella Stewart Gardner, Boston, 1987.

HASKell 1967 - HaSkell, F.: Some Collectors of Venetian Art at the End of the Eighteenth Century, in Studies in Renaissance \& Baroque Art Presented to Anthony Blunt on His 60th Birthday, eds. Courtauld, J. et al., London New York, 1967. 173-178.

Haskell 1980 - Haskell, F.: Rediscoveries in Art. Some Aspects of Taste, Fashion and Collecting in England and France, London, 1980 (1976).

HASKELl 1981 - HASKELl, F.: La sfortuna critica di Giorgione, in Giorgione 1981. II. 583-614.

HaSkell 1987 - HASKell, F.: Past and Present in Art and Taste, Selected Essays, New Haven - London, 1987.

Heinemann 1962 - Heinemann, F.: Giovanni Bellini e i Belliniani, Venezia, 1962.

Held 1961 - Held, J. S.: Flora, Goddess and Courtesan, in Essays in Honor of Erwin Panofsky, ed. MeIss, M., New York, 1961. I. 201-218.

Hendy 1931 - Hendy, Ph.: Catalogue of the Exhibited Paintings and Drawings, The Isabella Stewart Gardner Museum, Boston, 1931.

Hess 1955 - Hess, G. A.: Italian Renaissance Paintings with Musical Subject, New York, 1955.

Hind 1948 - Hind, A. M.:Early Italian Engravings, London, 1948.

Hoet-Terwesten 1752-1770 - Hoet, G. - Terwesten, G.: Catalogus of Naamlyst van Schilderyen, St. Gravenhage, I-III. 1752-1770.

HOlBERTON 1985-1986 - HolberTon, P.: La bibliotechina e la raccolta d'arte di Zuanantonio Venier, Atti dell'Istituto Veneto di Scienze, Lettere ed Arti, CXLIV. 1985-1986. 173-193

Hornig 1980 - Hornig, Ch.: Unterzeichnungen Giorgiones, Pantheon XXXVIII. 1980. 46-49.
Hornig 1987 - HoRniG, Ch.: Giorgiones Spätwerk, München, 1987.

Hornig 1992 - Hornig, Ch.: Giorgione oder nicht? Mit einem Verzeichnis der abzuschreibenden Gemälde, Pantheon L. 1992. 46-54.

HugELSHOFER 1971 - HugELSHOFER, W: A propos Giorgione, in Studi di storia dell arte in onore di Antonio Morassi, Milano, 1971.

Italian Art 1200-1900. An Illustrated Souvenir of the Exhibition of Italian Art at Burlington House London, 1930.

Italian Primitives 1972 - Italian Primitives. The Case History of a Collection and Its Conservation. An Exhibition Celebrating the Centenary of Yale University's Acquisition of the Jarves Collection, Yale University Art Gallery, New Haven, 1972.

JafFe 1975 - JafFe, J. B.: John Trumbull, Patriot, Artist of the American Revolution, New York - Boston, 1975.

Jarves 1855 - Jarves, J. J.: Art Hints. Architecture, Sculpture and Painting, New York, 1855.

Jarves 1861 - Jarves, J. J.: Art Studies. The Old Masters of Italy, New York, 1861.

Justi 1908 - Justi, L.: Giorgione, Berlin, 1908

Lavin 1975 - Lavin, M. Aronberg: Seventeenth Century Barberini Documents and Inventories of Art, New York, 1975.

Leonardo \& Venezia 1992 - Leonardo \& Venezia, Palazzo Grassi, Venezia, catalogo della mostra, Milano, 1992.

LeVI 1900 - LeVI, G. A.: Le collezione veneziane d'arte e di antichità dal secolo XIV. ai nostri giorni, Venezia, 1900.

LogAN 1979 - LogAn, A. M.: The Cabinet of the Brothers Gerard and Jan Reynst, Amsterdam - Oxford - New York, 1979.

Lomazzo 1584 (1973-1974) - Lomazzo, G. P.: Trattato dell'arte della pittura, scoltura, et architettura, Milano, 1584, in: Scritti sulle arti, ed. Ciardi, R. P., Firenze, 1973-1974. II. 7-589.

Lucco 1989 - Lucco, M.: Le cosidette "Tre età dell'uomo" di Palazzo Pitti, Le Tre età dell'uomo della Galeria Palatina, Firenze, 1989

Lucco-VolPi 1980 - Lucco, M. - VolPi, C.: L'opera completa di Sebastiano del Piombo, Milano, 1980.

Magugliani 1970 - Magugliani, L.: Introduzione a Giorgione ed alla pittura veneziana del Rinascimento, Milano, 1970.

MAther 1936 - MAther, F. J.: Venetian Painters, Holt, 1936.

McCrone 1994 - McCrone, W. C.: A Scientific Study of "Marcus Aurelius between Philosophers", The Microscope XLII. 3. 1994. 111-119.

Michiel 1888 - Michiel, M.: Notozia d'opere del disegno. Der Anonimo Morelliano, ed. Frimmel, Th., Wien, 1888.

Miller 1966 - Miller, L. B.: Patrons and Patriotism. The Encouragement of the Fine Arts in the United States, 17901860, Milano, 1966.

Morassi 1942 - Morassi, A.: Giorgione, Milano, 1942.

Morassi 1951 - Morassi, A.: The Ashmolean 'Madonna Reading' and Giorgione's Chronology, The Burlington Magazine XCIII. 1951. 212-216.

MuCCHI 1978 - MuCCHI, L.: Caratteri radiografici della pittura di Giorgione. I tempi di Giorgione, Firenze, 1978.

Newton 1988 - Newton, S. M.: The Dress of the Venetians, 1495-1525, Aldershot, 1988

Norton Simon Museum 1980 - Selected Paintings of the Norton Simon Museum, Pasadena, London, 1980. 
Pallucchini 1949 - Pallucchini, R.: Un nuovo Giorgione a Oxford, Arte Veneta III. 1949. 178-180.

Pallucchini 1959-1960 - PAllucchini, R.: Contributi alla pittura veneta del Cinquecento, Arte Veneta XIII-XIV. 1959-1960. 39-61.

PAllucChini 1962 - PALlucChini, R.: Il restauro del ritratto di gentiluomo veneziano K. 475 della National Gallery of Art di Washington, Arte Veneta XVI. 1962. 234-237.

Pallucchini 1969 - Pallucchini, R.: Tiziano, Firenze, 1969.

Pater 1959 (1873) - Pater, W.: The Renaissance. Studies in Art and Poetry, New York, 1959 (1873).

Pedretti 1979 - Pedretti, C.: Ancora sul rapporto Giorgione-Leonardo e l'origine del ritratto di spalla, in Giorgione 1979. 181-185.

Pedrocco 1990 - Pedrocco, F.: Iconografia delle cortigiane. La Cortigiane di Venezia, Catalogo della Mostra, Venezia, 1990.

Phillips 1937 - Phillips, D.: The Leadership of Giorgione, Baltimore, 1937.

Phillips 1970 - Phillips, M.: Duncan Phillips and His Collection, Boston-Toronto, 1970.

Phillips Collection 1981-1982 - Master Paintings from the Phillips Collection, San Francisco - Dallas-MinneapolisAtlanta, 1981-1982.

Pignatti 1969 - Pignatti, T.: Giorgione. Catalogo ragionato, Venezia, 1969

Pignatti 1975 - Pignatti, T.: Il Paggio di Giorgione, Pantheon 4. 1975. 314-318.

Pignatti 1978 (1969) - Pignatti, T.: Giorgione, Milano, 1978 (1969)

Pignatti 1961 - Pignatti, T.: Per la recente fortuna critica di Giorgione, in Giorgione 1979. 37-40.

Pignatti 1979 - Pignatti, T.: The Golden Century of Venetian Painting, catalog in collaboration with DONAHUE, K., Los Angeles County Museum of Arts, 1979.

PignatTi 1990 - Pignatti, T.: Giorgione e Tiziano, in Tizian, Venezia-Washington, 1990

Places of Delight 1988-1989 - Places of Delight. The Pastoral Landscape, Washington, 1988

Procacci 1965 - Procacci, L. U.: Il carteggio di Marco Boschini con il Cardinale Leopoldo de Medici, Saggi e Memorie di Storia dell'Arte IV. 1965. 85-114.

Puncuh 1984 - Puncuh, D.: Collezionismo e commercio di quadri nella Genova sei-settecentesca, Rassegna degli Archivi di Stato XLIV. 1984. 164-218.

PupPi 1961 - PupPI, L.: Une ancienne copie du «Cristo e il manigoldo» de Giorgione au Musée des Beaux Arts, Bulletin de Musée Hongrois des Beaux Arts 18. 1961. 39-49.

RAMBAUd 1971 - Documents du Minutier central concernant l'histoire de l'art, 1700-1750, ed. Rambaud, M. Paris, 1971.

Rava 1920 - RaVA, A.: Il camerino delle anticaglie di Gabriele Vendramin, Nuovo Archivio Veneto XXXIX. 1920. 155-181.

Reitlinger 1961 - Reituinger, G.: The Economics of Taste, London, 1961.

RICHARDSON 1960 - RicHARDSON, E. P.: Archives of American Art. Records of art collectors and dealers: I. Miner K. Kellog, The Art Quarterly XXIII. 1960, 271-280.

Richter 1932 - Richter, G. M.: A Clue to Giorgione's Late Style, The Burlington Magazine LX. 1932. 122-125 + $128-132$.
Richter 1937 - Richter, G. M.: Girogione da Castelfranco, Called Giorgione, Chicago, 1937.

Richter 1939 - Richter, G. M.: Christ Carrying the Cross by Giovanni Bellini, The Burlington Magazine LXXV. 1939. 94-97.

Richter 1942 - Richter, G. M.: Lost and Rediscovered Works by Giorgione I-II, Art in America XXX. 1942. 141-157, 211-224.

Richter-Batz 1942 - Richter, G. M. - Batz Z, G. De: Giorgione and His Circle, Johns Hopkins University, Baltimore, 1942.

Ridolfi 1648 (1914) - Ridolfi, C.: Le maraviglie dell arte, Venezia, 1648, ed. Hadeln, D. V., Berlin, 1914.

RingBom 1965 - RingBOM, S.: Icon to Narrative, the Rise of the Dramatic Close-up in Fifteenth-Century Devotional Painting, ÅBO Akademi, Åbo, 1965.

ROBERTSON 1978 - ROBERTSON, G.: Giorgione and Leonardo, in Giorgione 1979. 195-199.

Rosetti 1780 - Rosetti, G.: Descrizione delle pitture, sculture ed architetture di Padova, Padova, 1780.

RYlands 1988 - Rylands, P.: Palma il Vecchio, l'opera completa, Milano, 1988.

SaArinen 1958 - SaArinen, A. B.: The Proud Possessors. The Lives, Times and Tastes of some Adventurous American Art Collectors, New York, 1958.

Samuels 1979 - Samuels, E.: Bernard Berenson. The Making of a Connoisseur, Cambridge-London, 1979.

SAmUEls 1987 - SAmUELS, E.: Bernard Berenson. The Making of a Legend, Cambridge, 1987.

San Diego 1960 - The Fine Arts Gallery of San Diego. Catalogue. A Selective Listing of All the Collections of the Fine Arts Society, The Fine Arts Society of San Diego, 1960.

SAVINI BRANCA 1964 - Savini Branca, S.: Il collezionismo veneziano nel 600, Padova, 1964.

SCHÄFFER 1910 - SCHÄFFER, E.: Giorgiones Landschaft mit den 'Drei Philosophen', Monatshefte für Kunstwissenschaft III. 8/9. 1910. 340-345.

Schuppach 1978 - Schuppach, W.: Doctor Parma's? Medical Macaronic Poem by Bartolotti, Pictures by Giorgione and Titian, The Journal of the Warburg Institute XLI. 1978. 147-164.

SCHWARTz 1967 - Schwartz, A.: Museum. The Story of American Treasure Houses, New York, 1967.

SECREST 1979 - SECREST, M.: Being Bernard Berenson, New York, 1979.

SEgarizzi 1914 - Segarizzi, A.: Una lotteria di quadri nel secolò XVII, Archivio Veneto XXXII. 1914. 172-187.

Settis 1982 - Settis, S.: Giorgiones Gewitter, Auftraggeber und verborgenes Sujet eines Bildes in der Renaissance, Berlin, 1982.

SHAKeShaft 1985 - Shakeshaft, P.: 'To Much Bewiched with Thoes Intysing Things': The Letters of James, Third Marquis Hamilton and Basil, Viscount Feilding, concerning Collecting in Venice 1635-1639, in The Burlington Magazine CXXVIII. 1985. $78+114-134$.

SHAPLEY 1968 - SHAPLEY, F. R.: Paintings from the Samuel $H$. Kress Collection. Italian Schools. XV.-XVI. Century, London, 1968

Shapley 1979 - Shapley, F. R.: Catalogue of the Italian Paintings, Washington, National Gallery, Washington, 1979. 
SheArman 1983 - SheARMAn, J.: The Early Italian Pictures in the Collection of Her Majesty the Queen, Cambridge, 1983.

STEARNS 1901 (1969) - SteARNS, F. P.: Four Great Venetians. An account of Giorgione, Titian, Tintoretto, Veronese, New York, 1901 (1969).

Stedman Sheard 1992 - Stedman Sheard, W.: Giorgione's Portrait Inventions c. 1500: Transfixing the Viewer (with observations on some Florentine antecedents), in Reconsidering the Renaissance, ed. DI CESARE, M., Binghamton N.Y., 1992. 141-176.

Stedman Sheard-Paoletti 1978 - Stedman Sheard, W. Paoletti, J. T.: Collaboration in Italian Renaissance Art, New Haven - London, 1978.

Steegmüller 1951 - Steegmüller, F.: The Two Lives of James Jackson Jarves, New Haven, 1951.

SUIDA 1933 - SuIDA, W.: Titian, Zürich, 1933.

SuIDA 1956 - SuIDA, W. E.: Giorgione in American Museums, The Art Quarterly XIX. 1956. 145-152.

Suter 1928/29 - Suter, K. F.: Giorgiones "Testa del Pastorello che tiene in man un frutto", Zeitschrift für bildende Kunst 62. 1928/29. VIII. 169-173.

TAYLOR 1948 - TAYLOR, F. H.: The Taste of Angels - A History of Art Collecting from Ramses to Napoleon, Boston, 1948.

TEMPESTINI 1978 - Tempestini, A.: Scitti di Storia dell'Arte in onore di Federico Zeri, Milano, 1978.

Tharp 1965 - Thare, L. H.: Mrs. Jack, Boston, 1965.

The Genius of Venice 1500-1600, eds. Martineau, J. - Hope, Ch., London: The Royal Academy of Art, 1983.

Tietze 1935 - TIETZE, H.: Meisterwerke europäischer Malerei in Amerika, Wien, 1935.

Tietze 1936 - Tietze, H.: Tizian, Leben und Werk, Wien, 1936.

Tietze-Conrat 1948 - Tietze-Conrat, E.: An Unpublished Madonna by Giovanni Bellini and the Problem of Replicas in his Shop, Gazette des Beaux Arts XXXIII. 1948. 379-382.

Tietze - Tietze-Conrat 1949 - Tietze, H. - Tietze-Conrat, E.: The Allendale Nativity in the National Gallery, The Art Bulletin XXXI. 1949. 11-20.

Titian, Prince of Painters, eds. Biadene, S. - Yakush, M., exhibition catalogue Venezia-Washington, München New York, 1990-1991.

Titien 1993 - Le siècle de Titien, Louvre, Paris, 1993.

Troche 1932 - Troche, G.: Giovanni Cariani als Bildnismaler, Pantheon IX. 1932. 1-7.
TsCHMELITSCH 1975 - TsChMELiTSCH, G.: Zorzo, genannt Giorgione. Der Genius und sein Bannkreis, Wien, 1975.

Tsuji 1979 - TsujI, Sh.: La « nocte » di Giorgione, in Giorgione 1979. 293-297.

Valcanover-Cagli 1969 - Valcanover, F. - Cagli, C.: L'opera completa di Tiziano, Milano, 1969

VASARI 1568 (1550) - VASARI, G.: Le vite de'più ecellenti pittori, scultori ed architetti , ed. MiLANESI, G., I-IX, Firenze, 1878-1885.

Venetian Painting, The Institute of Arts, Detroit, 1941.

Venetian Painting from the Fifteenth through the Eighteenth Century, Legion d'Honneur, San Francisco, 1938.

Venturi 1895 - VentuRi, L.: Il libro dei conto do Lorenzo Lotto, Gallerie Nazionali Italiane, 1895.

Venturi 1913 - Venturi, L.: Giorgione e Giorgionismo, Milano, 1913.

Venturi 1928 - Venturi, L.: Storia dell' arte iltaliana. La pittura del cinquecento, IX/3, Milano, 1928.

Venturi 1937 - Venturi, L.: Pitture italiane in America, Milano, 1937.

Venturi 1954 - Venturi, L.: Giorgione, Roma, 1954.

VerheYEn 1990 - Verheyen, E.: Veronese in America. Preliminary Observations, in Paolo Veronese: Fortuna Critica und künstlerisches Nachleben, eds. Meyer zUR CAPELlen, J. - Roeck, B., Centro Tedesco di Studi Veneziani, Sigmaringen, 1990. (Studi. Schriftenreihe des Deutschen Studienzentrums in Venedig. Band 8) 135-146.

WALKer 1969 - WAlker, J.: Self-Portrait with Donors. Confessions of an Art Collector, Boston-Toronto, 1969.

Waterhourse 1952 - Waterhourse, E. K.: Paintings from Venice for Seventeenth Century Europe: Some Records of a Forgotten Transaction, Italian Studies VII. 1952. 1-23.

Wethey 1969 - Wethey, H.: Titian, The Religious Paintings I., London, 1969.

Wethey 1972 - Wethey, H.: Titian, The Portraits II., London, 1972

YRIARTE 1882 - YRIARTE, Ch.: A propos d'un tableau attribué au Giorgione, Exposition des Old Masters, a Londres, L'Art 8. 1882. II. 61-66.

Zampetti 1955 - Zampetti, P.: Girogione i Giorgioneschi, Venezia, Palazzo Ducale, 1955

ZAMPETTI 1968 - ZAMPETTI, P.: L'opera completa di Giorgione, Milano, 1968

Zeri-Gardner 1973 - Zeri, F. - GARDNER, E. E.: Italian Paintings. A Catalogue of the Collection of the Metropolitan Museum of Art. Venetian School. The Metropolitan Museum of Art, New York, 1973.

\section{NOTES}

\footnotetext{
${ }^{1}$ It was Lanier Graham, the president of the World Art Press and Institute for Aesthetic Development, who called upon Klára Garas in 1993 to write about the paintings by Giorgione preserved in America. The manuscript was completed (the author wrote it in English), but probably owing to the change of the publishing house's choice of subject it has been never published. The author passed the article to the Acta Historiae Artium shortly before her death (26 June 2017), and it is published now with small technical amendments. Where no attribution was given by the author, that of Terisio Pignatti - Pignatti 1978 (1969) - was used.
}

Thanks are due to Ágnes Körber, Gabriella Sárváry and Vilmos Tátrai for their help during the editing works.

2 Brown 1983. See also VerHeyen 1990, 135.

${ }^{3}$ BROWN 1983, 135

${ }^{4}$ Della Lena 1967

${ }^{5}$ London, National Gallery, No. $269,39 \times 26 \mathrm{~cm}$. The sales catalogue of West (London, Christie's, 1820 June No. 62) mentions that he permitted it to be copied by its pupils several times.

${ }^{6}$ JARVES 1861, 33-38.

7 STEEGMÜLLER 1951. 
${ }^{8}$ New Haven, Yale University Gallery, No. 1871-1895, panel, $36.6 \times 79.4 \mathrm{~cm}$. In a letter addressed to Charles E. Norton from Florence in August, 1859, Jarves says "Giorgione - wonderful in color - a Circumcision". See also Italian Primitives 1972

${ }^{9}$ STEEGMÜller 1951, 173 states "Nothing is known of the Parisian Giorgiones", but the Chronique 1866, 66, and YRIARTE 1882, 61, reporting on it accurately, makes an identification possible. The painting was exhibited in London on several occasions (1881, 1912, Burlington House) as by Giorgione.

10 Pignatti 1975 , canvas, $49 \times 77$, last sold at Sotheby's 1979 July 14, No. 14.

${ }^{11}$ Miner K. Kellog bought his paintings partly in Paris (1855), and Europe (until 1865). See the catalogue of his collection: RICHARDSON 1960.

12 CARTER 1925; THARP 1965.

13 Samuels 1979, 248; Samuels 1987, 31; Hadley 1987, 60-72. See also Brown 1979.

${ }^{14}$ New York, Metropolitan Museum, Nr.14.40.640, canvas, $50.2 \times 45.1 \mathrm{~cm}$. Bequest of Benjamin Altman. See ZerIGARDNER 1973, 74 (with complete list of references and provenance). See also SeCREST 1979, 254, and HASKell 1987, 199.

${ }^{15}$ New York, Frick Collection, No. 15.1.116, canvas, $82.3 \times 71.1 \mathrm{~cm}$. See Frick Collection 1968. 251-255; COLETTI 1955, 62. as Giorgione.

16 GIMPEL 1966, 66 remarks on it: "At Joe's (Duveen's) I saw the Titian, it is not large, a portrait of a man in front of a balustrade like that of Schiavone. He has a beard and forceful cruel black eyes. The resolute fist rests on a book. Giorgione must have had a hand in it as with La Schiavona."

17 Pasadena, Norton Simon Museum, canvas, $69 \times 52 \mathrm{~cm}$, earlier in Vienna, Eissler collection (1922) as Titian. See PIGNATTI 1979.

18 BeHRMAn 1980, 1

19 BeHRMAN 1980, 125-128.

${ }^{20}$ WALKer 1969, 119; FinLEy 1973.

${ }^{21}$ SHAPLEY 1968. Among those connected in the past with Giorgione we can mention the Portrait of a Young Man now ascribed to Pordenone, (from Onigo collection, Treviso) in the De Young Memorial Museum San Francisco; Triumph of Julius Ceasar by Palma at Coral Gable; Adoration, now ascribed to Titian in the North Carolina Museum of Art, Raleigh; Basaiti's Portrait of a Warrior in the Fogg Art Museum, Cambridge, etc.

22 Phillips 1937; Phillips 1970.

23 RiCHTER-BATZ 1942.

${ }^{24}$ Summaries on Giorgione's paintings in the USA: SUIDA 1956; FREDERIKSEN-ZERI 1972 (Adoration of the Shepherds and Venus with Cupid, National Gallery, Washington; Terris Portrait, San Diego; Allegory of Time, Phillips Memorial Museum, Washington; Paris on Mount Ida, Princeton; "Appeal", Detroit).

${ }^{25}$ Wood, $24.1 \times 20.6 \mathrm{~cm}, 1942$, Colonel Strode Jackson, Oxford, Knoedler's Gallery, New York. SuTER 1928/29, 169; Pignatti 1975, 314; Berenbaum 1977, 22; Pignatti 1979.

${ }^{26}$ We might add one hitherto unnoticed data to the history of this bust. In the inventory of Prince Maffeo Barberini in Rome, 1686, a small panel painting is quoted as "Giovinetto col lamano sopra la pallad'oro". See Lavin 1975, 418. It might be identical with the painting in the USA, or else, with its feebler version in the museum of Aix-en-Provence.
${ }^{27}$ Canvas, $77.7 \times 64 \mathrm{~cm}$, earlier in Polcenigo Collection, Venice; P. M. Bardi, New York; G. Milani, Brazil. The X-rays show the figure of a shepherd crosswise to the present composition. See GrabSKI 1990, 130. Nr. 2. See also PAllucCHInI 1959-1960, 39.

${ }^{28}$ The painting mentioned but not sold to Leopoldo di Medici as by Giorgione: "Un Christo ... aintera (?) alnaturale et un angeloche lo rimir a piangendo largo quarte lo alto 6 cca" $(102 \times 170 \mathrm{~cm}$.) In an inventory in Venice (unknown proprietor) 1672 "Un Christo alla sepoltura copia di Zorzon" is mentioned (LEVI 1900. II. 53.) For a possible link with Giorgione's Pietà see ProCACCI 1965.

29 See GraHAM 1993-1994.

30 BerENSON 1901, 137; SteARNS 1901 (1969), 26.

${ }^{31}$ Michiel 1888, 78, 80, 88, 106.

32 VASARI 1568 (1550), IV. 13.

33 WATERHOURSE 1952; GARAS 1968; SHAKESHAFT 1985.

${ }^{34}$ According to HaSkell 1981, 585 there were about 40 paintings attributed to Giorgione in the sixteenth century, about 250 in the seventeenth and several thousands in the eighteenth century. See also GARAS 1964, 57; 1965, 33; $1966,69$.

35 ProCACCI 1965, 85.

${ }^{36}$ Beside a number of works earlier ascribed to Giorgione and mentioned in this essay (the so called Borgherini Double Portrait, in the National Gallery, Washington; the Circumcision, at the Yale; the Adoration in the Museum of Raleigh; the Altman and Frick Portraits, in New York, etc.), we should mention here also a few others in the United States with traditional attributions to the master. There is the Appeal in the Detroit Institute of Art named as by Giorgione, Titian and Sebastiano del Piombo in the seventeenth century (by Sebastiano del Piombo?), the Venus and Mars in the Brooklyn Museum, New York (inscribed Giorgione on the reverse) ascribed now to Palma, a Man in Armour in the Wadsworth Athenaeum, Hartford as by Giorgione in the eighteenth and possibly the sixteenth century (by Sebastiano del Piombo). The Bust of a Woman (Violante) Museum of Fine Arts in Houston, the two other versions ascribed in the seventeenth century to Giorgione (Budapest Museum of Fine Arts and Modena Galleria, now as Cariani), etc. Others have turned up in private collections and at sales and exhibitions. There, identification with paintings attributed to Giorgione in the past centuries is extremely difficult, if not impossible, as they are works, mostly existing in several versions.

${ }^{37}$ For the practice of replicas see TIETZE-CONRAT 1948 , 379.

38 ShAPLEY 1979, 208. The X-ray and infrared photos show a number of changes especially in the landscape background. See also Mucchi 1978, 31.

39 SHEARMAN 1983, 68 (Ferrarese School).

40 Goldberg 1983, 39, 73, 276.

${ }^{41}$ Catalogue des tableaux du cabinet de feu de la Châtaigneraie, Paris, 1732, Inventaire d' après décès de Charles Jean Baptiste Fleuriau, Comte de Morville: Rambaud 1971, I. 571.

42 For Albano's letter in extenso see Pignatti 1969, 160.

${ }^{43}$ Tietze - Tietze-Conrat 1949; Gibbons 1978, 23; Tsuji 1979, 293. In opposition to the interpretation of "Nocte" as a night piece, BALDASS-HEINZ 1969, and others hold the assumption that it simply means the "Holy Night," the Birth of Christ.

${ }^{44}$ GARAS 1967, 39; 1968, 181. 
${ }^{45}$ Michiel 1888, 87. The Three Philosophers in Vienna, Kunsthistorisches Museum, the Finding of Moses until mideighteenth century in Vienna, now lost.

${ }^{46}$ Michiel 1888, 78, 80. We know also from Lorenzo Lotto's personal accounts, the Libro dei conti, that the painter had repeated several of his own compositions (for instance the Nativity) for different customers. This was a frequent practice also with Titian, he wanted to borrow for instance his Christ from the Duchess of Urbino "to make another of it for the pope." The four paintings with the Madonna cheva in Egitto by Gerolamo Savoldo mentioned in the will of the Venetian poet and patrician, Pietro Conarini (1502-1555) should be perhaps also mentioned in this context.

${ }^{47} \mathrm{~A}$ further painting with the Adoration of the Shepherds earlier ascribed to Giorgione is in the W. Rockhill Nelson Gallery in Kansas City, USA. In the Duke of Leuchtenberg collection, Munich, 1845, and then in St. Petersburg, later in the market in London and New York, it went under the name of Giorgione. It exists in several versions (London, National Gallery, etc.) and is now ascribed to Giovanni Cariani or Giovanni da Asolo.

${ }^{48}$ For the different opinions in detail see SHAPLEY 1979, 209; see also ANDERSON 1979A, 87.

${ }^{49}$ For the complicated history of Giovanni Bellini's Presepio see FleTCHER 1971, 703.

50 Shapley 1979, 211; Titien 1993, 295. The infrared photo shows slight alterations in the figures. Characteristic underdrawings like some in other works by Giorgione, for instance The Adoration of the Magi (London, National Gallery). See HORnig 1980, 48.

${ }^{51}$ Hoet-Terwesten 1752-1770. II. 340. The reference applies equally to_the little St. Petersburg-Raleigh type of paintings (see note 54)

52 VASARI 1568 (1550), IV. 93.: “...Lavoro in Venezia nel suo principio multi quadri di Nostra Donna...".

53 The half figure Madonna with Child quoted in the inventory of Gabriele Vendramin's camerino (1567-1569) as work by Giorgione passed with twenty other paintings from the collection of Nicolo Renieri to the Durazzo in Genova. Ascribed at that time also to Titian (1670), it could not be traced like the rest of the lot passing as inheritance to the Galleria di Palazzo Rosso in Genova. See Puncun 1984, 213.

${ }^{54}$ Raleigh, North Carolina Museum of Art, wood, $19.1 \times 16.2 \mathrm{~cm}$, inscribed on the back: "Zorzon" (?) Kress Collection. Earlier with F. Mont, New York and Count Contini Bonacossi, Florence; St. Petersburg, the Hermitage, wood, $48.9 \times 40 \mathrm{~cm}$, from the Castle Gatschine. In 1740 in the collection of Pierre Crozat, Paris as by Giorgione. It is a similar composition with a different landscape and background figures on the engraving of the Nativity by the master FN around 1515, see Hind 1948, II. Vol. V. 247, 830. The kneeling Madonna and the Child are similar to the same figures in the Allendale Adoration, the setting seems to be inspired by Dürer.

${ }^{55}$ For the different opinions and the latest bibliography see: Titien 1993, 295.

56 ANDERSON 1985, 105, 115, 136.

${ }^{57}$ RiCHTER 1937, 234; RiCHTER 1939, 95; HEINEMANN 1962, I. 151, II. Ab. 91, 258.261.

58 MiCHIEL 1888, 68. "El quadric del Christo cun la croce in spalla insino(?) alleapalle(?)fo de mano de ZuanBellino". The Bellini attribution of the Toledo painting has been re- jected lately by GOFFEN 1989, 85, 301, while the Boston version is considered as by Bellini and assistants, not Giorgione.

${ }^{59}$ Hendy 1931, 162.

${ }^{60}$ See the different opinions and detailed bibliography with Pignatti 1978 (1969), 96, and lately Tempestini 1978, 315, 320 on the Boston Christ: "ormai quasi universalmente riconosciuto come opera del Giorgione".

61 See Bollettino del Museo Civico di Padova, 1980 LXIX, 109; Rosetti 1780, 119; Brandolese 1797, 114; CrowCavalCaselle 1871, VI. 198.

62 Ringbom 1965.

${ }^{63}$ Concerning S. Rocco Christ and its relation to the Bellinesque-Giorgionesque type, see Pignatti 1978 (1969), 115. See also Pietro C. Marani and Giovanna Nepi Sciré in Leonardo E Venezia 1992, 344-353, Nos 69-71, as well as PuppI 1961, 39, and ANDERSON 1977, 203.

${ }^{64}$ Phillips Collection 1981-1982.

65 Sammlung Wilhelm Koller, bei A, Posonyi, 5. February 1872, Wien, Nr. 21.

${ }^{66}$ Ridolfi 1648 (1914), I. 95, 98

${ }^{67}$ BERENSON 1957. I., 86: "with Giorgionesque furniture paintings"; Pignatti 1978 (1969), 146: with "Opere attribuite"; BANZATO 1988, 62. No. 36-37.

${ }^{68}$ Gentili 1988, 48: as "Suonatrice e vecchio con clessidra". There is a somewhat similar subject on a circular panel in the Museo Querini Stampal in Venice on the verso of a Vulcanus a Cupid painting: it shows a standing youth playing the violin in a landscape, an old man sitting before him. The music instrument in the Washington picture, a "violin di braccio" looks very much like one of the instruments painted in the fresco on Casa Pellizari in Castelfranco.

${ }^{69}$ Borenius 1923. See also Pignatti 1978 (1969), figs. 59-74.

70 One might mention in connection with these furniture paintings a further example in the USA, the Allegory from the Campbell Blaffer Found in Houston, (once in the collection of F. Cook in Richmond) which was probably a cover (timpan) of a painting, eventually a portrait. See Places of Delight 1988-1989, Nr. 10, referred to as "circle of Giorgione".

${ }^{71}$ Bibliography see: PignatTi 1978 (1969), 146, as well as Phillips Collection 1981-1982.

72 SHAPLEY 1979, as by "Follower of Giorgione".

${ }^{73}$ Princeton Art Museum, Frank Jewett Mather collection, earlier Collection Clyde Fitch. Wood, $38 \times 57 \mathrm{~cm}$. See PignATti 1978 (1969), 136.

${ }^{74}$ Until now there has been no systematic survey of all the so called Giorgionesque furniture paintings published or mentioned. They seem to be of different type and origin, some of them belonging eventually to caskets, cassoni, decoration of beds, cupboards, functioning as covers of portraits, etc.

75 The inscription on the reverse of the original canvas - now covered by the lining canvas - is not easy to read or to interpret; it seems to date from the eighteenth century. The name "Carlo Fabrini" could not be identified, but connection with Giovanni Francesco Fabrini (1516-1580), the author of grammatical works and classic translation has been suggested. He was the Fabrini present as partner in the discussion on art of Lodovico Dolce - see DolCE 1557 (1891) - and was active in Venice in the first half of the sixteenth century.

${ }^{76}$ See GraHAm 1993-1994, and earlier editions with detailed report on technical analysis, provenance attribution and subject. 
77 See Graham 1993-1994, 75, 25-33, Physical Analysis 1, Conservation report by J. Bertalan, done in Birmingham; Physical Analysis 2, Pigment report, a scientific study by W. C. McCrone, done in Chicago. See also McCrone 1994, 111-119.

78 See note 75, 48-76 historical research and documents on provenance and earlier owners, the Leigh (Lee) family, by W. Cumins, England. John Legh/Leigh, born about 14901500, was in Venice and Rome in service of the King of England in November-December 1538. He seems to have met there Cardinal Reginald Pole from England, who was portrayed by Sebastiano del Piombo, Giorgione's pupil (now in the Hermitage, St. Petersburg). As suggested by W. Cumins, John Le(i)gh might have acquired the painting by Giorgione of The Three Ages of Man with the assistance of the Cardinal, which went to England in the same year (i.e. in 1538).

79 See Lucco 1989, 112, where A. del Serras reports also on the reflectography investigation and the restoration. The "quarte" quoted in the inventories measures $17.08 \mathrm{~cm}$. For the Renieri inventories see CAMPORI 1870, 422; SEgARIZZI 1914, 172; SAVINI BRANCA 1964, 52, 91.

80 GARAS 1979; LUCCO 1989; BALLARIN 1993.

${ }^{81}$ RAVA 1920, 155.

82 ANDERSON 1979, 639.

83 See in this sense also HOLBERTON 1985-1986, 191.

${ }^{84}$ The identification of the Three Singers with the two separate half-figures in the Galleria Borghese, Rome, as suggested by Della Pergola 1955, 27, 111-113 cannot be accorded with the known facts and has been rejected by most of the critics. The same is valid for further identification proposed recently (Titien 1993) concerning the painting Samson Mocked which emerged from an Italian private collection and which shows three half-figures. Restoration has revealed lately that the central figure is holding the upper part of a lute, and thus, the painting cannot be interpreted as Three Busts Singing. The picture's different measurements confirm further that it can hardly be connected with the Samson Mocked by Giorgione, once in the collection of Nicolò Renieri.

${ }^{85} \mathrm{~A}$ painting representing three half-figures, a man, an old woman with a violin and a young man, quoted in the Medici inventories next to The Three Ages of Man (Nr. 235236) was in the collection of Andrea Vendramin, a relative who owned certain paintings from Gabriele Vendramin's camerino. See Borenius 1923, 16. Thought to be lost, this picture has now turned up in Siena, Palazzo della Provincia, coming from the Medici collection, Florence.

${ }^{86}$ Calendar of State Papers, Venice, 1617-1619, London, 1909 XV. 426 Nr. 684.

87 Scriptores Historiae Augustae. Vitae diversorum principum et tyrannorum a divo Hadriano usque ad Numerianum diversis compositae, ed. Manuzio, A., Venezia (1516, 1519, etc.). See also to this interpretation SCHÄFFER 1910, and GRAHAM 1993-1994, 83-96, on the Asolo connection, underlying the connections between Giorgione, the court of Asolo, Pietro Bembo and the trend of stoic philosophy.

88 Stendhal, Oeuvres completes, the relevant passage quoted by DÉDÉYAN 1981. 659, 696, without noticing the connection with the Pitti Three Ages.

${ }^{89}$ Washington, National Gallery of Art, Nr. 2674, canvas, $46.5 \times 59 \mathrm{~cm}$. X-rays show pentimenti, alterations made during the working process. See SHAPLEy 1979, 217. PHILLIPS
1937 suggested that the Borgherini Portrait might be identical with The Three Ages of Man in the Pitti. But as VASARI 1568 (1550), IV. 91 clearly speaks of only two heads in the picture, this identification cannot be accepted.

${ }^{90}$ Hampton Court Palace, Royal Collection, Inv. Nr. 144, canvas, $76 \times 99 \mathrm{~cm}$. Of its origin in the Reynst collection, formed before 1648 in Venice, see LOGAN 1979, 120 with detailed bibliography.

${ }^{91}$ For the different opinions and attributions see Titien, 1993, 309.

92 VASARI 1568 (1550), IV. 91.: “..e piacqueli il suono del liuto mirabilmente e tanto, che egli sonava e cantava nel suo tempo tanto divinamente, che egli era spesso per quello adoperato a diverse musiche e ragunate di persone nobili".

${ }^{93}$ For the interpretation of music in Italian Renaissance painting see among others: EGAN 1961, 184; EINSTEIN 1949; Hess 1955; MORASSI 1942 called The Three Ages of Man "un poetico solenzio", a sort of holy conversation without saints, HugELSHOFER 1971 named it "Memento Mori - Darstellung in sublimster Form". For GENTILI 1988 it is "la percorso della vita allegorizzato nel concerto vocale", for BALLARIN 1979 "motive neoplatonico nella musica".

${ }^{94}$ DOLCE 1557 (1891), 60

${ }^{95}$ Ridolfi 1648 (1914), I. 100. As Justi 1908, 358 already indicated, this compilation with symbols of human life allegedly by Giorgione in Genova must have inspired the young Anthonis van Dyck around 1622, when staying in Genova. He constructed using its motifs the painting The Four Ages now in the Musei Civici Vicenza (from the Mantua collection, 1665).

${ }^{96}$ See Newton in Graham 1993-1994, 19; Newton 1988; and also LuCCO, 1989, 14, 18.

${ }^{97}$ VASARI 1568 (1550), IV. 92.: "Aveva veduto Giorgione alcune cose di mano di Leonardo molto fumeggiate e cacciate, come si è detto terribilmente di scuro, e questa maniera gli paicque tanto, che mentre visse sempre ando dietro a quella, e nel colorito a olio la imita grandamente." LUCCO $1989,21$.

${ }^{98}$ See in this connection: Leonardo \& Venezia 1992; Pedretti 1979, 181; Robertson 1978, 195.

${ }^{99}$ For the conditions in choosing the subject, the material, etc. see the documents concerning the relations of Isabelle d'Este and Giovanni Bellini, in FLETCHER 1971, 703. They gave ample information on destination (bedroom, studio), on subject ("istoria o fabula antique", "cosa antique di bello significato"). There, we find information as well as on the choice and predilection of the painter ("una fantasia a suo modo") on the changing of the subject, on his free decision on material (canvas or wood), on prices and down payments.

100 Pater 1959 (1873), 92. See recently Fomiciova 1979, 159.

${ }^{101}$ For a detailed account on Giorgione's customers, see BAtTilotTI-Franco 1978, 58.

102 See Bibliography and ample enumeration with valuation in Pignatti 1978 (1969), 114. Le siècle de Tititen, 1993, 309-313.

${ }^{103}$ Brown 1992, 385. See also Ballarin $(1993,312)$ on the Pitti Three Ages of Man: "Ce tableau est l'un des chefsd'oeuvres de Giorgione et du nouveau siècle...".

${ }^{104}$ Later copies of The Three Ages of Man composition (Pitti) were in the collection of D. R. Grantham, Westcot, Dork- 
ing (England) sold at Sotheby's, London 15 June $1977 \mathrm{Nr}$. 31.With Claude L. Suttles, Atlanta (from St. Louis) 1959. The one mentioned in the literature (HeINEMANN 1962) with Hartfeldts in Antwerp was a totally different composition and a different subject.

105 San Diego 1960, 65; Titien, 1993, 337.

106 Galleria Borghese, Inv. Nr. 62, see Della Pergola 1955, 114.

107 Garas 1972. See also Hornig 1987, 231.

108 VASARI 1568 (1550), IV. 114.

${ }^{109}$ For the latest bibliography see PignatTi 1978 (1969), 69, 113; Titien 1993, 337.

110 A relation or identity between the so called Parma portrait by Titian in the Kunsthistorisches Museum of Vienna and the Terris Portrait as proposed by SCHUPPACH 1978 is by no means apparent or convincing. Some similarity might be detected on the other hand in the fanciful structure between the San Diego painting and the drawing after a Man's Bust "di Zorzon" 1627 in the collection of Andrea Vendramin in Venice. See BORENIUS 1923.

${ }^{111}$ Lomazzo 1584 (1973-1974, II. 372).

112 See also GARAS 1981.

113 SHAPLEY 1979, 213.

114 "...li ritratti Tiziano e Giorgione belle...", "Tiziano ritratto uomo Giorgione detto", etc. See the Ms. letters in Epistolario Moschini, Biblioteca Correr, Venezia, Catalogue of pictures by the late John Strange, Christie's March 1800 with five other works ascribed to Giorgione.

115 The X-ray report by Burroughs quoted by SHAPLEY 1979, 213; Mucchi 1978, 57. See also Pallucchini 1962, 234

116 Oxford, Ashmolean Museum, Nr. 177, panel $76 \times 60 \mathrm{~cm}$. Earl Cathcart, Christie's, London, 13 May 1949 lot 119; Duc de Tallard Sale, Paris, 1756 Nr. 88 as by Giorgione. See Pallucchini 1949, 178.

${ }^{117}$ For the covers (coperto, timpani, etc.) of portraits and paintings see for instance VENTURI 1895; ANDERSON 1979, 647. See also HADELN 1909.

118 For the different interpretations see especially: Cox 1913 , 115; GRUMMOND 1975, 346; GRAHAM 1993; BALLARIN 1993.

119 Broschini 1660, 308: "Ha de quela Virtù vivo un retrato / D'un Homo eccellentissima satura / Dove gariza insieme Arte, e Natura / E ogn' un che'l vede resta stupesato". The repeated statement that V V appears only on portraits is contradicted by the fact that it figures also in a Nativity (on the base of a column) in the Musei Civici di Treviso.
120 BERENSON 1901, 82.

${ }^{121}$ It was related to the so called Schiavona Portrait from the Cook collection, now National Gallery, London, accepted today as by Titian; with the so called Sansovino (a sculptor or antiquarian), once Brownlow collection; with the Budapest Broccardo Portrait, etc. For the portrait of Giorgione in general and the turning portrait as an invention by Giorgione see Anderson 1979B, 153; Pedretti 1979, 181; STEDMAN SHEARD 1992, 141.

122 VASARI 1568 (1550), VII. 428.

123 WETHEY 1972.

124 SHAPLEY 1979, 213 puts it tentatively as "Giorgione and Titian, attributed to" quoting in detail the different opinions. To W. Suida, H. Tietze, R. Pallucchini, A. Ballarin it was Titian, but F. Valcanover (VAlCANOVER-CaGLI 1969, 89) said that after the restoration by M. Modestini "... i caratteri giorgioneschi si rivelano come più probanti”. See also PIGNATTI 1990, 68.

125 See Francis 1956. See also Wethey 1972 as well as the Norton Simon Museum 1980.

126 BALDASS 1929, 91; TROCHE 1932, 1; RICHTER 1932, 122.

127 In Early Venetian 1895, 1912, 58. No. 60 of the so called Malatesta Rimini painting it is written that the woman's head is of "the same type of features" as the Female Head owned by Sir Alexander Henderson, which was earlier in the William Graham and the Earl of Malmesbury collection. At the W. Graham sale in 1886 it was attributed to Titian. As Alexander Henderson was First Baronet Faringdon at Buscot Park, the painting in question must be the Female Bust at Buscot Park, reproduced as a copy after Sebastiano del Piombo. See LuCCO-VolpI 1980, 91.

${ }^{128}$ For the various interpretations see HeLD 1961, 201; Wethey 1972, 159; Pedrocco 1990, 81.

${ }^{129}$ A picture of a Courtesan ascribed to Giorgione was offered for sale by a Brussels art dealer in 1644 in Antwerp, but as nothing is known about its future, and as there are several items of this kind in old inventories, it is almost impossible to identify it.

130 See Richter 1937, 237; Pignatti 1978 (1969), 150, C. 9. There was "a beautiful female with a wreath of myrtle looking round with an expression of determination" praised by $G$. Waagen in the London collection of Edmund Phipps, a hitherto unidentified picture. See Art Treasures 1854, II. 227. 131 See Bibliography.

${ }^{132}$ All illustration sare from the author's personal archive. 